\title{
Development of a Rhesus macaque engineered heart muscle model from pluripotent stem cells
}

\section{Doctoral Dissertation}

In partial fulfillment of the requirements for the degree

"Doctor rerum naturalium (Dr. rer. nat.)"

in the Molecular Medicine Study Program

at the Georg-August University Göttingen

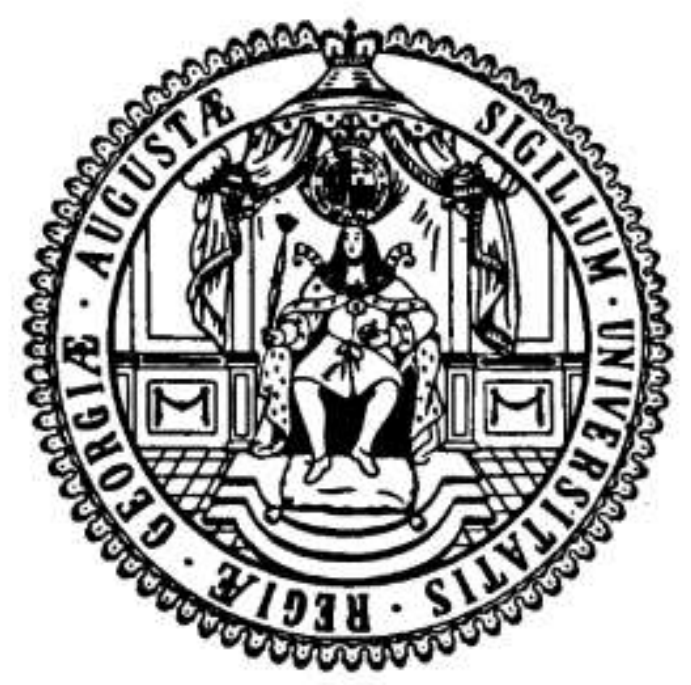

Submitted by

Brian T. Golat, MSc

born in Michigan, United States of America

Göttingen 2017 


\section{Thesis Committee}

Prof. Dr. med Wolfram-Hubertus Zimmermann

(Institute of Pharmacology and Toxicology)

Prof. Dr. Rüdiger Behr

(Leibniz-Institute for Primate Research, Degenerative Diseases,)

Prof. Dr. Lutz Walter

(Leibniz-Institute for Primate Research, Primate Genetics)

\section{Members of the Examination Board}

Prof. Dr. med Wolfram-Hubertus Zimmermann

(Institute of Pharmacology and Toxicology, UMG Göttingen)

Prof. Dr. Rüdiger Behr

(Leibniz-Institute for Primate Research, Degenerative Diseases)

Prof. Dr. Lutz Walter

(Primate Genetics, German Primate Center, Leibniz-Institute for Primate Research)

Prof. Dr. Ralf Dressel

(Department of Cellular and Molecular Immunology)

Prof. Dr. Stefan Luther

(Max Planck Institute for Dynamics and Self-Organization, Biomedical Physics,)

Prof. Dr. Steven Johnsen

(Department of Translational Cancer Research)

Date of examination: May 15, 2017 
AFFIDAVIT

Here I declare that my doctoral dissertation entitled:

"Development of a Rhesus macaque engineered heart muscle model from pluripotent stem cells"

has been written independently with no other sources and aids than quoted.

Brian T. Golat, MSc.

Göttingen, April 2017 


\section{List of poster presentations:}

Brian Golat, Arne Krahn, Wolfram-Hubertus Zimmermann (2015) Development of a scalable suspension and cardiac differentiation culture of Rhesus macaque induced pluripotent stem cells for use in engineered heart muscle. Young DZHK Symposium, Brandenburg, Germany.

Brian Golat, Arne Krahn, Wolfram-Hubertus Zimmermann (2015) Engineered Heart Muscle from Rhesus Macaque Induced Pluripotent Stem Cell-Derived Cardiomyocytes. DGK Herbsttagung, Berlin, Germany. 3. Prize Hans-Jürgen-BretschneiderPosterpreis des Basic Science Meetings.

Brian Golat, Malte Tiburcy, Rüdiger Behr, Wolfram-Hubertus Zimmermann (2016) Comparative Analysis of Rhesus Macaque Stem Cells for use in Cardiac Tissue Engineering. DGK Herztage 2016, Berlin, Germany. 


\section{Table of Contents}

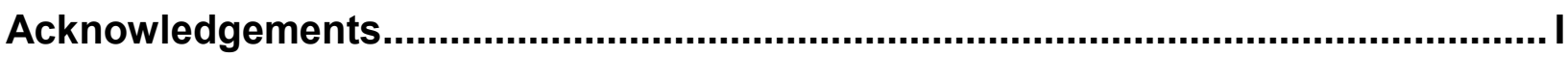

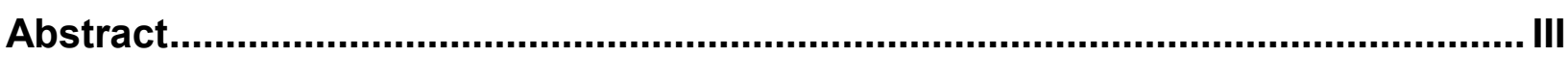

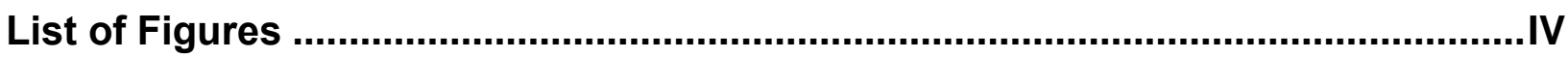

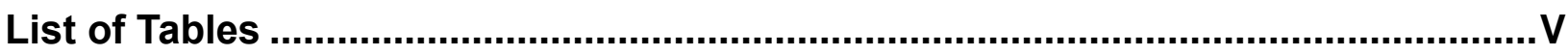

Abbreviations

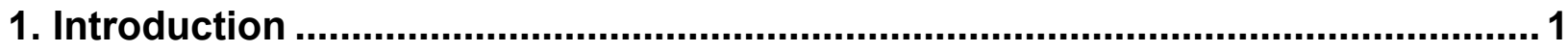

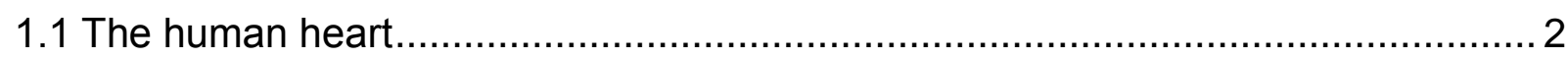

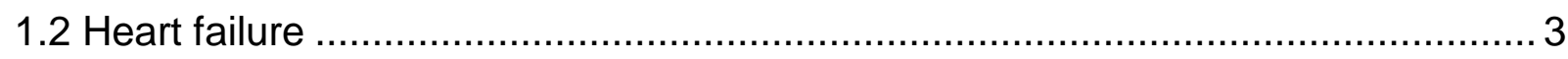

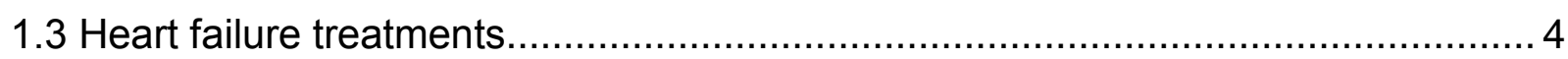

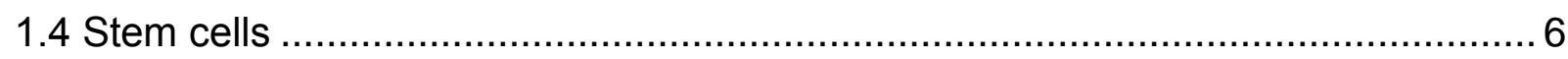

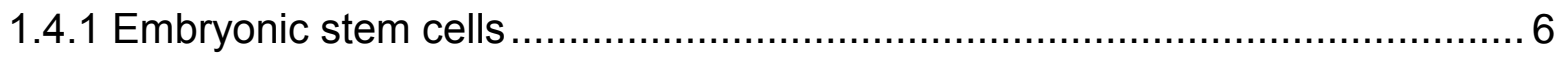

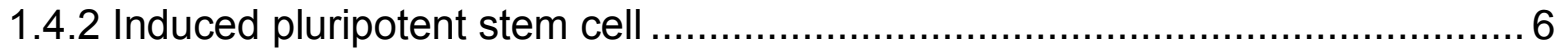

1.4.3 Parthenogenetic stem cells ..................................................................

1.4.3.1 Parthenote zygosity $\quad 8$

1.5 Directed cardiomyocyte differentiation ...................................................... 11

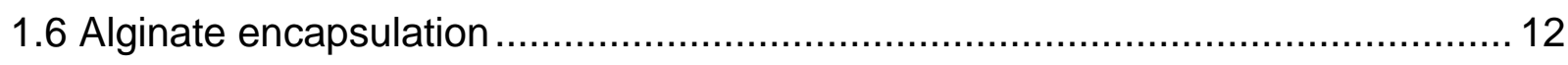

1.7 Engineering of heart muscle ......................................................................... 13

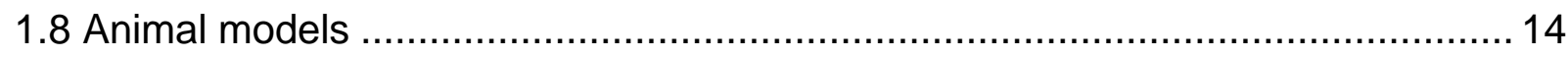

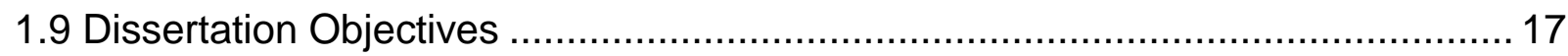

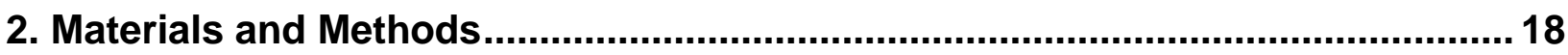

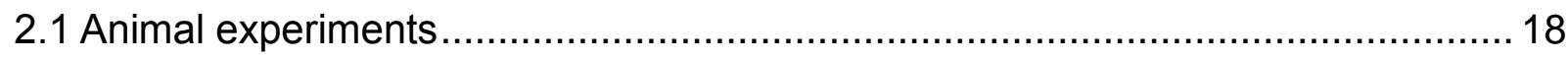

2.1.1 Superovulation of Rhesus Macaque (Macaca mulatta) .............................. 18

2.1.2 Collection of oocytes via follicle aspiration.............................................. 19

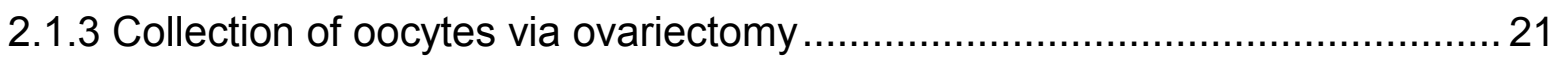

2.1.4 Collection of oocytes via necropsy..................................................... 21

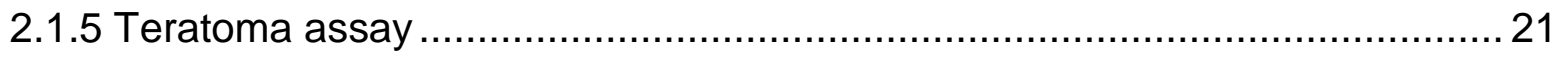

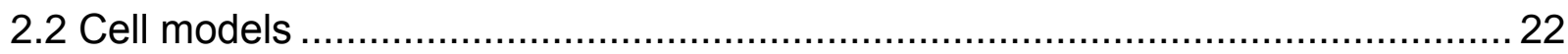

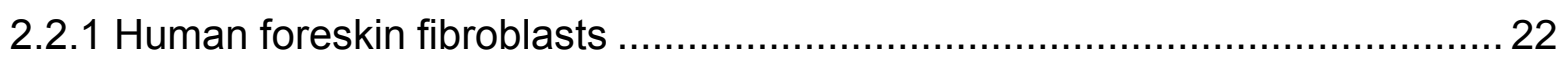

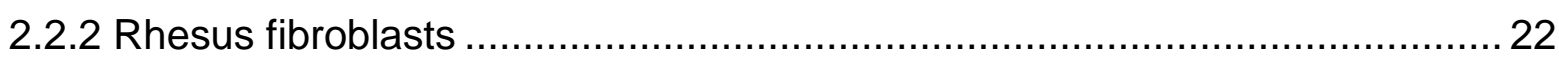

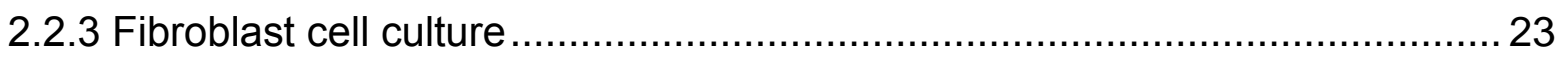

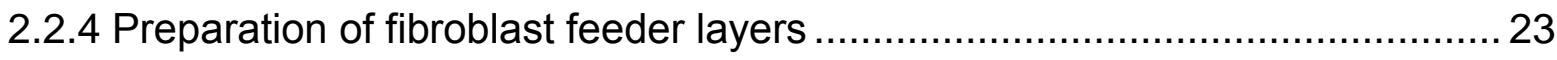

2.2.5 Preparation of Rhesus fibroblasts for engineered heart muscle .................. 24 
2.2.6 In vitro maturation of Rhesus oocytes............................................... 25

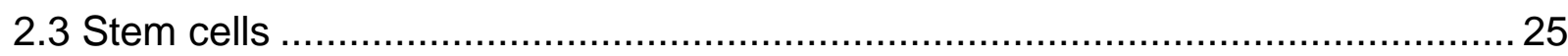

2.3.1 Rhesus macaque parthenogenetic stem cells .................................... 25

2.3.2 Rhesus Induced Pluripotent Stem Cell line $\mathrm{C} 1$..................................... 28

2.3.3 Rhesus Induced Pluripotent Stem Cell line 43110-4 ............................... 28

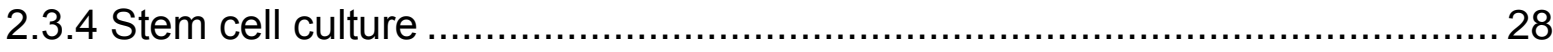

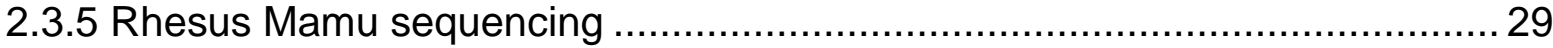

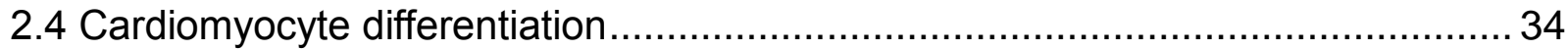

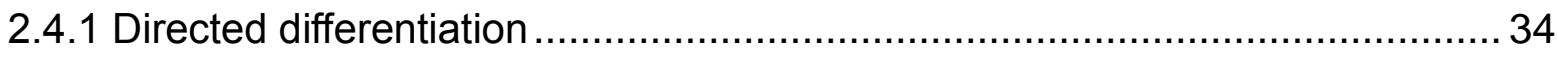

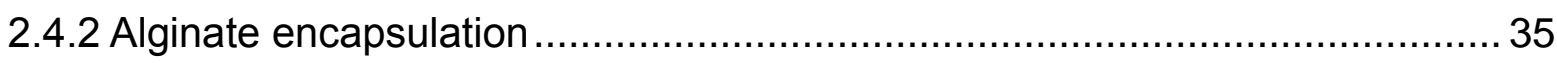

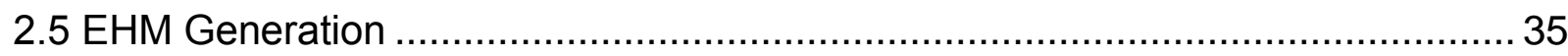

2.5.1 Construction of EHM casting molds and dynamic stretchers ...................... 35

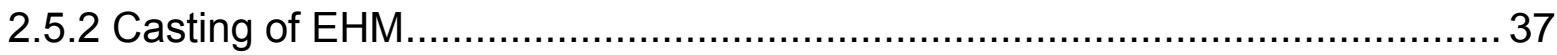

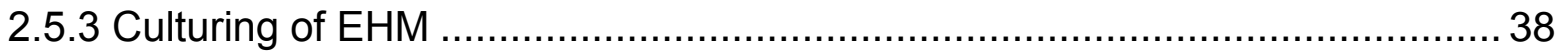

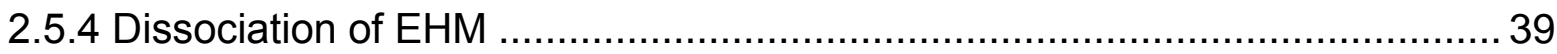

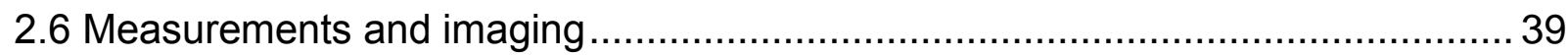

2.6.1 Cell count and size measurements................................................ 39

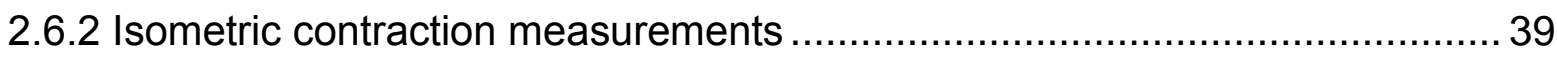

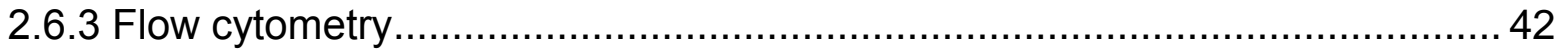

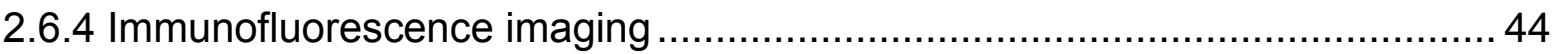

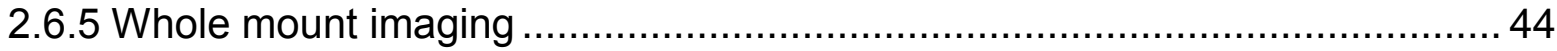

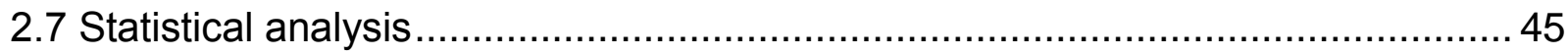

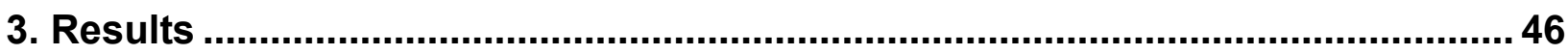

3.1 Encapsulation of Lenti-iPS cells in an alginate:gelatin hydrogel ..................... 46

3.2 Directed differentiation of alginate encapsulated Rhesus Lenti-iPS cells in

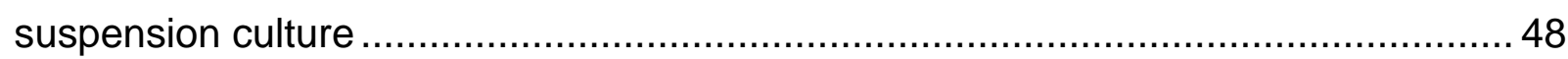

3.3 Directed differentiation of Rhesus Sendai iPS cells in monolayer culture ............50

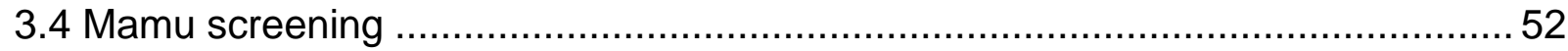

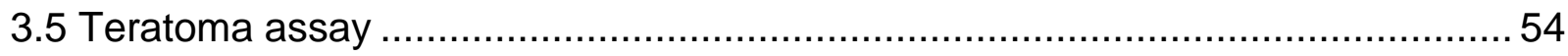

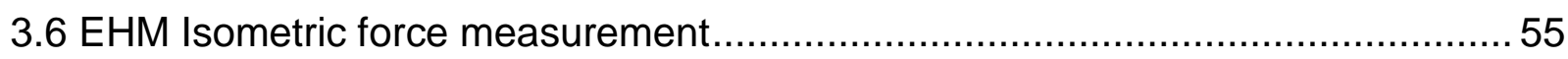

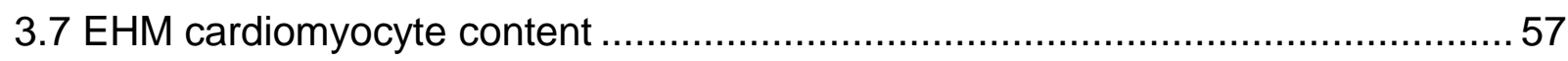

3.8 EHM post transplantation gene expression.............................................. 59

3.9 Superovulation and oocyte retrieval of Rhesus macaque oocytes ....................61

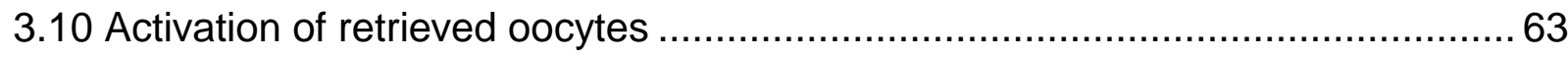




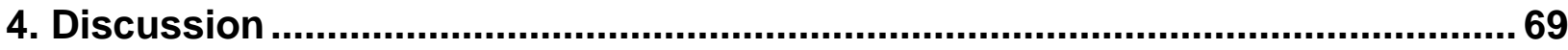

4.1 RhiPS cells can differentiate into spontaneously beating cardiomyocytes ...........70

4.2 EHM can be constructed from RhiPS cell-derived cardiomyocytes .................... 72

4.3 Rhesus macaque EHM appear less mature than human EHM ........................ 73

4.4 iPS reprogramming by integrating vectors increases the likelihood of oncogene

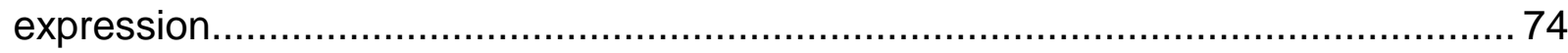

4.5 Encapsulation enhanced directed differentiation in Lenti-iPS cells .................... 75

4.6 RhpSC can be derived from unfertilized oocytes after superovulation ................. 77

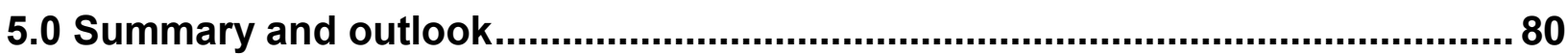

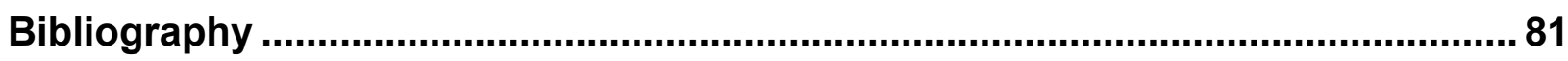

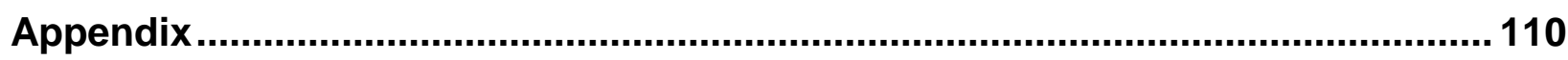




\section{Acknowledgements}

I would like to thank all the people who have accompanied me on this journey. First and foremost, I would like to express my appreciation to my supervisor Prof. Dr. Wolfram-Hubertus Zimmermann for allowing me the opportunity to take on this project and the freedom to be creative and make it work. I would also like to thank both my thesis committee members Prof. Dr. Rüdiger Behr and Prof. Dr. Lutz Walter for their support and assistance throughout this project.

My sincerest gratitude and appreciation goes to Dr. Catherine Vandevoort and Dana Daggett at the UC Davis California National Primate Research Center, who taught me vital knowledge about working with Rhesus macaques. A special thank you goes to all my colleagues at the Institute of Pharmacology who have helped me over the years and put up with my randomness. I would especially like to thank Dr. Malte Tiburcy and Dr. Norman Liaw for answering my never-ending questions. Andreas Schraut and Dr. med. Buntaro Fujita, for their assistance with the cardiomyocytes and EHMs. Dr. vet. Med. Charis Drummer and Sophie Mißbach, from the DPZ, for their assistance with retrieving oocytes and performing the Rhesus macaque surgeries. I would like to thank Dr. Tina Seitz for our afternoon tea breaks and the conversations that made the days that much more bearable. I cannot even begin to give enough thanks and appreciation to Frau Creydt, for her help and assistance since the first day I walked into the department so many years ago.

I would like to say a special thank you to my very caring and supportive wife Katja, for standing beside me through the ups and downs with encouragement, kindness and support throughout the duration of my PhD studies. To my son Til, who gave me strength when it felt like I could go no further and put my life into a whole new perspective. Finally, I would like to express my heart-felt gratitude to my family who I dedicate this dissertation to. My parents, my brother and my extended family, which have all been a constant source of love, inspiration, and strength throughout all these years. None of this would have been possible without the love, understanding and support of my family. 
This work is dedicated to my father who passed away during my PhD candidature.

"Problems are not stop signs; they are guidelines." - Robert Schuller 


\section{Abstract}

Myocardial infarction is the leading cause of death globally. Remuscularization of the heart with stem cell based treatments is one potential approach to heart repair which is presently being tested. Proof-of-concept studies, mostly in rodent models, have shown promising results. Nevertheless, to be therapeutically relevant it is essential to test evolving therapeutic strategies in large animal models with high predictive value as to clinical outcome. Unfortunately, a lack of pluripotent stem cell models available in most animal species used for late stage preclinical testing creates a major challenge. Non-human primate models, and here in particular macaque models, appear to be an exception with the documentation of successful derivation of stable pluripotent stem cell models by several groups. In this dissertation the following hypotheses were tested: (1) induced pluripotent stem (iPS) cells from Rhesus macaque (Macaca mulatta) can be used to derive cardiomyocytes, (2) Rhesus macaque iPS-derived cardiomyocytes can be used to construct engineered heart muscle (EHM) with contractile properties similar to observations in human EHM, (3) parthenogenetic pluripotent stem cells can be derived from Rhesus macaque unfertilized oocytes as an alternative source of pluripotent stem cells with distinct advantages regarding immunological matching. Two available Rhesus iPS cell lines, either generated by lentiviral or Sendai viral transduction of reprogramming factors, were subjected to directed differentiation using a similar protocol as recently established for human pluripotent stem cells. High cardiomyocyte yield and purity could be achieved. Cardiomyocytes differentiated from both iPS cell lines could be used to generate EHM with similar contractile properties. Evidence for successful induction of parthenogenesis was obtained. Collectively, this dissertation provides the methodological groundwork for the implementation of Rhesus macaque pluripotent stem cell derived EHMs for pivotal late stage preclinical studies of tissue engineered heart failure repair. 


\section{List of Figures}

Figure 1: Heart failure caused by myocardial infarction.................................... 3

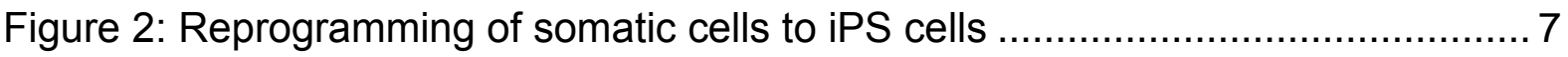

Figure 3: Parthenogenic activation of unfertilized MII oocytes ............................. 9

Figure 4: Possible chromatid arrangements in an oocyte................................. 10

Figure 5: Directed differentiation of cardiomyocytes for EHM generation................ 12

Figure 6: Polysaccharide residues of alginate ........................................... 13

Figure 7: Evolutionary distance of mammalian test models .............................. 15

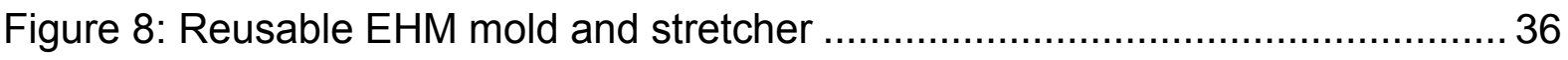

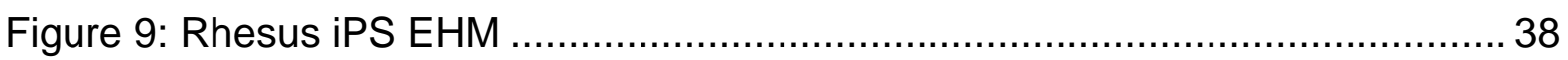

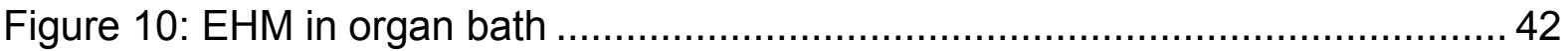

Figure 11: Gating strategy for $\alpha$-actinin positive cardiomyocytes. ........................ 43

Figure 12: Encapsulation of Lenti-iPS cells: ................................................... 47

Figure 13: Increase in cell number following encapsulation. ............................. 48

Figure 14: Cardiomyocyte purity following differentiation in alginate beads. ........... 49

Figure 15: Cardiomyocyte purity following differentiation of Sendai iPS cells in

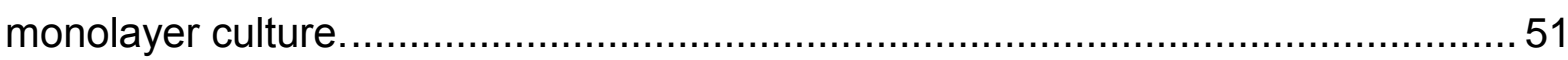

Figure 16: Fluorescence image of RhiPS derived cardiomyocytes ......................5 52

Figure 17: Teratoma assays confirmed pluripotency in Sendai RhiPS cells............5 54

Figure 18: Calcium concentration response in the two tested iPS cell-derived EHM.

Figure 19: Positive inotropic responses to isoprenaline in Rhesus EHM.................56

Figure 20: Negative force-frequency response in Rhesus EHM...........................57

Figure 21: Cardiomyocyte content of Rhesus EHM. .................................... 58

Figure 22: Whole mount staining of RhEHM. ............................................... 59

Figure 23: Ultrasound examination of hormone stimulated Rhesus ovaries............61 61

Figure 24: Excised ovaries from super-ovulated Rhesus macaques...................... 62

Figure 25: Oocytes collected from excised ovaries ....................................... 63

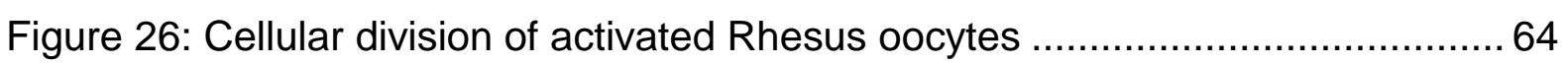

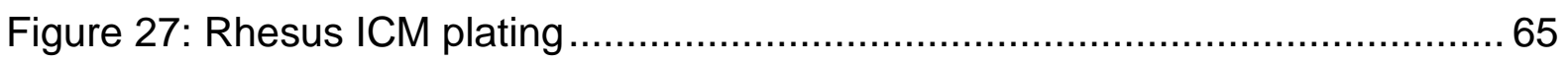

Figure 28: Summary of all Rhesus macaque oocyte activations.........................6 68 


\section{List of Tables}

Table 1: Heart transplants in 2016 in the Eurotransplant zone.............................. 5

Table 2: Comparative heart anatomy and physiological data between human and common heart disease animal models ......................................................... 16

Table 3: Female Rhesus macaques used for superovulation and oocyte harvest. .. 18

Table 4: TALP-HEPES medium for follicle aspiration...................................... 20

Table 5: HECM-9 medium for oocyte activation and culture. ............................. 26

Table 6: Amino acid/Pantothenate solution for oocyte activation and culture..........27

Table 7A: Oligonucleotide sequences for Rhesus MHC class I PCR amplification .. 30

Table 7B: Amplification program for MHC Class I ........................................ 31

Table 8A: Oligonucleotide sequences for Rhesus MHC class II PCR amplification . 34

Table 8B: Amplification program for MHC Class II ........................................ 34

Table 10: Tyrode's solutions for isometric force measurements. .......................... 41

Table 11: Rhesus macaque MHC Class I (Mamu) antigen screening ......................53

Table 12: Comparative RNA expression of pluripotency and cardiomyocyte marker genes in Lenti-EHM explants and Sendai-cardiomyocytes. ...............................6 60

Table 13: Oocyte activations of Rhesus macaques from ovulation cycle 1 .............65

Table 14: Oocyte activations of Rhesus macaques from ovulation cycle 2 .............66

Table 15: Oocyte activations of Rhesus macaques from ovulation cycle 3 .............67

Table 16: Oocyte activation of Rhesus \#2379 ................................................... 67 


\section{Abbreviations}

Asc

ANOVA

BMP4

BSA

C

CHIR

$\mathrm{CO}_{2}$

CVD

Cx43

DAPI

DMEM

DMSO

Dpn

$\mathrm{EC}_{50}$

ECM

EDTA

EHM

ESC

$\mathrm{EtOH}$

FBS

FGF-2

FITC-A

FOC

FSC-A

g

$\mathrm{H}_{2} \mathrm{O}$

hCG

HECM-9

HEPES

hES

hFF

hFSH
Ascorbic acid

Analysis of variance

Bone morphogenetic factor 4

Bovine serum albumin

Celsius/Centigrade

Wnt signaling activator CHIR99021

Carbon dioxide

Cardiovascular disease

Connexin 43 (aka GJA1)

4', 6-diamidino-2-phenylindole

Dulbecco's modified Eagle's medium

Dimethyl sulfoxide

Days postnatal

Half maximum effective concentration

Extracellular matrix

Ethylenediaminetetraacetic acid

Engineered heart muscle

Embryonic stem cell

Ethanol

Fetal bovine serum

Basic fibroblast growth factor

Fluorescein isothiocyanate Area

Force of contraction

Forward scatter area

Gravitational force

Water

Recombinant human chorionic gonadotropin

Hamster embryo culture medium 9

4-(2-hydroxyethyl)-1-piperazineethanesulfonic acid

Human embryonic stem cell

Human foreskin fibroblasts

Recombinant human follicle stimulating hormone 


\begin{tabular}{|c|c|}
\hline $\lg G$ & Immunoglobulin G \\
\hline IM & Intramuscularly \\
\hline IMDM & Iscove's modified Dulbecco's medium \\
\hline iPS & Induced pluripotent stem cell \\
\hline IU & International units \\
\hline IVF & In vitro fertilization \\
\hline IVM & In vitro maturation \\
\hline IWP4 & Inhibitor of Wnt production 4 \\
\hline $\mathrm{KO}$ & Knockout \\
\hline $\mathrm{L}$ & Liter \\
\hline Lenti & Lentiviral transduced RhIPS line C1 \\
\hline LIF & Leukemia inhibitory factor \\
\hline mESC & Mouse embryonic stem cell \\
\hline a-MHC & Myosin heavy chain, alpha isoform (aka MYH6) \\
\hline$\beta-\mathrm{MHC}$ & Myosin heavy chain, beta isoform (aka MYH7) \\
\hline MII & Meiosis II \\
\hline $\mathrm{ml}$ & Milliliter \\
\hline $\mathrm{mN}$ & Millinewton \\
\hline MYC & Transcriptional gene encoding for c-MYC \\
\hline $\mathrm{NaCl}$ & Sodium chloride \\
\hline $\mathrm{NaOH}$ & Sodium hydroxide \\
\hline NEAA & Non-essential amino acids \\
\hline NHP & Non-human primate \\
\hline PBS & Phosphate buffered saline \\
\hline POU5F1 & Transcriptional gene encoding for OCT4 \\
\hline PP & Polypropylene \\
\hline $\mathrm{P} / \mathrm{S}$ & Penicillin/Streptomycin \\
\hline pSC & Parthenogenetic stem cell \\
\hline $\mathrm{Rh}$ & Rhesus macaque (Macaca mulatta) \\
\hline RhGFB & Rhesus gingival fibroblasts \\
\hline RhiPS & Rhesus macaque induced pluripotent stem cell \\
\hline RhpSC & Rhesus parthenogenetic stem cell \\
\hline RI & ROCK inhibitor Y-27632 \\
\hline RPMI & Roswell Park Memorial Institute \\
\hline
\end{tabular}


RT

SEM

SFBM

SFMM

SSC-A

TALP

TGF- $\beta$

U

V
Room temperature

Standard error of the mean

Serum free basal medium

Serum free maturation medium

Side scatter area

Tyrode's albumin lactate pyruvate

Transforming growth factor beta

Unit

Volts 


\section{Introduction}

Cardiovascular diseases (CVD) cause $31 \%$ of all deaths and thus are considered the number one cause of death globally (WHO 2016). The associated long term consequences of CVD place an increasing health and economic burden on society. As the global population continues to increase and live longer than any previous generation, the demands on the scientific and medical communities to create more specialized and personalized medicine is greater than ever before. Stem cells can be derived from individual patients and thus appear well suited as personalized therapeutics, including cell-based therapeutics for heart repair. Remuscularization of the heart is one potential approach to heart repair which is presently tested either by the implantation of pluripotent stem cell derived cardiomyocytes (Chong et al. 2014, Klug et al. 1996, Shiba et al. 2012, Shiba et al. 2016) or engineered heart muscle constructs (Zimmermann et al. 2006, Didie et al. 2013, Riegler et al. 2015, Weinberger et al. 2016). After proof-of-concept in mostly rodent models, it is absolutely essential to test the evolving therapeutic strategies in large animal models with high predictive value as to clinical outcome. Large animal models with widespread use in late preclinical studies include dogs, sheep, pig and non-human primate (NHP). However, the lack of pluripotent stem cell models in most of these species constitutes a major challenge. An exception is the NHP model. Several groups have demonstrated that robust pluripotent stem cell models can be derived from various NHPs, including macaque species - Macaca mulatta (Chan et al. 2010, Liu et al. 2008), Macaca fascicularis (Deleidi et al. 2011, Shiba et al. 2016), Macaca nemestrina (Kiem et al. 2004, Sourisseau et al. 2013) - as well as the common marmoset, Callithrix jacchus (Tomioka et al. 2010, Wu et al. 2010) - and the olive baboon - Papio anubis (Navara et al. 2013). These models utilize embryonic stem cells (ESC; Debowski et al. 2016, Thomson et al. 1995), induced pluripotent stem cells (iPSCs; Debowski et al. 2015, Liu et al. 2008, Zhong et al. 2011), and parthenogenetic stem cells (pSCs; Mitalipov et al. 2001, Vrana et al. 2003). Moreover, the close phylogenetic distance between macaque and human was used as a rationale for studies testing the electromechanical integration of human embryonic stem cell-derived cardiomyocytes in macaque models (Chong et al. 2014). Immunologically more relevant allograft studies have recently been performed in Rhesus macaque (Shiba et al. 2016) with similar results 
as in the aforementioned xenograft study. The importance of NHP models is further exemplified by earlier studies in guinea pig with opposite results as to the side effects elicited by the cardiomyocyte grafts: namely, anti-arrhythmic effects of human cardiomyocyte grafts in the guinea pig model (Shiba et al. 2012) and pro-arrhythmic effects in the macaque model (Shiba et al. 2016) .

Accurate and reproducible animal models of human diseases are invaluable in not only their utilization for pre-clinical treatment evaluations, but also in their ability to provide a deeper and better understanding of disease mechanisms. Rats and mice represent the most common preclinical animal models, mainly because of relatively low costs, easy breeding with short lifecycles (1-2 years), and high reproduction rates as well as the possibility for genetic manipulations in genetically defined backgrounds. However, differences in physiology, and in particular cardiovascular physiology, limit their predictive value for clinical outcome. Animals such as sheep and pigs are more closely related in physiology to humans and have been previously used in myocardial infarction and stem cell studies (Dayan et al. 2016, McCall et al. 2012). However, with regards to their use in stem cell studies, their limitation is in the high level of difficulty present in generating species-specific stem cells (Harding et al. 2013).

\subsection{The human heart}

The heart is a complex, multicellular, four chambered pump designed to propel blood through more than 60,000 miles of vasculature (Rajendran et al. 2013) in the adult human. Starting at day 20 of embryogenesis, the human heart begins to beat (Moorman et al. 2003). From this point on, the heart is continuously transporting blood throughout the body (Moorman et al. 2003), making it the longest continuously functioning organ in the body. In a normal human heart, cardiomyocytes comprise $75 \%$ of the total volume but only account for $30-40 \%$ of the total cell number (Vliegen et al. 1991). The non-myocyte fraction consists of fibroblasts, smooth muscle cells, endothelial cells (Camelliti et al. 2005), and transient immune response cells (lymphocytes, macrophages, and mast cells). These cells must work in precise harmony to maintain proper function and homeostasis of the heart. The specific morphological transition and intramyocardial arrangement of cardiomyocytes from an elongated, ovoidal embryonic phenotype to a rod-shaped adult phenotype enables the cardio- 
myocytes to maintain electrically and mechanically networked connectivity and anisotropy ensuring the highly-synchronized contractility of the adult heart. This highly specialized nature of adult cardiomyocytes comes at the cost of a having very limited, if any, regenerative capacity (Laflamme and Murry 2011, Lundy et al. 2013).

\subsection{Heart failure}

The chance of developing heart failure has been calculated at one in five over the course of a human lifetime (Bui et al. 2011). Myocardial infarction, affecting typically the left ventricle, is one of the main reasons for heart failure development. The left ventricle of young adults (17-30) consists of approximately $6 \times 10^{9} \pm 1.8 \times 10^{9}$ cardiomyocytes and decreases up to $33 \%$ to $4 \times 10^{9} \pm 1.3 \times 10^{9}$ between ages $65-90$ (Olivetti et al. 1991). Approximately 1 billion cardiomyocytes are usually lost in the left ventricle of the human heart following a myocardial infarction (Gepstein 2002, Laflamme and Murry 2005). In response to this loss of myocardium, a remodeling cascade, mediated by fibroblasts and myofibroblasts, is initiated to prevent ventricular wall rupture (Shinde and Frangogiannis 2014, van den Borne et al. 2010). This remodeling cascade results in both functional and morphological changes to the myocardium in the form of fibrosis. Over time, the chronic stresses inherent from maladaptive remodeling lead to more severe CVD states including; ventricular dilation, cardiac fibrosis, cardiomyocyte hypertrophy, and chronic inflammation (Figure 1).

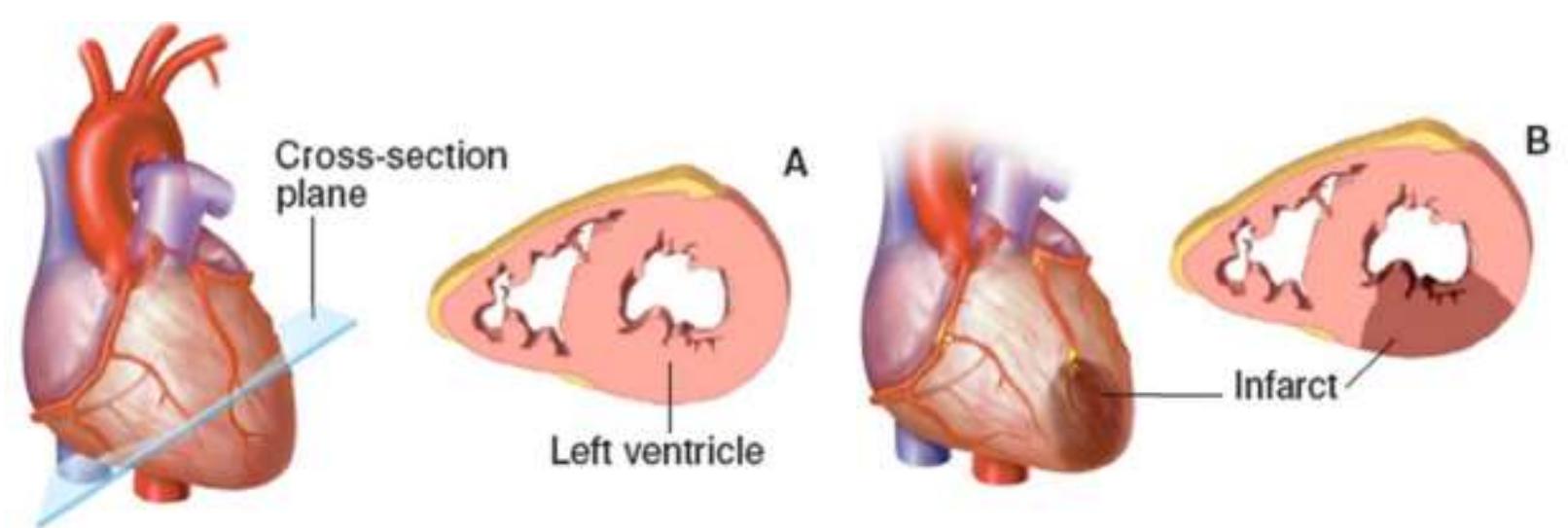

\section{Figure 1: Heart failure caused by myocardial infarction}

Myocardial infarction causes the death of approximately 1 billion cardiomyocytes, usually in the left ventricle of the heart. Due to the limited capacity of the heart to re- 
place the cardiomyocytes, tissue scarring occurs and results in decreased left ventricular output. (image modified from Goldthwaite 2006)

\subsection{Heart failure treatments}

Current treatment modalities following myocardial infarction consist of surgical repair procedures, pharmaceutical drug interventions, mechanical assistance device implantations, and organ transplantations. Despite advances in these treatments, patients suffering from heart failure still face substantial morbidity and mortality within the 5 years following a cardiac incident (Bui et al. 2011). Full organ transplantations are currently the only course of action for patients with chronically scarred myocardium and end-stage heart failure. In 2016, 702 people were on a waiting list for a heart only transplant, with nearly half already having waited 24 months or more (Table 1A). This relatively low number of patients on the heart transplant waiting list, in light of the huge number of patients affected by heart failure, is a result of very stringent selection criteria, e.g., patients with an age above 65 are typically not considered. Finally, the total numbers of patients with end stage heart failure in need of heart transplantation in Germany are estimated to be approximately 8,000. In 2016, only 297 heart transplants (287 heart only, 10 heart + other organ) were performed in Germany (Table 1B). In light of changing patient demographics, this number and thus the need for advanced heart failure therapeutics will further increase.

As an alternative to full organ replacement, stem cell based treatments have gained intense interest as an option for physical replacement of damaged tissues in patients with end stage heart failure (Agnetti et al. 2015, Nicolini et al. 2015). Stem cell based treatment options consist primarily of direct injection (reviewed in Terrovitis et al. 2010) or application of cell patches (reviewed in Ye et al. 2013). Both treatments are being investigated with either non-cardiac cells (Farahmand et al. 2008, Mazo et al. 2010) or stem cell derived cardiomyocytes (Chong et al. 2014, Riegler et al. 2015, Weinberger et al. 2016) 
Active heart-only waiting list (at year end) in 2016, by country, by characteristics

\begin{tabular}{|c|c|c|c|c|c|c|c|c|}
\hline Monthis waiting (on WL) & A & B & D & H & HR & NL. & SLO & Total \\
\hline 0.5 & 21 & 28 & 136 & 18 & 18 & 20 & 16 & 257 \\
\hline 6-11 & 12 & 34 & 115 & 10 & 11 & 22 & 12 & 216 \\
\hline $12-23$ & 8 & 42 & 138 & 5 & 3 & 33 & 15 & 244 \\
\hline $24+$ & 10 & 9 & 313 & 15 & 2 & 24 & 7 & 380 \\
\hline Total & 51 & 113 & 702 & 48 & 34 & 99 & 50 & 1097 \\
\hline Age: & A & B & D & H & HR & NL & SLO & Total \\
\hline $0-15$ & 2 & & 34 & & 1 & 3 & & 40 \\
\hline $16-55$ & 25 & 70 & 356 & 30 & 16 & 60 & 26 & 583 \\
\hline $56-64$ & 16 & 32 & 251 & 17 & 14 & 29 & 19 & 378 \\
\hline $65+$ & 8 & 11 & 61 & 1 & 3 & 7 & 5 & 96 \\
\hline Total & 51 & 113 & 702 & 48 & 34 & 99 & 50 & 1097 \\
\hline Uroency & A & B & D & H & HR & NL & SLO & Total \\
\hline Elective & 48 & 111 & 614 & 48 & 28 & 96 & 42 & 987 \\
\hline High Urgency & 3 & 2 & 88 & & 6 & 3 & 8 & 110 \\
\hline Total & 51 & 113 & 702 & 48 & 34 & 99 & 50 & 1097 \\
\hline
\end{tabular}

Heart transplants in 2016, by country, by donor type, by organ combination

\begin{tabular}{|r|r|r|r|r|r|r|r|r|r|}
\hline Deceased donor transplants & \multicolumn{1}{|c|}{ A } & \multicolumn{1}{|c|}{ B } & \multicolumn{1}{c|}{ D } & H & HR & NL & SLO & Non-ET & Total \\
\hline heart & 56 & 68 & 287 & 58 & 35 & 35 & 30 & 4 & 573 \\
\hline heart + lungs & & 2 & 7 & & & & & & 9 \\
\hline heart+ liver & & & 1 & & & & 1 & & 2 \\
\hline heart+ kidney & 1 & & 2 & & & & & & 3 \\
\hline Total & 57 & 70 & 297 & 58 & 35 & 35 & 31 & 4 & 587 \\
\hline
\end{tabular}

Table 1: Heart transplants in 2016 in the Eurotransplant zone

A) In 2016, over 700 people were actively waiting for a heart transplant in Germany, with almost $45 \%$ of patients waiting for a suitable donor for 24 months or more. B) Due to a lack of suitable heart transplants only 297 heart transplants were performed in Germany during 2016. ( $A=$ Austria, $B=$ Belgium, $D=$ Germany, $H=$ Hungary, $H R=$ Croatia, $\mathrm{NL}=$ Netherlands, $\mathrm{SLO}=$ Slovenia. Images modified from http://statistics.eurotransplant.org/, accessed 28 February 2017.) 


\subsection{Stem cells}

Stem cells are defined as cells that can self-renew and proliferate in an undifferentiated state indefinitely. These cells give rise to every cell type in the body. Stem cells are classified into four categories dependent on their differentiation potential: totipotent, pluripotent, multipotent, or unipotent. Blastomeres produced by the first zygotic divisions can differentiate into all cell types and thus are considered totipotent. Pluripotent stem cells can differentiate into almost all cell types and include blastocoel derived embryonic stem cells (ESC), induced pluripotent stem cells (iPS), and parthenogenetic stem cells ( $\mathrm{pSC}$ ). Multipotent and unipotent stem cells are of adult origin and give rise to cells within their related family - such as adult hematopoietic stem cells - or cells that possess the ability to self-renew, but are only capable of producing cells of their own type, such as muscle stem cells.

\subsubsection{Embryonic stem cells}

Derived from the inner cell mass of blastocyst stage preimplantation embryos, ESCs were first generated from mice by Martin Evans at Cardiff University (Evans and Kaufman 1981). Over the course of the following decades, ESCs were generated from other animals including hamsters (Doetschman et al. 1988), sheep (Notarianni et al. 1991), rabbits (Graves and Moreadith 1993), non-human primates (Thomson et al. 1995), humans (Thomson et al. 1998), canines (Hatoya et al. 2006), and rats (Li et al. 2008). ESC-like cell lines have also been generated from cattle (Saito et al. 1992) and pigs (Hou et al. 2016). ESCs possess the ability to proliferate in an undifferentiated state indefinitely, giving rise to every cell type in the body. Of note, although a vast amount of ESCs from various species has been reported, there is a huge discrepancy as to the actual acceptance as bona fide pluripotent stem cells in the field. Especially, stable long term maintenance of a pluripotent state and susceptibility to directed differentiation has been limited to mouse, macaque and human ESCs. The discovery of human ESCs has however brought with it legal and ethical issues primarily associated with the destruction of the blastocyst stage embryos used to isolate the inner cell mass, from which ESCs are derived (Hyun 2010).

\subsubsection{Induced pluripotent stem cell}

In 2006, it was reported that mouse fibroblasts could be reprogrammed back to a pluripotent state using four reprogramming factors delivered via retroviruses 
(Takahashi and Yamanaka 2006). A year later, human iPS cells were generated making it possible to transform a patient's own somatic cells back into stem cells and then differentiate those cells into practically any cell required for a therapeutic treatment (Takahashi et al. 2007). Much like their predecessors before them, iPS cells have also been generated from a variety of species, including Rhesus macaque (Liu et al. 2008), rats (Liao et al. 2009), rabbits (Honda et al. 2010), and canines (Koh and Piedrahita 2015). With iPS cells, it is possible to generate stem cell lines from multiple somatic cells sources without the destruction of blastocyst stage embryos (Egusa et al. 2010).
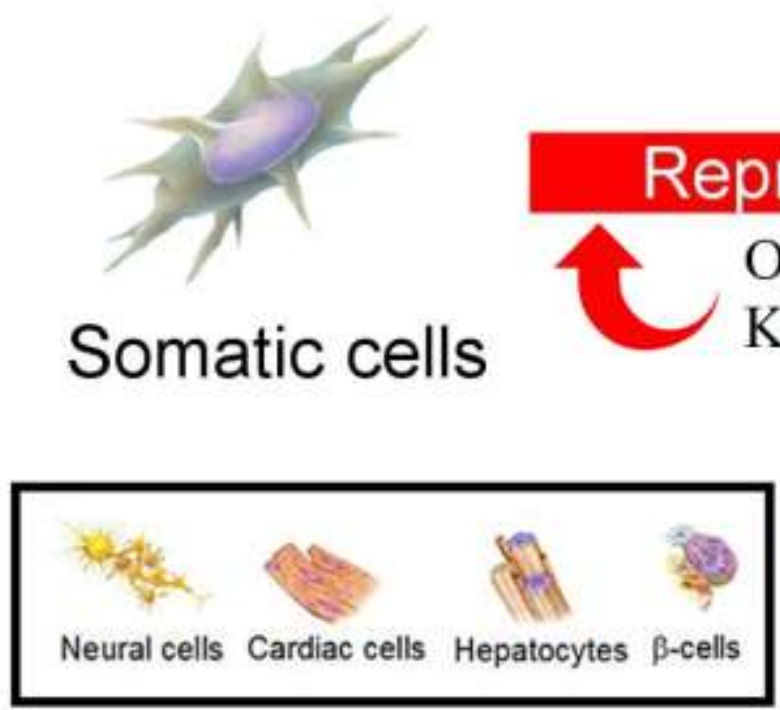

\section{Reprogramming}

Oct-4, Sox2, $\mathrm{Klf} 4$, (c-myc)

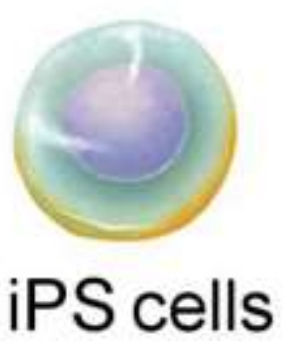

iPS cells

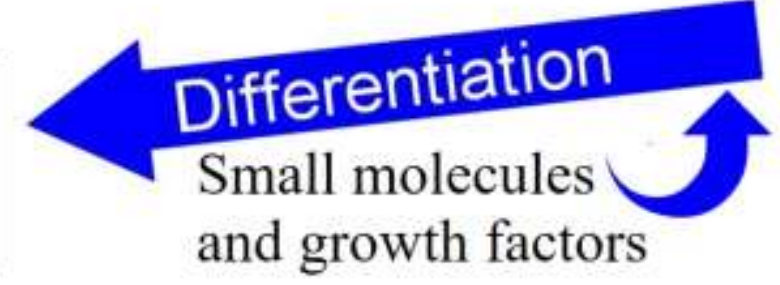

Figure 2: Reprogramming of somatic cells to iPS cells

Generation of iPS cells from somatic cells requires the viral transduction of four transient pluripotency genes: Oct-4, Sox2, KIf4, and c-Myc. Once transduced, iPS cells can be terminally differentiated into any cell in the body.

\subsubsection{Parthenogenetic stem cells}

Similar to ESC, parthenogenetic stem cells (pSC) are generated by isolation of the inner cell mass of a blastocyst (Revazova et al. 2007). The difference is, however, that these are non-embryonic blastocysts and thus the term "parthenogenetic embryonic stem cells" used by some authors is a clear misnomer. To date, parthenote blastocysts have been generated in human (de Fried et al. 2008, Revazova et al. 2007), non-human primates (Mitalipov et al. 2001, Vrana et al. 2003), rabbit (Naturil- 
Alfonso et al. 2015), goat (Kharche et al. 2014), mouse (Cui et al. 2007, Didie et al. 2013), and pig (Marques et al. 2011). Stable pSC lines have so far only been generated from human (Harness et al. 2011, Revazova et al. 2008, Turovets et al. 2011), non-human primate (Dighe et al. 2008, Mitalipov et al. 2001, Vrana et al. 2003, Yang et al. 2013), and mouse (Chen et al. 2009, Didie et al. 2013). To generate an inner cell mass for the derivation of pSCs, metaphase II (MII) oocytes are activated through exposure to exogenous calcium $\left(\mathrm{Ca}^{2+}\right)$, causing an increase of intracellular $\mathrm{Ca}^{2+}$. The exposure of an unfertilized oocyte to $\mathrm{Ca}^{2+}$ mimics the release of phospholipase C-zeta (PLC- $\zeta$ ) - otherwise known as the "sperm factor" - from the sperm head during fertilization. This binds to the inositol 1,4,5-trisphospahte receptors (IP3R) of the endoplasmic reticulum and initiates $\mathrm{Ca}^{2+}$ oscillations in a positive $\mathrm{Ca}^{2+}$ feedback loop, resulting in the resumption of meiosis II (Saunders et al. 2002, Swann and $\mathrm{Yu}$ 2008). PLC- $\zeta$ has been found to be associated with the induction of $\mathrm{Ca}^{2+}$ oscillations of fertilized eggs in chickens (Coward et al. 2005), bovine (Ross et al. 2008), as well as human and non-human primates (Cox et al. 2002, Rogers et al. 2004). Since there is no paternal DNA present in the activated oocyte, the chromosomal zygosity of the resulting pSC is dependent upon the activation protocol used (Revazova et al. 2008).

\subsubsection{Parthenote zygosity}

pSCs can be derived from activated meiosis II oocytes either before or after extrusion of the $2^{\text {nd }}$ polar body, resulting in partly heterozygous or strictly homozygous genomes, respectively (reviewed in Daughtry and Mitalipov 2014). 


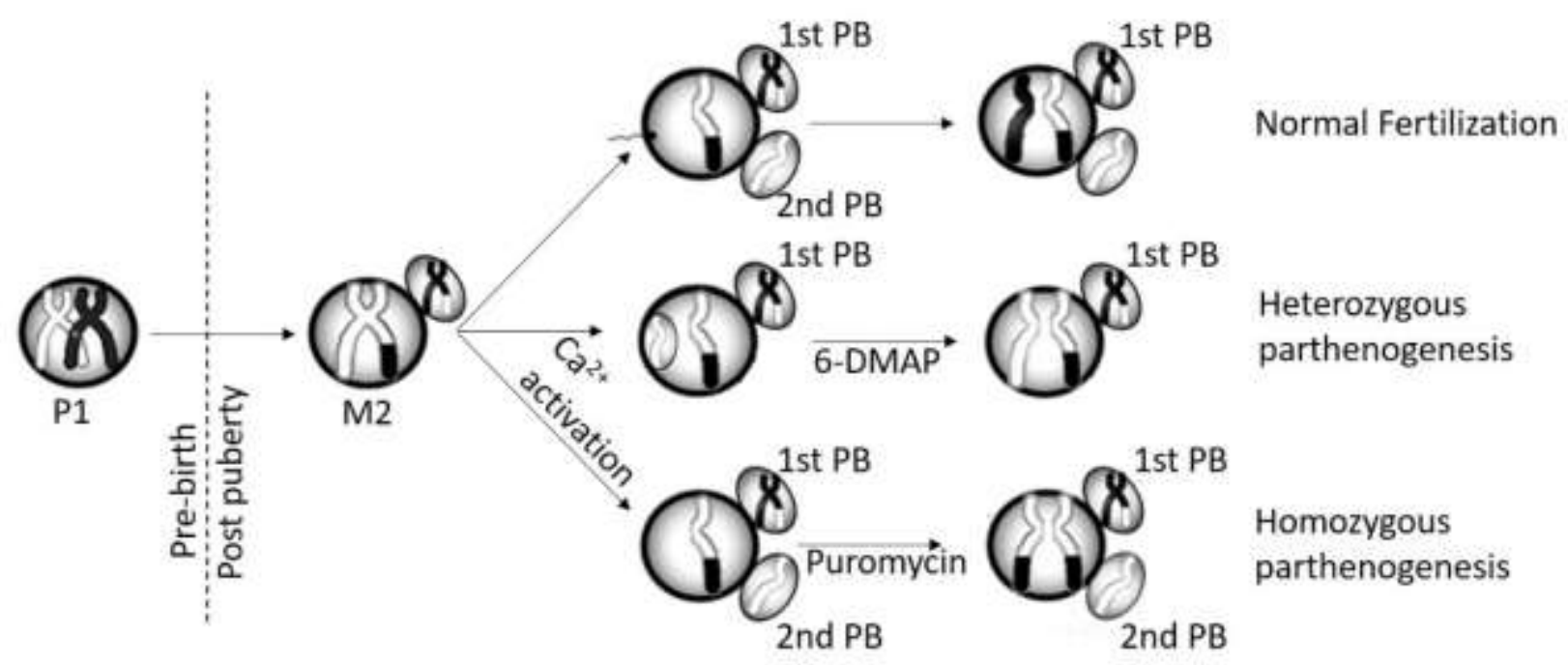

Figure 3: Parthenogenic activation of unfertilized Mll oocytes

During normal fertilization, resumption of meiosis II occurs when a sperm penetrates the MII oocyte, triggering a calcium release. Immediately following this reactivation, the sister chromatids are segregated. One chromatid is packaged into the second polar body and is extruded. The other chromatid is supplemented with the paternal chromatid supplied by the sperm which results in the formation of a diploid zygote. Parthenogenetic activation of an arrested MII oocyte is achieved through exposure to exogenous calcium. Immediately following activation, incubation with 6-DMAP causes the retention of the second polar body within the oocyte. Incubation with puromycin does not inhibit second polar body extrusion, resulting in a transient haploid state. DNA-synthesis typically sets in to support the formation of a homozygous diploid state (Image modified from Daughtry and Mitalipov 2014).

Heterozygosity results from crossing over events during meiosis I with exchange of genome information from one of the two alleles within a pair of matching parental chromosomes (Figure 4). In metaphase II oocytes, derived after blockade of the extrusion of the $2^{\text {nd }}$ polar body, diploid pSCs exhibit a large degree of heterozygosity in genes encoded distant from the centromere; conversely, genomic sequences close the centromere are typically homozygous (Didie et al. 2013, Kim et al. 2007b). 


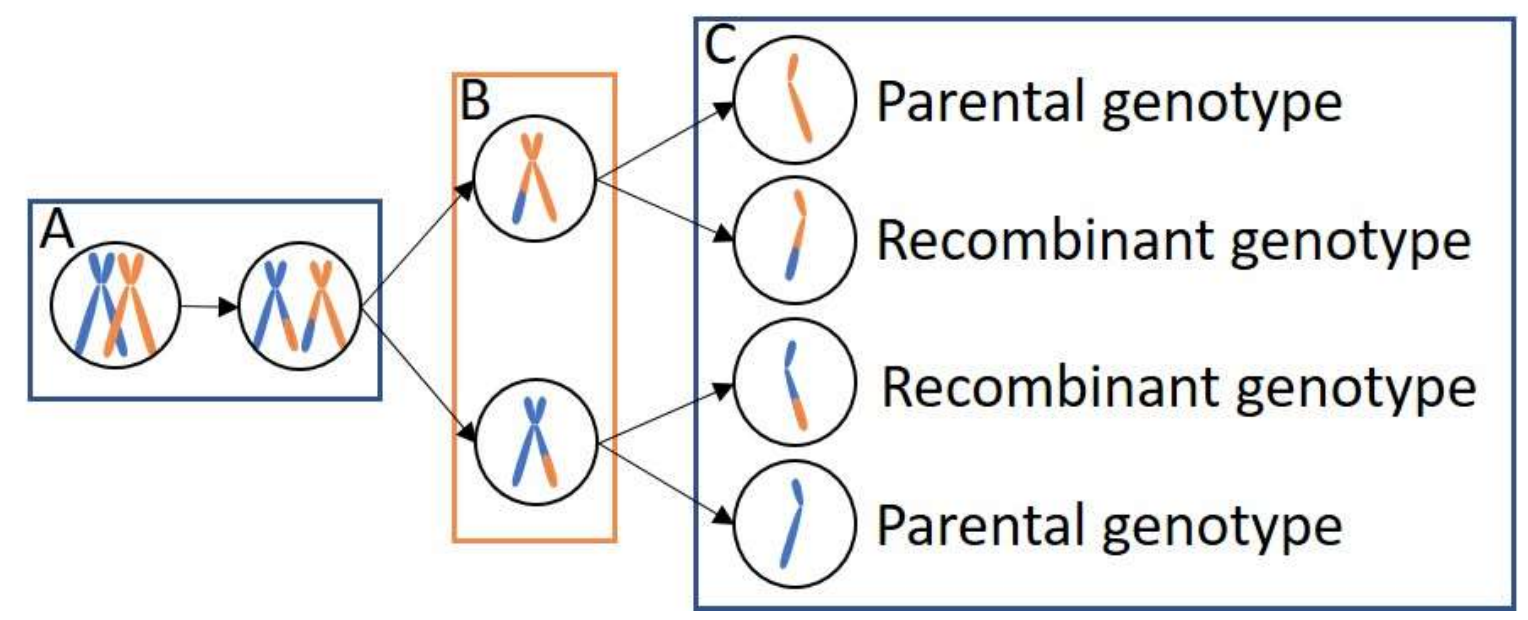

Figure 4: Possible chromatid arrangements in an oocyte

Chromosomes are comprised of two sister chromatids bound together by a centromere. A) Prior to birth, during prophase (PI) of meiosis I in oogenesis, chromosomal crossing occurs when matching regions of two sister chromatids from separate homologous chromosomes break apart and recombine on opposite chromatid strands that are near each other. This chromosomal crossing over results in recombinant chromosomes that are genetically diverse from the parental chromosomes. Following this crossing over event, oogenesis is halted. B) When puberty is reached meiosis I is resumed and the first polar body is formed and extruded. The first polar body contains one full half of the original oocyte's diploid chromosome set. The observance of an extruded first polar body within the zona pellucida of the oocyte signifies the advancement of the oocyte to the metaphase II (MI) stage of meiosis II. At this point, oogenesis is halted until activation of the MIl oocyte either by fertilization or parthenogenetic activation. C) Schematic display of four genotypic possibilities for a haploid oocyte dependent upon on how the chromatids recombine (crossing over) and separate during meiosis $\mathrm{I}$ and II, respectively. Image modified from http://www.mun.ca/biology/desmid/brian/BIOL2060/BIOL2060-20/20_16.jpg

Extrusion of the $2^{\text {nd }}$ polar body is typically achieved by blockade of mitotic spindle activity either with cytochalasin B (Didie et al. 2013, Kim et al. 2007a) or treatment with 6-dimethylaminopurine (6-DMAP; Revazova et al. 2007, Turovets et al. 2011), a potent non-specific protein kinase inhibitor and cyclin-dependent kinase inhibitor, which disrupts proper mitotic spindle formation and thus results in the retention of the 
now separated set of sister chromatids. An alternative method is by the treatment with puromycin, an antibiotic protein synthesis inhibitor, which does not inhibit the extrusion of the $2^{\text {nd }}$ polar body (Sagi et al. 2016a, Sagi et al. 2016b). The resulting haploid pSCs can be maintained for some passages in a haploid state, but typically convert to diploid pSCs with a completely homozygous genome (Figure 3). In both cases, heterozygote and homozygote pSC, major histocompatibility complex (MHC) information, which is essential for the detection of self and non-self antigens, is typically homozygous because it is encoded in close distance to the centromere on the short arm of chromosome 6 in humans (reviewed in Horton et al. 2004), and chromosome 17 in mouse (Didie et al. 2013). The Rhesus macaque MHC homolog, Mamu, is located similarly as the human HLAs on chromosome 6. In contrast to the human chromosome 6 , the Rhesus chromosome 6 is extended by genomic duplications (Huber et al. 2003). Because of the wide-spread encoding of the MHC information on chromosome 6 (telomere $\rightarrow$ centromere: HLA-A/MamuA $\rightarrow$ HLAB/MamuB $\rightarrow$ HLA-DR/MamuDR; (Daza-Vamenta et al. 2004) creating fully homozygous pSC may be advantageous. MHC homozygosity results in reduced variability of MHC protein combinations and thus is considered an advantage for immune matching (Didie et al. 2013, Nakatsuji et al. 2008, Taylor et al. 2005, Taylor et al. 2012).

\subsection{Directed cardiomyocyte differentiation}

After the isolation and culture of human embryonic stem cells (hES) and the demonstration of their pluripotency, including the propensity to give rise to cardiomyocytes in 1998 (Thomson et al. 1998), suspension cultures of hES aggregates were introduced to study cardiomyogenesis in more detail (Kehat et al. 2001). Directed differentiation for increased cardiomyocyte yields were first established in monolayer cultures (Burridge et al. 2007, Burridge et al. 2011, Burridge and Zambidis 2013, Kattman et al. 2011, Laflamme et al. 2007, Lian et al. 2012, Lian et al. 2013, Xu et al. 2011) and further optimized for higher yields in stirring bioreactors (Chen et al. 2015, Kempf et al. 2014, Olmer et al. 2010, Riegler et al. 2015). All more recent protocols use defined factors and small molecules to modulate the Wnt-signal cascade (Figure 5) for optimal results (Hudson and Zimmermann 2011). Metabolic selection via glucose starvation may be used to further enhance cardiomyocyte purity (Sharma et al. 2015, Tohyama et al. 2013). 


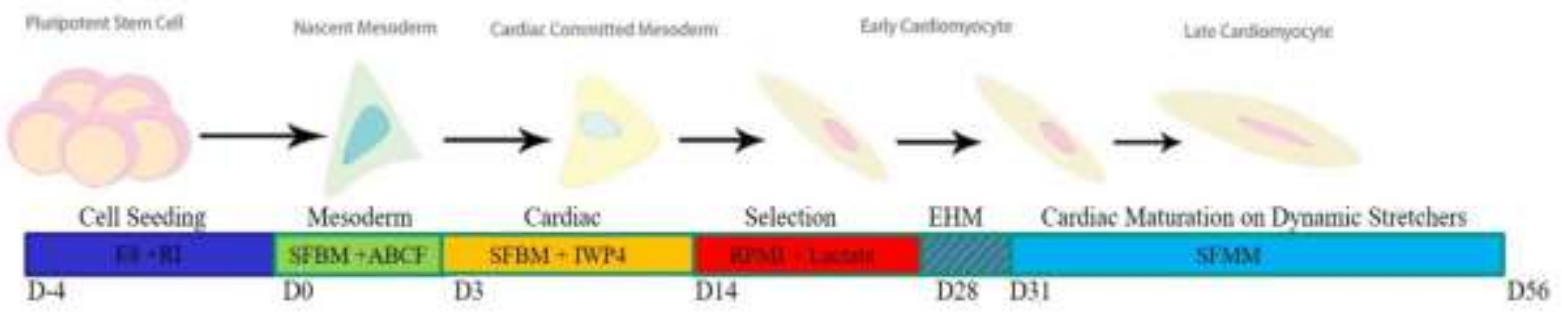

Figure 5: Directed differentiation of cardiomyocytes for EHM generation

Stem cells are seeded in feeder free culture and sequentially treated with small molecules for 14 days, followed by metabolic selection for cardiomyocytes. Following differentiation, cardiomyocytes are combined with fibroblasts in a collagen matrix to form EHMs and cultured on dynamic stretchers to facilitate auxotonic contractions (Tiburcy et al. 2017). A: activin-A, B: BMP4, C: CHIR99021, E8: mTeSR E8 medium, F: FGF-2, IWP4: inhibitor of Wnt production 4, RI: Rock Inhibitor Y27632, RPMI: Rosewell Park Memorial Institute medium, SFBM: Serum Free Basal Medium, SFMM: Serum Free Maturation Medium, d: days).

\subsection{Alginate encapsulation}

The application of bioreactor cultures is essential for enhanced cardiomyocyte yields (Chen et al. 2015, Riegler et al. 2015). To control the cell growth and differentiation in stirred bioreactors, encapsulation has been applied (Jing et al. 2010, Serra et al. 2011). Sodium alginate is an anionic polysaccharide extracted from the cell walls of brown seaweed which can be used for controlled encapsulation of cells (Sidhu et al. 2012, Wilson et al. 2014). It is comprised of (1-4)-linked $\beta$-D-mannuronate(M) and $\alpha$ L-guluronate $(G)$ residues (Figure 6 ) covalently linked as linear monomers of consecutive residues: M-blocks, G-blocks, or MG-Blocks. When alginate is exposed to a solution containing multivalent cations, such as calcium, the sodium ions are replaced, and the polymers become ionically cross linked and form a hydrogel (Figure 6). The encapsulation of stem cells in alginate creates a three-dimensional developmental niche like that provided during embryogenesis (Sidhu et al. 2012, Wilson et al. 2014). Alginate encapsulation has been used in a variety of applications such as: the culture of stem cells (Agarwal et al. 2013, Siti-Ismail et al. 2008), differentiation of stem cells (Dixon et al. 2014, Wilson et al. 2014), as a tissue engineering scaffold (Dahlmann et al. 2013, Rosellini et al. 2009, Ruvinov and Cohen 2016), as a delivery 
system for cell based therapy (Levit et al. 2013, Luca et al. 2014), and therapeutic drug delivery (Giovagnoli et al. 2014).

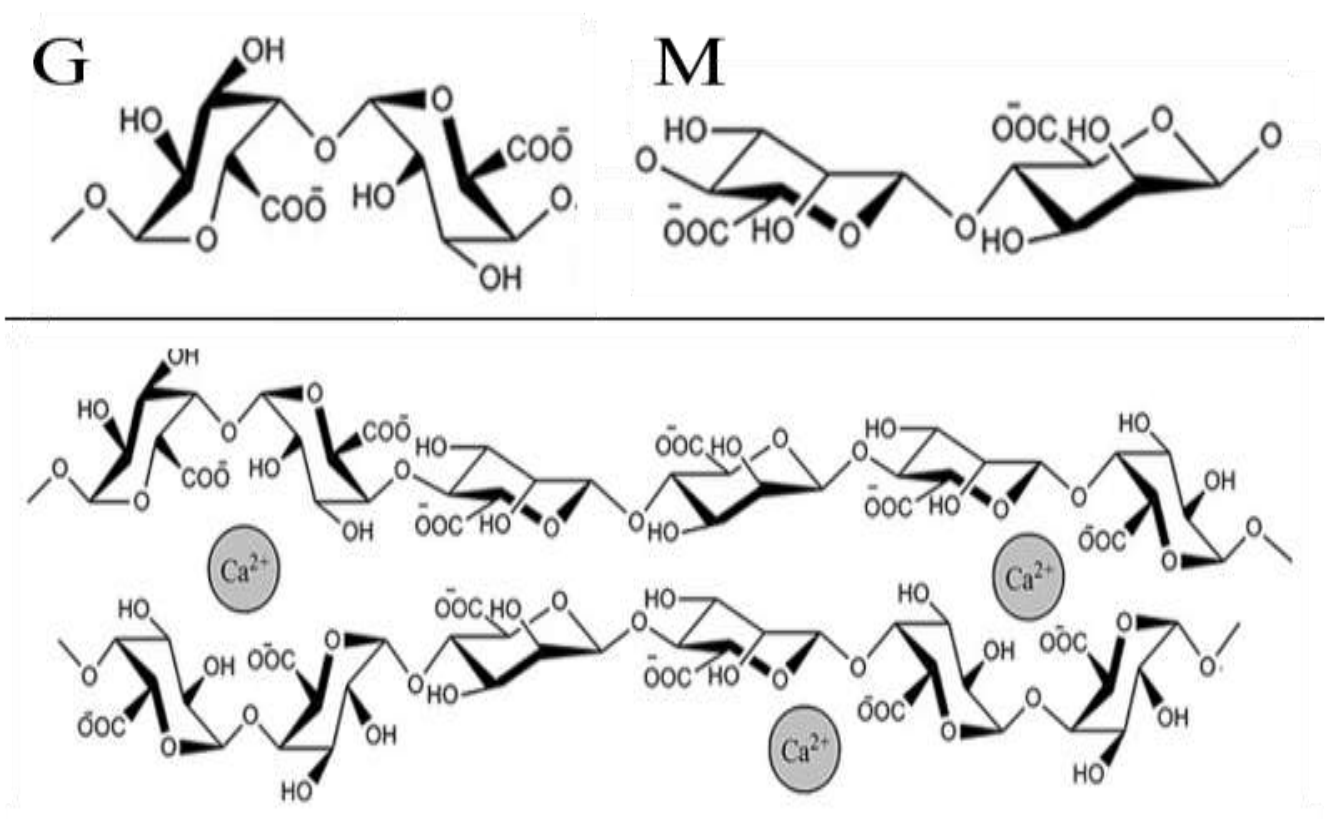

\section{Figure 6: Polysaccharide residues of alginate}

Alginate is a polysaccharide extracted from cell walls of brown seaweed comprised of $\alpha$-L-guluronate $(G)$ and (1-4)-linked $\beta$-D-mannuronate $(M)$ monomer residues (top). When exposed to a solution containing divalent ions, the sodium ions are replaced and the monomers become crosslinked as a hydrogel (bottom; images modified from Paredes Juarez et al. 2014).

\subsection{Engineering of heart muscle}

The in vitro generation of heart tissue was developed as a three dimensional surrogate cardiac tissue for the investigation of various important themes in cardiac research: assessment of pharmaceutical interventions, biophysical development of cardiac organogenesis in vitro, and the feasibility of a engineered heart construct for the repair of damaged myocardium post myocardial infarction (Eschenhagen et al. 1997, Naito et al. 2006, Zimmermann et al. 2006, Zimmermann et al. 2000, Zimmermann et al. 2002, Zimmermann and Eschenhagen 2003). At first, engineered heart tissue was constructed using embryonic chicken cardiomyocytes in a collagen matrix (Eschenhagen et al. 1997) and neonatal rat cardiomyocytes in a colla- 
gen/matrigel ${ }^{\mathrm{TM}}$ matrix (Zimmermann et al. 2000). These constructs were used to directly measure isometric contractile forces in response to increases in mechanical strain, electrical stimulation, and pharmacological stimuli. Further optimization of the tissue engineering protocols resulted in the successful generation of engineered heart muscle (EHM) from human ESC (Soong et al. 2012, Tiburcy and Zimmermann 2014), mouse pSC (Didie et al. 2013), and human iPS cells (Streckfuss-Bomeke et al. 2013). In the most recent protocol, EHM are constructed under serum-free conditions from defined mixtures of cardiomyocytes derived from ESC or iPS cells and fibroblasts in a collagen matrix (Tiburcy et al. 2017) .

EHM culture resulted in a so far unsurpassed degree of maturation in ESC- and iPS cell-derived cardiomyocytes (Tiburcy et al. 2017). This includes the presence of Frank-Starling and Bowditch responses as well as responsiveness to pharmacological interventions similar to what can be observed in bone fide myocardium. An unbiased RNAseq experiment confirmed the advanced degree of maturation, but also demonstrates that maturation remains low compared to adult myocardium. Despite this caveat, application in heart repair (Qin et al. 2016, Riegler et al. 2015) and disease modelling (Tiburcy et al. 2017) has been attempted successfully.

\subsection{Animal models}

Multiple animal models have been utilized in the study of heart failure. Canines were originally used in the 1970's to study cell death due to myocardial ischemia (Reimer et al. 1977, Reimer and Jennings 1979) and later for the studies of reperfusion (Jugdutt and Menon 2004, Przyklenk et al. 1986). Major drawbacks of the canine as a surrogate human heart failure model include its myocardial collateral circulation (White et al. 1986) and the inability to easily and accurately produce a myocardial infarction phenotype (Sabbah et al. 1991). Pigs and sheep have become reasonable alternatives to canines for myocardial studies due to their lack of myocardial collateral vasculature and similar gross cardiac anatomy to humans (Weaver et al. 1986), and the ability to create predictable and reproducible myocardial infarctions (Gorman et al. 1998, Jackson et al. 2002, Markovitz et al. 1989). Pigs and sheep have been used as human surrogates for testing of non-pharmaceutical therapies (Blom et al. 2005, Sabbah et al. 2003), pharmacological therapies (Lu et al. 2007), heart valve 
replacement (Flanagan et al. 2009, Honge et al. 2010), and cell injection therapies (Zeng et al. 2007, Zhang et al. 2007).

Evolutionarily, non-human primates are the most closely related large animals to humans used as surrogates in scientific research (reviewed in Phillips et al. 2014). Humans belong to the family Hominidae or "Great apes" along with chimpanzees, gorillas, and orangutans. NHPs from the great apes have not been used in research in Europe since 1999 (Prescott 2010). Old World and New World monkeys are the most predominately used NHPs in scientific research respectively (Carlsson et al. 2004).

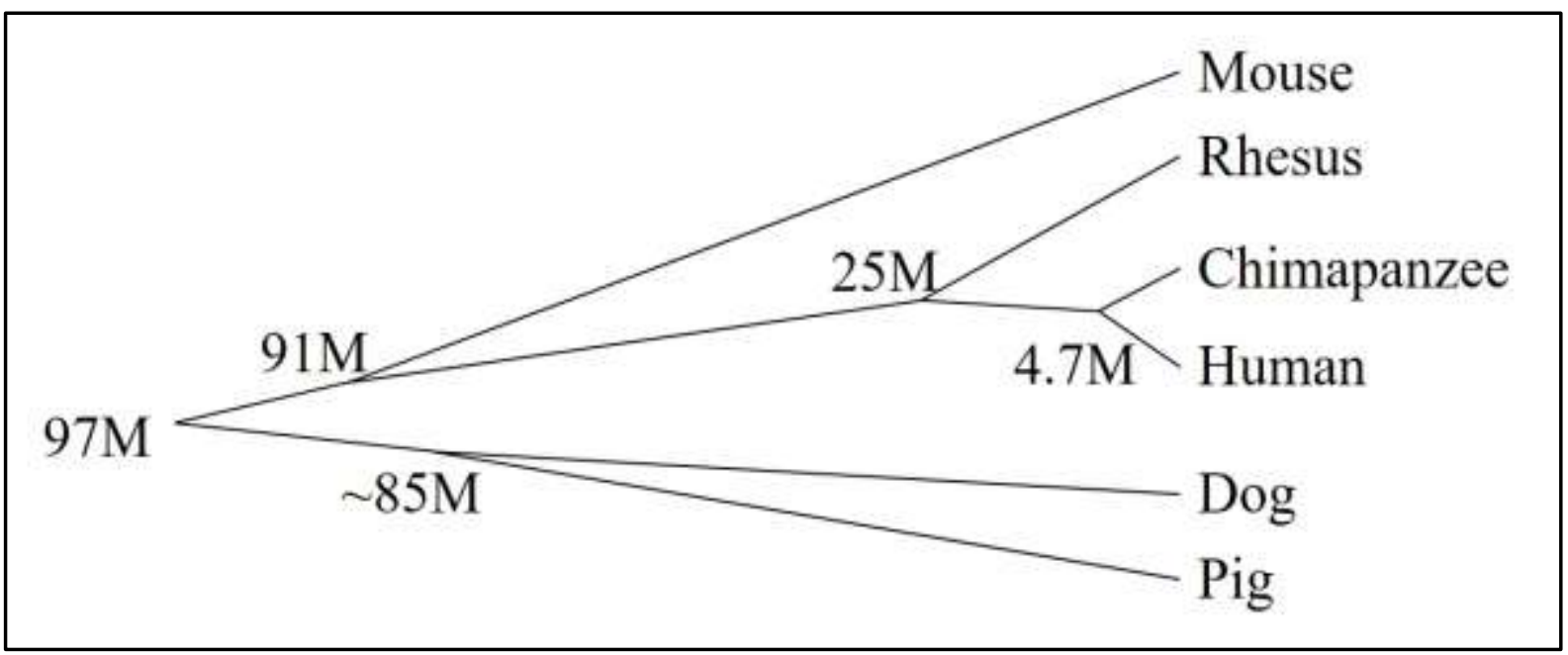

Figure 7: Evolutionary distance of mammalian test models

Humans and chimpanzees belong to the Family Hominidae with the other Great Apes and share the closet genetic similarities. Since 1999 Great apes have not been used in Europe for scientific research. Therefore, the evolutionary distance of 25 million years between the Rhesus macaque and human make them the most closely related mammalian species available for large animal model testing.

Macaques ( $M$. mulatta [rhesus macaque], $M$. fascicularis [crab-eating macaque], $M$. nemestrina [pig-tailed macaque]) are considered Old World monkeys and are the most widely used NHP for late preclinical studies (reviewed in Phillips et al. 2014). The Rhesus macaque is the best characterized macaque species with similar cardi- 
ovascular physiology compared to the human (Table 2) and shares $97 \%$ of its genome sequence with the human (Rogers and Gibbs 2014). Macaques have been used extensively as an alternative human model for infectious diseases (reviewed in Gardner and Luciw 2008), gene therapy (Lozier et al. 1999), cancer research (Brewer et al. 2001), reproduction (Lee et al. 2011, Nichols et al. 2010, VandeVoort et al. 2015), neurosciences (Bjugstad et al. 2008, Morin et al. 2014), and heart research (Bel et al. 2010, Chong et al. 2014, Kawamura et al. 2016, Shiba et al. 2016).

\begin{tabular}{|l|c|c|c|}
\hline & Heart weight (grams) & Heart beats/minute & Systolic pressure \\
\hline Human & $360-480$ & $60-90$ & $60-120 \mathrm{mmHg}$ \\
\hline Mouse & $0.14-0.15$ & $500-600$ & $80-160 \mathrm{mmHg}$ \\
\hline Rabbit & $9-11$ & $120-300$ & $70-170 \mathrm{mmHg}$ \\
\hline Dog & $160-420$ & $60-120$ & $120-150 \mathrm{mmHg}$ \\
\hline Pig & $400-500$ & $65-75$ & $70-130 \mathrm{mmHg}$ \\
\hline Sheep & $240-360$ & $70-80$ & $80-120 \mathrm{mmHg}$ \\
\hline Rhesus (Small) & $30-40$ & $125-240$ & $122-194 \mathrm{mmHg}$ \\
\hline Rhesus (Large) & $36-48$ & $95-235$ & $68-172 \mathrm{mmHg}$ \\
\hline
\end{tabular}

Table 2: Comparative heart anatomy and physiological data between human and common heart disease animal models

Rhesus data from Max Planck Institute for Biological Cybernetics: http://hirnforschung.kyb.mpg.de/fileadmin/uploads/files/Methoden/Bet\%C3\%A4ubun gsverfahren_und_Chirurgie/SOP_About_Monkeys.pdf (table modified from Gandolfi et al. 2011) 


\subsection{Dissertation Objectives}

Human stem cells have been successfully used as a source to generate cardiomyocytes for tissue engineering applications (Tiburcy et al. 2017). Due to the significant similarities between Rhesus macaque and humans, it is postulated that Rhesus induced pluripotent stem (RhiPS) cells can be directly differentiated into cardiomyocytes for future use in preclinical testing of myocardial infarction repair strategies. As an alternative and potentially immunologically more compatible stem cell source for allografting, methods to derived parthenogenetic stem cells were explored.

The following hypotheses were tested:

1. Cardiomyocytes can be differentiated effectively from Rhesus macaque iPS cells.

2. EHM with functional properties of native myocardium and similar properties to human EHM can be constructed from Rhesus macaque iPS cells.

3. Pluripotent parthenogenetic stem cells can be generated from unfertilized, superovulated Rhesus macaque oocytes. 


\section{Materials and Methods}

Materials used in this research that are not listed under each section can be found in the Appendix.

\subsection{Animal experiments}

Animal experiments - oocyte harvest from Rhesus macaque at the German Primate Center (DPZ) - were approved by the Niedersächsisches Landesamt für Verbraucherschutz und Lebensmittelsicherheit (LAVES - 33.9-42502-04-13/1363). Animal care was provided the veterinarians (Dr. med. vet. Charis Drummer and Sophie Mißbach) and animal care takers (Daniel Aschoff, Philip Rose and Carina Hunger) at the DPZ. Dr. med. vet. Charis Drummer and Sophie Mißbach performed all surgeries.

\subsubsection{Superovulation of Rhesus Macaque (Macaca mulatta)}

Five female rhesus macaques (Table 3 ) were caged individually or in pairs in the same room with a $0600-1800$ light cycle and maintained at a temperature of 25-27 ${ }^{\circ} \mathrm{C}$ at the DPZ animal housing facility.

\begin{tabular}{|c|c|c|}
\hline Animal number & Years of age & Body weight $(\mathrm{kg})$ \\
\hline 2483 & 6.5 & $4.9-5.5$ \\
\hline 2616 & 4.6 & $5.1-5.6$ \\
\hline 2500 & 5.8 & $6.5-6.9$ \\
\hline 2506 & 5.8 & $7.0-7.5$ \\
\hline 2551 & 5.0 & $5.3-5.6$ \\
\hline
\end{tabular}

Table 3: Female Rhesus macaques used for superovulation and oocyte harvest.

The cages were positioned to enable socialization with each other. Animals were provided food and water ad libitum. Seasonal produce, seeds, and cereal were offered as supplements for environmental enrichment. Females were observed daily for signs of vaginal bleeding and individual menstrual cycles were recorded by the animal care takers at the DPZ to identify the optimal time-point for superovulation 
treatment. The first sign of bleeding was assigned as "menses cycle day 1". Hormone injection (injection day 0 ) was done as outlined below on menses cycle day 1 , 2, 3 or 4 depending upon scheduling for the oocyte aspiration procedure. During superovulation cycle 1 all macaques received 37.5 International Units (IU) of recombinant human FSH (hFSH; Gonal F, 75 IU, Merck Serono) was administered intramuscularly (IM) twice daily for 6-8 days starting on injection day 0 . For super ovulation cycles 2 and 3, Rhesus macaques greater than 6 kilograms received 37.5 International Units (IU) of recombinant human FSH (hFSH; Gonal F, 75 IU, Merck Serono) IM twice daily for 6-8 days starting on injection day 0 . Rhesus macaques less than 6 kilograms were administered $18.75 \mathrm{IU}$ of recombinant hFSH IM, twice daily for 6-8 days starting on injection day 0 . Optimal stimulation of ovaries was identified, via ultrasound observation, as a total of 10 follicles with size measurements greater than $6 \mathrm{~mm} /$ follicle (Trounson et al. 2001). Once optimal stimulation was established and regardless of weight, an injection of 1,000 IU of recombinant human chorionic gonadotropin (hCG; Ovitrelle 250mg, Merck Serono) was administered IM, 24-36 hours before scheduled ovarian follicle aspiration ( 2 cycles) or ovariectomy ( $3^{\text {rd }}$ cycle). UItrasound (General electric-“Logiq-e" with $8 \mathrm{MHZ}$ probe) guided transabdominal aspiration of the follicles to retrieve oocytes and ovariectomy were both performed by primate veterinarians in a surgical operating room while the animals were under general anesthesia. Anesthesia plans were designed for each animal individually by DPZ veterinarians (Appendix A7).

\subsubsection{Collection of oocytes via follicle aspiration}

Between 24-36 hours after hCG injection, macaques were anesthetized by intramuscular ketamine injection based on individual body weight (Appendix A7) and transported by large animal transporter (Petmate Vari Kennel) to the operating suite. Ovaries were located, photographed, and measured by ultrasound. Follicle aspiration was performed as previously described by Vandevoort et al (2003). Briefly, ovarian follicles were punctured using a single lumen IVF aspiration needle (Gynetics, Belgium) and oocytes were manually aspirated by vacuum suction with a $50 \mathrm{ml}$ syringe attached to the needle. Aspirated oocytes were collected in a $15 \mathrm{ml}$ polypropylene (PP) tube containing warm Tyrode's Albumin Lactate Pyruvate-4-(2-hydroxyethyl)-1piperazineethanesulfonic acid (TALP-HEPES; Table 4) and maintained at $>35^{\circ} \mathrm{C}$ in a heated specimen transport incubator (Cell-Trans 4016, Labotect). For parthenoge- 
netic induction and culture, oocytes were transferred to the Department of Degenerative Diseases at the DPZ.

\begin{tabular}{|c|c|c|c|c|}
\hline Component & MW & Final $[\mathrm{mmol} / \mathrm{L}]$ & $\mathrm{g} / 50 \mathrm{ml}$ & $\mathrm{g} / 100 \mathrm{ml}$ \\
\hline $\mathrm{NaCl}$ (Sigma S-9888) & 58.44 & 127 & 0.3710 & 0.7420 \\
\hline KCL (Sigma P-3911) & 74.55 & 3.16 & 0.0118 & 0.0236 \\
\hline $\mathrm{CaCL}_{2}{ }^{*} 2 \mathrm{H}_{2} \mathrm{O}$ Sigma C-7902) & 147.02 & 2.00 & 0.0147 & 0.0294 \\
\hline $\begin{array}{l}\mathrm{MgCl}_{2}{ }^{*} 6 \mathrm{H}_{2} \mathrm{O} \text { (Sigma M- } \\
2393)\end{array}$ & 203.30 & 0.60 & 0.0051 & 0.0102 \\
\hline Glucose (Sigma G-8270) & 180.16 & 5.00 & 0.0451 & 0.0901 \\
\hline $\begin{array}{l}\mathrm{NaH}_{2} \mathrm{PO}_{4}{ }^{*} \mathrm{H}_{2} \mathrm{O} \text { (Fisher } \\
\text { BP330-500) }\end{array}$ & 137.99 & 0.35 & 0.0024 & 0.0048 \\
\hline $\mathrm{NaHCO}_{3}($ Sigma S-8875) & 84.01 & 2.00 & 0.0084 & 0.0168 \\
\hline $\begin{array}{l}\text { HEPES - Na Salt (Sigma H- } \\
3784)\end{array}$ & 260.30 & 5.00 & 0.0651 & 0.1302 \\
\hline $\begin{array}{l}\text { HEPES - Free Acid (Sigma } \\
\text { H-4034) }\end{array}$ & 238.30 & 5.00 & 0.0596 & 0.1192 \\
\hline Penicillin G (Sigma P-7794) & & & 0.0030 & 0.0060 \\
\hline $\begin{array}{l}\text { Streptomycin Sulfate (Sigma } \\
\text { S-9137) }\end{array}$ & & & 0.0030 & 0.0060 \\
\hline $\begin{array}{l}\text { Na Lactate (60\% syrup) } \\
\text { (Sigma L-1375) }\end{array}$ & 112.10 & 13 & 0.0926 & 0.1852 \\
\hline PVA (Sigma P-8136) & $\begin{array}{l}30,000- \\
70,000\end{array}$ & $0.1 \mathrm{mg} / \mathrm{ml}$ & 0.0050 & 0.0100 \\
\hline
\end{tabular}

\section{Table 4: TALP-HEPES medium for follicle aspiration.}

Combine all components in $90 \%$ of total volume in embryo tested water. Osmolarity was measured on an osmometer (Advanced Instruments Model 3320). Osmolarity was adjusted 290 mOsm by adding embryo tested water calculated by [(current osmolarity/290) $x$ current volume] = total volume. Total volume - current volume $=$ volume of embryo tested water to be added. The $\mathrm{pH}$ was measured using a $\mathrm{pH}$ meter (WTW model $\mathrm{pH} 323$ ) and adjusted to $7.4 \pm 0.05$ with the addition of $1 \mathrm{~N}$ Sodium 
Chloride (Roth K025.1) or $1 \mathrm{~N}$ Sodium Hydroxide (Roth K021.1). Medium was passed through a $0.22 \mu \mathrm{m}$ syringe filter. Modified from Boatman (1987).

\subsubsection{Collection of oocytes via ovariectomy}

Between 24-36 hours after hCG injection, macaques were anesthetized by ketamine injection (Appendix A6) and transported by animal transporter (Petmate Vari Kennel) to the operating suite. Ovaries were removed via midline incision and placed in a 15 $\mathrm{ml}$ PP tube containing warm TALP-HEPES and maintained at $\geq 35^{\circ} \mathrm{C}$ in a heated specimen transport incubator (Cell-Trans 4016, Labotect, Rosdorf, Germany). For parthenogenetic induction and culture, oocytes were transferred to the Institute of Pharmacology and Toxicology at the University Medical Center Göttingen. Ovaries were washed with warm TALP-HEPES and cumulus oocyte complexes (COCs) were manually dissected from the ovarian follicles with a scalpel under a laminar flow cell culture hood. COCs were collected in $6 \mathrm{~cm}$ culture dish containing TALP-HEPES and prepared for parthenogenetic activation (section 2.3.1).

\subsubsection{Collection of oocytes via necropsy}

Unstimulated ovaries were provided by the DPZ following euthanasia of a sixth female (\#2379) for medical reasons as determined by the veterinarians at the DPZ. Ovaries were collected in a $15 \mathrm{ml}$ PP tube containing warm phosphate buffered saline and maintained at $\geq 35^{\circ} \mathrm{C}$ in a heated specimen transport incubator (Cell-Trans 4016, Labotect, Rosdorf, Germany) and transferred to the Institute of Pharmacology and Toxicology at the University Medical Center Göttingen. Ovaries were washed with warm TALP-HEPES and COCs were manually dissected from the ovarian follicles with a scalpel under a laminar flow cell culture hood. COCs were collected in a 6 cm culture dish containing TALP-HEPES and prepared for in vitro maturation (IVM; Section 2.2.6).

\subsubsection{Teratoma assay}

Non-Obese Diabetic Severe Combined Immune Deficiency (NOD SCID) mice $(n=4)$ housed at the Institute for Human Genetics (Göttingen) were injected with $5 \times 10^{6}$ Sendai iPS cells in suspension in hES medium (Appendix A1) into the left flank of individual mice by Prof. Dr. Ralf Dressel. The hES medium was comprised of Dulbecco's modified eagle medium (DMEM; Invitrogen) supplemented with $20 \%$ Knock- 
out serum replacement (KOSR; Invitrogen) $100 \mathrm{U} / \mathrm{ml}$ Penicillin and $100 \mu \mathrm{g} / \mathrm{ml}$ Streptomycin and FGF-2 (10 ng/ml). Mice were monitored for the formation of tumors. Following formation of palpable tumors, mice were euthanized and tumors resected, weighed, and histological analysis was performed.

\subsection{Cell models}

Human and Rhesus macaque cells (fibroblasts and oocyte derived cells) were utilized. Human foreskin fibroblasts (hFF) were purchased from the American Type Culture Collection (SCRC-1041; ATCC). Rhesus embryonic stem cells (E366.4) were purchased from WiCell. Rhesus dermal (RhDFB) and gingiva fibroblasts (RhGFB) were obtained from the DPZ (Prof. R. Behr). Rhesus iPS cells were generated at the Institute of Pharmacology and Toxicology (Dr. M. Tiburcy) from a skin biopsy provided by the DPZ or at Stanford University (Dr. M. Wang/Prof. J. Wu) using retroviral or Sendai virus transduction of Yamanaka factors, respectively (Takahashi and Yamanaka 2006).

\subsubsection{Human foreskin fibroblasts}

hFFs were maintained in hFF medium consisting of Dulbecco's modified eagle medium (DMEM; Gibco) with $150 \mu \mathrm{l} / \mathrm{ml}$ of fetal bovine serum (FBS; PAA) and $100 \mathrm{U} / \mathrm{ml}$ Penicillin and $100 \mu \mathrm{g} / \mathrm{ml}$ Streptomycin (P/S; Invitrogen) and supplemented with 20 $\mathrm{ng} / \mathrm{ml}$ of fibroblast growth factor (FGF-2; Miltenyi Biotech). Multiple passages not exceeding passage 30 were used for all subsequent experiments.

\subsubsection{Rhesus fibroblasts}

Rhesus gingival fibroblasts (RhGFB) used for EHM production were isolated from biopsy of the buccal mucosa from a 15-year-old euthanized male from the DPZ. Additional gingival biopsies were obtained from five female Rhesus macaques undergoing surgical operations under anesthesia. Biopsies were transported from the surgery suite to the research facility in warm PBS with $100 \mathrm{U} / \mathrm{ml}$ Penicillin and $100 \mu \mathrm{g} / \mathrm{ml}$ Streptomycin and $2.5 \mu \mathrm{g} / \mathrm{ml}$ Amphotericin B. Biopsies were placed on a Synthemax (Corning) coated dish and cut into 1-2 mm pieces with a sharp scalpel and spread around dish to facilitate cellular outgrowth. Pieces were covered with serum and incubated for 30 minutes at $37^{\circ} \mathrm{C}$ and $5 \% \mathrm{CO}_{2}$ to ensure attachment of tissue to plate. Tissues were further incubated in hFF medium with $2.5 \mu \mathrm{g} / \mathrm{ml}$ Amphotericin B at 37 
${ }^{\circ} \mathrm{C}$ and $5 \% \mathrm{CO}_{2}$ for approximately 14 days with medium changes every other day. Once outgrowths from the primary biopsies began to appear, mechanical dissociation was performed and cells were propagate as described below.

\subsubsection{Fibroblast cell culture}

Primary fibroblasts (hFF, RhDFB or RhGFB) were cultured in hFF medium (section 2.2.1). Cultures were maintained in a humidified incubator at $37{ }^{\circ} \mathrm{C}$ and $5 \% \mathrm{CO}_{2}$. Routine passaging of fibroblasts was performed when confluency reached a maximum of $90 \%$ based on visual inspection. Cells were rinsed once with PBS (warmed to $37^{\circ} \mathrm{C}$ ). Cellular dissociation was performed using pre-warmed Tryple ${ }^{\mathrm{TM}}$ Express Enzymatic Dissociation Solution (ThermoFisher Scientific) for $2-5$ minutes at $37{ }^{\circ} \mathrm{C}$. Visual inspection of cell detachment was monitored with a light microscope during dissociation. Following the dissociation of the cells form the culture flask $2 x$ volumes of hFF medium were added and gently pipetted to ensure cell clumps were broken up into a single cell suspension. Dissociated cells were pelleted through centrifugation at $300 \mathrm{~g}$ for 5 minutes and resuspended in fresh medium. Cells were counted (section 2.6.1) and seeded onto new culture dishes at the required density, or used for EHM generation (section 2.5.2). Aliquots of fibroblasts were frozen in cryovials for storage purposes at concentrations of $3 \times 10^{6}$ in freezing medium $(90: 10 \%$ FBS:DMSO). Cell suspensions were transferred into cryovials $(1 \mathrm{ml}$ cell suspension/vial), and immediately placed into an insulated freezing container (Mr. Frosty, ThermoFisher Scientific) filled with isopropanol and placed at $-80{ }^{\circ} \mathrm{C}$, to freeze cells slowly enough to maintain viability. Previously frozen cells to be used for experiments were thawed rapidly in warm water bath followed by the addition of $1 \mathrm{ml}$ of fresh hFF medium (warmed to $37^{\circ} \mathrm{C}$ ) into the cryovial to resuspend the cells. Thawed cells were immediately transferred into $15 \mathrm{ml}$ PP tubes with additional warmed hFF medium and centrifuged at $300 \mathrm{~g}$ for 5 minutes at RT and resuspended in hFF medium, to remove DMSO. Cell suspensions were then plated accordingly to be used for subsequent experiments requiring fibroblast feeder layers for culturing.

\subsubsection{Preparation of fibroblast feeder layers}

Mitotically inactivated hFFs were used as feeder layers for standard culturing of undifferentiated Rhesus iPS cells. Culturing the stem cells on an inactivated fibroblast feeder layer provides a supportive environment for the Rhesus stem cells without 
dividing and diluting the cultivation of undifferentiated stem cells (Fuegemann et al. 2010, Soong et al. 2012, Wobus et al. 1991). Prior to use as a cell culture feeder layer hFFs were mitotically inactivated by $\mathrm{Y}$-irradiation (30 Gy). To produce large stocks of inactivated fibroblasts, hFFs were cultured in T175 culture flasks in hFF medium until a maximum of $90 \%$ confluency was reached. Fibroblasts were rinsed once with PBS (warmed to $37^{\circ} \mathrm{C}$ ) in a volume appropriate for the size of the culture flask. Cellular dissociation was performed using pre-warmed Tryple ${ }^{\mathrm{TM}}$ for 2-5 minutes at $37{ }^{\circ} \mathrm{C}$. Visual inspection of cell detachment was monitored with a light microscope during dissociation. Following the dissociation of the cells from the culture flask, $2 x$ volumes of hEF medium were added to stop the enzymatic reaction. Dissociated fibroblasts were transferred into a $50 \mathrm{ml}$ conical PP tube and centrifuged at $300 \mathrm{~g}$ for 5 minutes. After centrifugation cells were resuspended in fresh hFF medium and counted following the procedure found in section 2.6.1. Appropriate viable cell numbers $\left(2 \times 10^{6} / \mathrm{ml}\right)$, based on counting results, were transferred into new $15 \mathrm{ml}$ PP tubes prior to irradiation. Fibroblasts were exposed to one cycle of 30 Gy for 15 minutes. After irradiation, cell suspensions were counted again (section 2.6.1) and frozen down into cryovial stocks $\left(8 \times 10^{6}\right.$ cells $\left./ \mathrm{ml}\right)$ in freezing medium until further use or immediately plated at a seeding density of $40,000 / \mathrm{cm}^{2}$ in hEF medium.

\subsubsection{Preparation of Rhesus fibroblasts for engineered heart muscle}

Culturing of RhGFB was performed in T175 or T225 (Nunc) culture flasks to ensure sufficient numbers of fibroblasts for EHM construction. Culture flasks were coated with $10-15 \mathrm{ml}$ of $0.1 \%$ gelatin to facilitate cell attachment. Flasks were incubated for 20 minutes at $37{ }^{\circ} \mathrm{C}$ with $5 \% \mathrm{CO}_{2}$. Following solidification of gelatin, the remaining fluid component was aspirated. A cryovial of previously frozen cells was thawed by adding prewarmed hFF medium to the frozen pellet and gently pipetted. The medium and cells were transferred into a $15 \mathrm{ml}$ PP tube and centrifuged at $300 \mathrm{~g}$ for 5 minutes. Following centrifugation media was aspirated and the pellet was resuspended in warmed hFF media. Cells were counted using a CASY counter (section 2.6.1). An appropriate volume of cell suspension, based on viable cell content obtained from counting, was then pipetted into each flask, containing an appropriate volume of warmed hFF media plus FGF-2, at a density of 17,000 cells $/ \mathrm{cm}^{2}$. 


\subsubsection{In vitro maturation of Rhesus oocytes}

Rhesus oocytes were obtained from the DPZ following a routine necropsy. After manual dissection from the ovarian follicles COCs were incubated at $37^{\circ} \mathrm{C}$ in a humidified incubator with $5 \% \mathrm{CO}_{2}$ and $5 \% \mathrm{O}_{2}$ for 24 hours in IVM medium (Appendix A8). After IVM COCs were parthenogenetically activated (Section 2.3.1).

\subsection{Stem cells}

\subsubsection{Rhesus macaque parthenogenetic stem cells}

Rhesus parthenogenetic stem cell lines 2551 (RhpSC-2551) and 2616 (RhpSC2616) were generated via parthenogenetic activation of MII phase oocytes. Following aspiration of follicles (ovulation cycles 1 and 2), ovariectomy (ovulation cycle 3), or IVM (ovaries obtained from necropsy), oocytes were first exposed to $0.5 \mathrm{mg} / \mathrm{ml}$ hyaluronidase (Type IV; Sigma Aldrich) for 5-10 minutes to remove cumulus cells followed by three washes with TALP-Hepes medium. After cumulus cell removal, all oocytes were subjected to a five-minute incubation with a calcium ionophore, lonomycin ( $5 \mathrm{mmol} / \mathrm{L}$, Sigma), followed by either 4-hour incubation with 6-DMAP (1 $\mathrm{mmol} / \mathrm{L}$; Sigma Aldrich; ovulation cycle 1) or a 5-hour incubation with puromycin (5 $\mu \mathrm{g} / \mathrm{ml}$; Gibco; ovulation cycles 2 and 3 ) at $37{ }^{\circ} \mathrm{C}$ in a humidified incubator with $5 \%$ $\mathrm{CO}_{2}$ and $5 \% \mathrm{O}_{2}$. All activation chemicals were prepared in Hamster Embryo Culture Medium 9 (HECM-9) base medium (Table 5). After activation oocytes from ovulation cycles 1 and 2 were transferred into drops of HECM-9 medium covered by mineral oil (or liquid paraffin) and incubated at $37{ }^{\circ} \mathrm{C}$ in a humidified incubator with $5 \% \mathrm{CO}_{2}$ and $5 \% \mathrm{O}_{2}$. Oocytes were transferred to a fresh HECM-9 medium drop after the first 18-20-hours post activation and then every 48 hours until blastocyst formation was observed. Prior to transferring, photos were taken using Zeiss Discovery V8 and Octax Eyeware software. Following activation, oocytes from ovulation cycle 3 were incubated using a Vitrolife Embryoscope ${ }^{\mathrm{TM}}$. Oocytes remained in the original drop of HECM-9 medium for the duration of culture and images were automatically obtained via the embryoscope software program every 30-45 minutes until morula/blastocyst stage was achieved. Mature metaphase II (MII) oocytes that were successfully activated and developed to morula stage or further were removed from culture and plated on feeder layers. 


\begin{tabular}{|l|l|l|l|l|}
\hline Component & MW & Final [mmol/L] & $\mathbf{g} / \mathbf{5 0} \mathbf{~ m l}$ & $\mathbf{g} / \mathbf{1 0 0} \mathbf{~ m l}$ \\
\hline $\mathrm{NaCl}$ (Sigma S-9888) & 58.44 & 127 & 0.3710 & 0.7420 \\
\hline $\mathrm{KCL}$ (Sigma P-3911) & 74.55 & 3.16 & 0.0118 & 0.0236 \\
\hline $\mathrm{CaCL}_{2}{ }^{*} \mathrm{H}_{2} \mathrm{O}$ Sigma C-7902) & 147.02 & 2.00 & 0.0147 & 0.0294 \\
\hline $\begin{array}{l}\mathrm{MgCl}_{2}{ }^{*} 6 \mathrm{H}_{2} \mathrm{O} \text { (Sigma M- } \\
2393)\end{array}$ & 203.30 & 0.60 & 0.0051 & 0.0102 \\
\hline $\mathrm{NaHCO}_{3}$ (Sigma S-8875) & 84.01 & 2.00 & 0.0084 & 0.0168 \\
\hline $\begin{array}{l}\text { Na Lactate (60\% syrup) } \\
(\text { Sigma L-1375) }\end{array}$ & 112.10 & 13 & 0.0926 & 0.1852 \\
\hline $\begin{array}{l}\mathrm{PVA} \text { (Sigma P-8136) } \\
1 \mathrm{~N} \mathrm{HCL} \mathrm{solution}\end{array}$ & $\begin{array}{l}30,000- \\
70,000\end{array}$ & $0.1 \mathrm{mg} / \mathrm{ml}$ & 0.0050 & 0.0100 \\
\hline
\end{tabular}

Table 5: HECM-9 medium for oocyte activation and culture.

Combine all components in $90 \%$ of total volume in embryo tested water. Osmolarity was measured on an osmometer (Advanced Instruments Model 3320). Osmolarity was adjusted $290 \mathrm{mOsm}$ by adding embryo tested water calculated by [(current osmolarity/290) $\times$ current volume] $=$ total volume. The $\mathrm{pH}$ was measured using a $\mathrm{pH}$ meter (WTW model pH 323) and adjusted to $7.4 \pm 0.05$ with the addition of $1 \mathrm{~N}$ Sodium Chloride (Roth K025.1) or $1 \mathrm{~N}$ Sodium Hydroxide (Roth K021.1). Combine with 100X AA/P solution before use (Table 6). 


\begin{tabular}{|l|l|l|l|l|}
\hline Component & Sigma Catalog \# & MW & $\begin{array}{l}\text { Final concentration } \\
\text { [mmol/L] }\end{array}$ & $\mathbf{g} / \mathbf{1 0} \mathbf{~ m l}$ \\
\hline Taurine & T-8691 & 125.1 & 0.50 & 0.0626 \\
\hline Asparagine & A-4159 & 132.1 & 0.01 & 0.0013 \\
\hline Cysteine & C-6852 & 175.6 & 0.01 & 0.0018 \\
\hline Histidine & H-5659 & 209.6 & 0.01 & 0.0021 \\
\hline Lysine & L-8662 & 182.6 & 0.01 & 0.0018 \\
\hline Proline & P-5607 & 115.1 & 0.01 & 0.0012 \\
\hline Serine & S-4311 & 105.1 & 0.01 & 0.0011 \\
\hline Aspartic Acid & A-4534 & 133.1 & 0.01 & 0.0013 \\
\hline Glycine & G-8790 & 75.07 & 0.01 & 0.0008 \\
\hline Glutamic Acid & G-5889 & 169.1 & 0.01 & 0.0017 \\
\hline Glutamine & G-8540 & 146.1 & 0.20 & 0.0292 \\
\hline $\begin{array}{l}\text { Pantothenic } \\
\text { Acid }\end{array}$ & P-5155 & 238.3 & 0.003 & 0.0007 \\
\hline
\end{tabular}

Table 6: Amino acid/Pantothenate solution for oocyte activation and culture Combine with 10 milliliters of embryo tested water. Add $10 \mu \mathrm{l}$ per $1 \mathrm{ml}$ of HECM-9 medium.

Successfully activated Rhesus oocytes that progressed to the morula stage or further, were transferred onto fibroblast feeder cultures in attempt to propagate a cell line. To do so, morula stage cells were briefly exposed to $0.5 \%$ pronase to degrade the zona pellucida. Degradation was directly observed under a dissecting microscope and morulae were gently pipetted until the central aggregation of blastomeres was released from the degrading zona pellucida. The blastomeres were then immediately transferred onto fibroblast feeder cultures in hES medium supplemented with

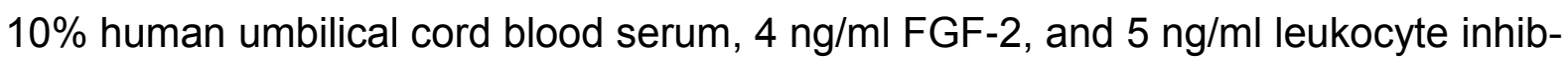
iting factor (LIF; cycle 1; Revazova et al. 2007) and incubated at $37^{\circ} \mathrm{C}$ and $5 \% \mathrm{O}_{2}$. The blastomere culture medium was amended with the increase of FGF-2 to 10 $\mathrm{ng} / \mathrm{ml}$ for cycles 2 and 3 . Following transfer onto mitotically inactivated human fibro- 
blast feeder cells, RhpSC 2551 (cycle 3) blastomere outgrowths began to spontaneously differentiate. Therefore, reprogramming of the cells was performed using the Cytotune 2.0 Sendai virus reprogramming kit (ThermoFisher Scientific). Blastomere outgrowths from RhpSC 2616 (cycle 3) proceeded normally. No blastomeres from cycles 1 or 2 generated successful outgrowths on feeder cultures.

\subsubsection{Rhesus Induced Pluripotent Stem Cell line C1}

Rhesus induced pluripotent stem cell line C1 (C1) was generated by Dr. Malte Tiburcy at the Institute of Pharmacology and Toxicology, University Medical Center Göttingen, using six factor lentiviral reprogramming with OCT4, SOX2, KLF4, c-MYC, LIN28 and NANOG (=OSKMLN; unpublished). OSKM were encoded on a STEMCAA vector (Somers et al. 2010). Nanog and Lin 28 were contained on two additional lentiviral vectors, pSin-EF2-Nanog-Pur and pSin-EF2-Lin28-Pur (Yu et al. 2007), respectively.

\subsubsection{Rhesus Induced Pluripotent Stem Cell line 43110-4}

Rhesus induced pluripotent stem cell line 43110-4 (Sendai) was generated in the laboratory of Dr. Joseph Wu at Stanford University using Cytotune 2.0 (Thermo Fisher) Sendai viral reprogramming kit and generously provided for use in this project.

\subsubsection{Stem cell culture}

Rhesus stem cell cultures were cultured on inactivated hFF cell feeder layers in hES medium. Cultures were maintained in a humidified incubator at $37{ }^{\circ} \mathrm{C}$ and $5 \% \mathrm{CO}_{2}$. Routine passaging of stem cells was performed when confluency reached a maximum of $90 \%$ based on visual inspection. Cells were rinsed once with PBS (warmed to $37^{\circ} \mathrm{C}$ ) in a volume appropriate for the size of the culture dish. Cellular dissociation was performed using pre-warmed Tryple ${ }^{\mathrm{TM}}$ for $2-5$ minutes at $37^{\circ} \mathrm{C}$. Visual inspection of cell detachment was monitored with a light microscope during dissociation. Following the dissociation of the cells from the culture flask $2 x$ volumes of hES medium were gently added ensuring that stem cells and fibroblasts were removed in an intact sheet. The cell sheet was gently agitated in the medium to free any loose stem cells without too many fibroblasts in cell suspension. Medium with stem cells was gently pipetted into PP tubes, making sure to leave the fibroblast cell sheet behind. 
Dissociated cells were pelleted through centrifugation at $300 \mathrm{~g}$ for 5 minutes and resuspended in fresh hES medium. Cells were counted using a CASY counter (section 2.6.1) and seeded onto new fibroblast feeders at the required density or used for EHM generation (section 2.5.2). Aliquots of dissociated stem cells were frozen in cryovials and stored until further use. Cells were re-suspended at a concentration of $2 \times 10^{6}$ cells $/ \mathrm{ml}$ in freezing medium and transferred into cryovials $(1 \mathrm{ml} / \mathrm{vial})$ and immediately placed in an insulated freezing container (Mr. Frosty, ThermoFisher Scientific) and placed at $-80^{\circ} \mathrm{C}$, to freeze cells slowly enough to maintain viability. Frozen cells to be used for experiments were thawed rapidly at $37^{\circ} \mathrm{C}$ and washed in $1 \mathrm{ml}$ of fresh hES medium (warmed to $37^{\circ} \mathrm{C}$ ). Thawed cells were immediately transferred into $15 \mathrm{ml}$ PP tubes with additional warmed medium and centrifuged at $300 \mathrm{~g}$ for 5 minutes at RT to remove DMSO. Supernatant was removed and the cell pellet was resuspended in hES medium. Cell suspensions were then plated onto hFF feeders and cultured in hES medium with FGF-2 $(10 \mathrm{ng} / \mathrm{ml})$ in a humidified incubator at $37^{\circ} \mathrm{C}$ and $5 \% \mathrm{CO}_{2}$.

\subsubsection{Rhesus Mamu sequencing}

Cell cultures of Lenti- and Sendai-iPS lines were provided to Prof. Dr. Lutz Walter at the DPZ Department of Primate Genetics for MHC Class I and Class II Mamu screening. Sendai iPS cell-derived cardiomyocytes were treated with $100 \mathrm{units} / \mathrm{ml}$ recombinant human interferon gamma (IFNy, peprotech; Suarez-Alvarez et al. 2010) or $50 \mu \mathrm{g} / \mathrm{ml}$ lipopolysaccharides (LPS; Sigma-Aldrich) for 24 hours at $37^{\circ} \mathrm{C}$ in a humidified incubator with $5 \% \mathrm{CO}_{2}$ to elicit MHC Class I Mamu overexpression. RNA was isolated from the cell cultures and amplified by PCR by Nico Westphal from the Walter Lab at the DPZ and sequenced at the Transcriptome and Genome Analysis Laboratory (TAL Göttingen). Total RNA was extracted from cells using the following Trizol protocol. Cells were removed from culture flasks using a cell scraper and collected in a $1.5 \mathrm{ml}$ tube. $360 \mu \mathrm{l}$ of TRIzol Reagent was added to the tube cells were pipetted up and down to homogenize them. Homogenized samples were incubated for 5 minutes at RT to dissociate the cells and then centrifuged at $12,000 \mathrm{~g}$ for 10 minutes at $4{ }^{\circ} \mathrm{C}$. Supernatant was transferred to a fresh $1.5 \mathrm{ml}$ tube and $72 \mu \mathrm{l}$ of chloroform was added to the tube and vortexed for 30 seconds. Samples were centrifuged at $12,000 \mathrm{~g}$ for 15 minutes at $4{ }^{\circ} \mathrm{C}$. Following centrifugation, the aqueous phase (upper phase) containing the RNA was transferred into a fresh $1.5 \mathrm{ml}$ tube. 
Precipitation of the RNA from the aqueous phase was achieved by adding $180 \mu \mathrm{l}$ of isopropyl-alcohol (isopropanol) and $1 \mu$ l Glyco blue to the sample. Samples were vortexed and precipitated overnight at $-20^{\circ} \mathrm{C}$. Following overnight precipitation samples were centrifuged at $12,000 \mathrm{~g}$ for $45-55$ minutes at $4^{\circ} \mathrm{C}$. After centrifugation, supernatant was removed with a pipette and the pellet was washed with $0.5 \mathrm{ml}$ of $75 \%$ $\mathrm{EtOH}$ and centrifuged at $12,000 \mathrm{~g}$ for 10 minutes at $4{ }^{\circ} \mathrm{C}$. After centrifugation, the supernatant was removed with a pipette and the pellet was washed with $0.5 \mathrm{ml}$ of $75 \% \mathrm{EtOH}$ and centrifuged at $12,000 \mathrm{~g}$ for 10 minutes at $4{ }^{\circ} \mathrm{C}$. After centrifugation, the supernatant was removed with a pipette and the pellet dried at $37^{\circ} \mathrm{C}$. The dried RNA pellet was dissolved in 10-20 $\mu$ of RNase free water and mixed by pipetting and stored at $-80^{\circ} \mathrm{C}$. A $5 \mu$ l sample was checked for quality and quantity.

Amplification of the MHC Class I RNA was performed with cDNA generated using a Transcriptor high fidelity cDNA synthesis kit from Roche according to the manufacturer's instructions. PCR reaction used the primers listed in Table 7A for MHC Class I and primers from Table 8A for MHC Class II with FastStart ${ }^{\mathrm{TM}}$ High Fidelity PCR System polymerase (Roche). Amplification of MHC Class I was performed according to Table 7B. Amplification of MHC Calls II was performed according to table 8B. Following amplification of the cDNA libraries, PCR products were purified with the MinElute PCR purification kit (Qiagen) and combined into pooled samples with concentrations of $10 \mathrm{nmol} / \mathrm{L}$ and sequenced on a Miseq sequencer (Illumina) at the TAL Göttingen.

\begin{tabular}{|c|l|l|c|}
\hline $\begin{array}{c}\text { Gene } \\
\text { transcripts }\end{array}$ & \multicolumn{1}{|c|}{ Forward primer } & \multicolumn{1}{c|}{ Reverse primer } & Base Pairs \\
\hline MHC I & $\begin{array}{l}\text { 5'-GCT ACG TGG ACG } \\
\text { ACA CG -3' }\end{array}$ & $\begin{array}{l}\text { 5'-TCC CAC TTS CGC } \\
\text { TGG GT-3' }\end{array}$ & $\begin{array}{l}\text { F }=17 \\
\mathrm{R}=17\end{array}$ \\
\hline
\end{tabular}

Table 7A: Oligonucleotide sequences for Rhesus MHC class I PCR amplification

\begin{tabular}{|c|c|c|c|}
\hline Cycle Step & Temperature & Time & Cycles \\
\hline Initial Denaturation & $95^{\circ} \mathrm{C}$ & 5 minutes & \\
\hline
\end{tabular}




\begin{tabular}{|c|c|c|c|}
\hline Denaturation & $95^{\circ} \mathrm{C}$ & 15 seconds & \multirow{2}{*}{$35 \times$} \\
\cline { 1 - 3 } Annealing & $52^{\circ} \mathrm{C}$ & 45 seconds & \\
\hline Extension & $72^{\circ} \mathrm{C}$ & 45 seconds & \\
\hline Final extension & $72^{\circ} \mathrm{C}$ & 5 minutes & $1 \mathrm{X}$ \\
\hline
\end{tabular}

Table 7B: Amplification program for MHC Class I

\begin{tabular}{|c|c|c|c|}
\hline Gene & Forward primer & Reverse primer & Base Pairs \\
\hline DPA-1 & $\begin{array}{lll}\text { 5'- CGT ATC GCC } & \text { TCC } \\
\text { CTC GCG CCA } & \text { TCA } \\
\text { GAC GAG TGC } & \text { GTA } \\
\text { TGC GCC CTG } & \text { AAG } \\
\text { ACA GAA TGT -3' } & \end{array}$ & $\begin{array}{l}\text { 5'- CTA TGC GCC TTG } \\
\text { CCA GCC CGC TCA } \\
\text { GAC GAG TGC GTC } \\
\text { CCC TGG GCM CGG } \\
\text { GG -3' }\end{array}$ & $\begin{array}{l}F=57 \\
R=50\end{array}$ \\
\hline DPA-2 & $\begin{array}{l}\text { 5'- CGT ATC GCC TCC } \\
\text { CTC GCG CCA TCA } \\
\text { GAC GCT CGA CAA } \\
\text { TGC GCC CTG } \\
\text { ACA GAA TGT }-3 \text { ' }\end{array}$ & $\begin{array}{l}\text { 5'- CTA TGC GCC TTG } \\
\text { CCA GCC CGC TCA } \\
\text { GAC GCT CGA CAC } \\
\text { CCC TGG GCM CGG } \\
\text { GG -3. }\end{array}$ & $\begin{array}{l}F=57 \\
R=50\end{array}$ \\
\hline DPA-3 & $\begin{array}{lll}\text { 5'-CGT ATC } & \text { GCC } & \text { TCC } \\
\text { CTC GCG CCA } & \text { TCA } \\
\text { GAG ACG CAC } & \text { TCA } \\
\text { TGC GCC CTG } & \text { AAG } \\
\text { ACA GAA TGT }-3 \text { ' } & \end{array}$ & $\begin{array}{l}\text { 5'-CTA TGC GCC TTG } \\
\text { CCA GCC CGC TCA } \\
\text { GAG ACG CAC TCC } \\
\text { CCC TGG GCM-3' } \\
\text { CGG GG -3' }\end{array}$ & $\begin{array}{l}F=57 \\
R=50\end{array}$ \\
\hline DPA-4 & $\begin{array}{l}\text { 5'- CGT ATC GCC TCC } \\
\text { CTC GCG CCA TCA } \\
\text { GAG CAC TGT AGA } \\
\text { TGC GCC CTG AAG } \\
\text { ACA GAA TGT -3', }\end{array}$ & $\begin{array}{l}\text { 5'- CTA TGC GCC TTG } \\
\text { CCA GCC CGC TCA } \\
\text { GAG CAC TGT AGC } \\
\text { CCC TGG GCM CGG } \\
\text { GG-3' }\end{array}$ & $\begin{array}{l}F=57 \\
R=50\end{array}$ \\
\hline DPB-1 & $\begin{array}{llll}\text { 5'- CGT ATC } & \text { GCC } & \text { TCC } \\
\text { CTC } & \text { GCG } & \text { CCA } & \text { TCA } \\
\text { GAC } & \text { GAG } & \text { TGC } & \text { GTA } \\
\text { TGA } & \text { TGG } & \text { TTC } & \text { TGS }\end{array}$ & $\begin{array}{llll}\text { 5'- CTA TGC GCC TTG } \\
\text { CCA GCC } \\
\text { GAC } & \text { TCA } \\
\text { TAT GCA } & \text { GAT } & \text { CCT }\end{array}$ & $\begin{array}{l}F=57 \\
R=60\end{array}$ \\
\hline
\end{tabular}




\begin{tabular}{|c|c|c|c|}
\hline & AGG TWT CTG -3' & CGT TGA ACT TTC -3' & \\
\hline DPB-2 & $\begin{array}{lll}\text { 5'- CGT ATC GCC TCC } \\
\text { CTC GCG CCA TCA } \\
\text { GAC GCT CGA CAA } \\
\text { TGA TGG TTC TGS } \\
\text { AGG TWT CTG -3' } \\
\end{array}$ & $\begin{array}{l}\text { 5'- CTA TGC GCC TTG } \\
\text { CCA GCC CGC TCA } \\
\text { GAC GCT CGA CAT } \\
\text { TAT GCA GAT CCT } \\
\text { CGT TGA ACT TTC -3' }\end{array}$ & $\begin{array}{l}F=57 \\
R=60\end{array}$ \\
\hline DPB-3 & $\begin{array}{lll}\text { 5'- CGT ATC GCC TCC } \\
\text { CTC GCG CCA TCA } \\
\text { GAG ACG CAC TCA } \\
\text { TGA TGG TTC TGS } \\
\text { AGG TWT CTG -3' } \\
\end{array}$ & $\begin{array}{l}\text { 5'- CTA TGC GCC TTG } \\
\text { CCA GCC CGC TCA } \\
\text { GAG ACG CAC TCT } \\
\text { TAT GCA GAT CCT } \\
\text { CGT TGA ACT TTC -3' }\end{array}$ & $\begin{array}{l}F=57 \\
R=60\end{array}$ \\
\hline DPB-4 & $\begin{array}{lll}\text { 5'- CGT ATC GCC TCC } \\
\text { CTC GCG CCA TCA } \\
\text { GAG CAC TGT AGA } \\
\text { TGA TGG TTC TGS } \\
\text { AGG TWT CTG }-3^{\prime}\end{array}$ & $\begin{array}{l}\text { 5'- CTA TGC GCC TTG } \\
\text { CCA GCC CGC TCA } \\
\text { GAG CAC TGT AGT } \\
\text { TAT GCA GAT CCT } \\
\text { CGT TGA ACT TTC -3' }\end{array}$ & $\begin{array}{l}\mathrm{F}=57 \\
\mathrm{R}=60\end{array}$ \\
\hline DQA-1 & $\begin{array}{l}\text { 5'- CGT ATC GCC TCC } \\
\text { CTC GCG CCA TCA } \\
\text { GAC GAG TGC GTA } \\
\text { TGA TCC TAA ACA AAG } \\
\text { CTC TG }-3 \text { ', }\end{array}$ & $\begin{array}{l}\text { 5'- CTA TGC GCC TTG } \\
\text { CCA GCC CGC TCA } \\
\text { GAC GAG TGC GTT } \\
\text { GGT GTC TGG ARG } \\
\text { CAC CAA CTG -3' }\end{array}$ & $\begin{array}{l}F=56 \\
R=57\end{array}$ \\
\hline DQA-2 & $\begin{array}{l}\text { 5'- CGT ATC GCC TCC } \\
\text { CTC GCG CCA TCA } \\
\text { GAC GCT CGA CAA } \\
\text { TGA TCC TAA ACA AAG } \\
\text { CTC TG -3' } \\
\end{array}$ & 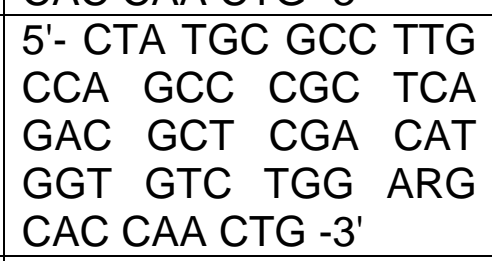 & $\begin{array}{l}F=56 \\
R=57\end{array}$ \\
\hline DQA-3 & $\begin{array}{l}\text { 5'- CGT ATC GCC TCC } \\
\text { CTC GCG CCA TCA } \\
\text { GAG ACG CAC TCA } \\
\text { TGA TCC TAA ACA AAG } \\
\text { CTC TG -3' }\end{array}$ & $\begin{array}{l}\text { 5'- CTA TGC GCC TTG } \\
\text { CCA GCC CGC TCA } \\
\text { GAG ACG CAC TCT } \\
\text { GGT GTC TGG ARG } \\
\text { CAC CAA CTG -3' }\end{array}$ & $\begin{array}{l}\mathrm{F}=56 \\
\mathrm{R}=57\end{array}$ \\
\hline DQA-4 & $\begin{array}{l}\text { 5'- CGT ATC GCC TCC } \\
\text { CTC GCG CCA TCA } \\
\text { GAG CAC TGT AGA } \\
\text { TGA TCC TAA ACA AAG } \\
\text { CTC TG }-3^{\prime}\end{array}$ & $\begin{array}{l}\text { 5'- CTA TGC GCC TTG } \\
\text { CCA GCC CGC TCA } \\
\text { GAG CAC TGT AGT } \\
\text { GGT GTC TGG ARG } \\
\text { CAC CAA CTG }-3^{\prime}\end{array}$ & $\begin{array}{l}F=56 \\
R=57\end{array}$ \\
\hline DQB-1 & $\begin{array}{l}\text { 5'- CGT ATC GCC TCC } \\
\text { CTC GCG CCA } \\
\text { GAC GAG TGC } \\
\text { AAR ATG } \\
\text { CGG ATY CC }-3^{\prime}\end{array}$ & $\begin{array}{l}\text { 5'- CTA TGC GCC TTG } \\
\text { CCA GCC CGC TCA } \\
\text { GAC GAG TGC GTC } \\
\text { CCC AGC ACR ARG } \\
\text { CCT CC }-3^{\prime}\end{array}$ & $\begin{array}{l}F=56 \\
R=53\end{array}$ \\
\hline DQB-2 & $\begin{array}{lll}\text { 5'- CGT ATC GCC } & \text { TCC } \\
\text { CTC GCG CCA } & \text { TCA } \\
\text { GAC GCT CGA } & \text { CAG } \\
\text { AAR AAG } & \text { KCT } & \text { TTG } \\
\text { CGG ATY CC }-3^{\prime} & \end{array}$ & $\begin{array}{l}\text { 5'- CTA TGC GCC TTG } \\
\text { CCA GCC CGC TCA } \\
\text { GAC GCT CGA CAC } \\
\text { CCC AGC ACR ARG } \\
\text { CCT CC -3' }\end{array}$ & $\begin{array}{l}F=56 \\
R=53\end{array}$ \\
\hline DQB-3 & $\begin{array}{l}\text { 5'- CGT ATC GCC TCC } \\
\text { CTC GCG CCA TCA } \\
\text { GAG ACG CAC TCG }\end{array}$ & $\begin{array}{l}\text { 5'- CTA TGC GCC TTG } \\
\text { CCA GCC CGC TCA } \\
\text { GAG ACG CAC TCC }\end{array}$ & $\begin{array}{l}F=56 \\
R=53\end{array}$ \\
\hline
\end{tabular}




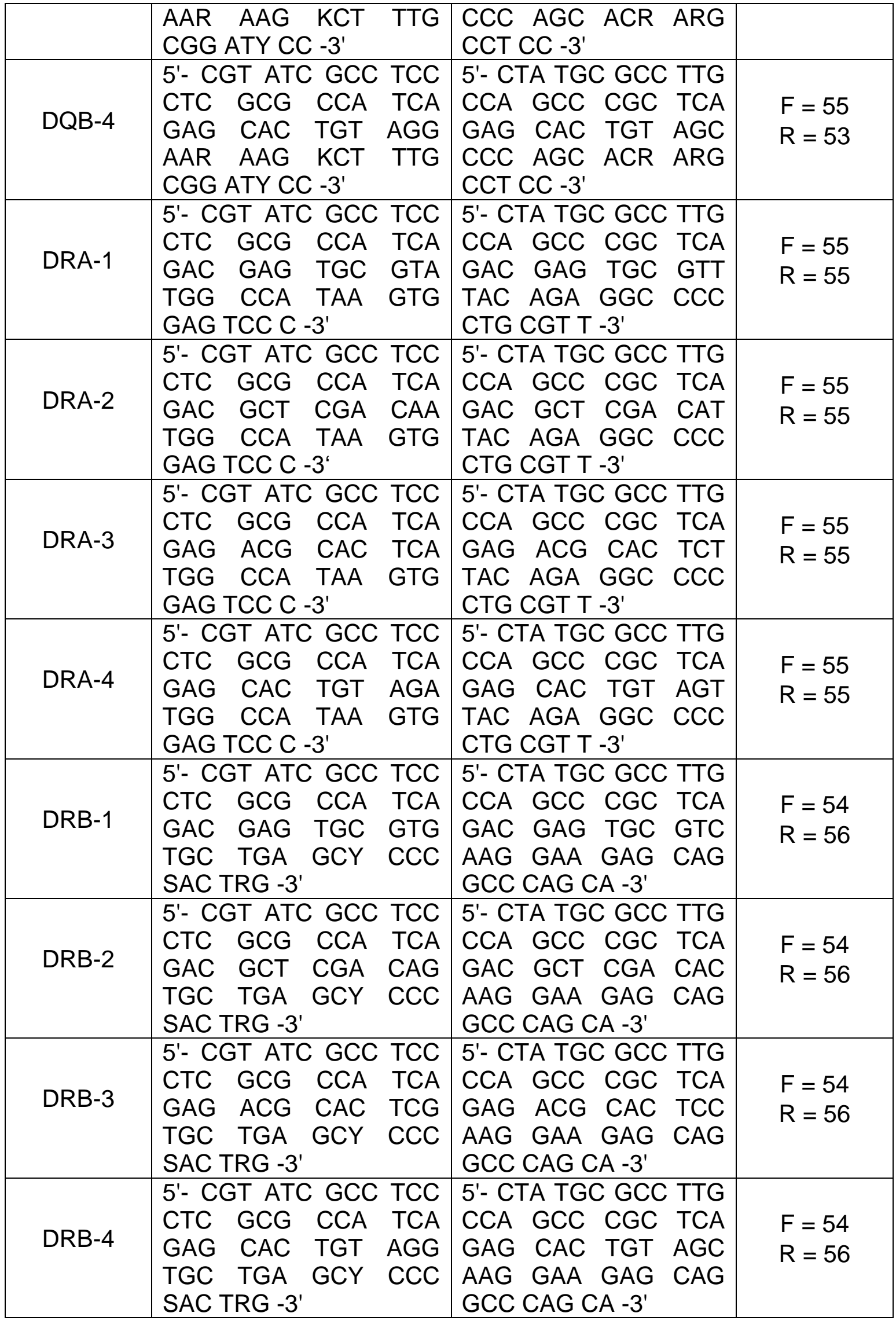


Table 8A: Oligonucleotide sequences for Rhesus MHC class II PCR amplification

\begin{tabular}{|c|c|c|c|}
\hline Cycle Step & Temperature & Time & Cycles \\
\hline Initial Denaturation & $95^{\circ} \mathrm{C}$ & 5 minutes & \\
\hline Denaturation & $95^{\circ} \mathrm{C}$ & 30 seconds & \multirow{2}{*}{$35 \times$} \\
\cline { 1 - 3 } Annealing & $55^{\circ} \mathrm{C}$ & 30 seconds & \\
\cline { 1 - 3 } Extension & $72^{\circ} \mathrm{C}$ & 60 seconds & \multirow{2}{*}{$1 \mathrm{X}$} \\
\hline Final extension & $72^{\circ} \mathrm{C}$ & 7 minutes & \\
\hline
\end{tabular}

Table 8B: Amplification program for MHC Class II

\subsection{Cardiomyocyte differentiation}

\subsubsection{Directed differentiation}

iPS cells were enzymatically dissociated with Tryple ${ }^{\mathrm{TM}}$ (section 2.3.4) and plated at a seeding density of 25,000 cells $/ \mathrm{cm}^{2}$ on Matrigel ${ }^{\mathrm{TM}}$ coated culture flasks (T25, Corning) for the Sendai RhiPS cells or encapsulated at a density of $2 \times 10^{6}$ in alginate for the Lenti RhIPS cells (section 2.4.2) with approximately 25 free floating beads per T25 culture flask, in mTeSR ${ }^{\text {TM }}$ E8 medium (E8, Stemcell Technologies) supplemented with $10 \mu \mathrm{mol} / \mathrm{L}$ Rock Inhibitor (RI; Y-27632); this starting time-point was recorded as differentiation day -4 . Exchange with fresh E8 Medium with $5 \mu \mathrm{mol} / \mathrm{L}$ RI was performed after 48 hours (differentiation day -2). After four days of recovery and cellular expansion, directed differentiation under defined medium supplements was started (differentiation day 0). To initiate the mesodermal stage of differentiation, E8 medium was replaced by SFBM (serum-free basal medium; Appendix A2) supplemented with small molecule growth factors ABCF: Activin-A (R\&D systems; $9 \mathrm{ng} / \mathrm{ml}$ ), BMP4 (R\&D

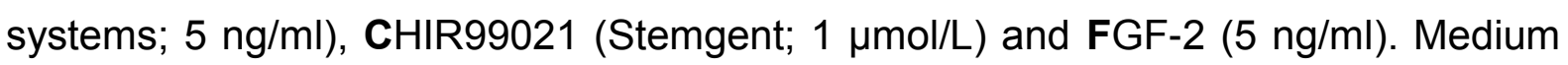
was exchanged daily until day 3 , at which point the cardiac specification stage was induced for the next 10 days. Small molecules ABCF were replaced in the SFBM medium by the addition of an inhibitor of Wnt production (IWP4; Stemgent; 5 $\mu \mathrm{mol} / \mathrm{L})$. Fresh medium was exchanged every 2-3 days until day 13 . On day 14 the 
differentiated cardiomyocytes underwent lactate selection, SFBM was replaced by a lactate selection medium (RPMI without glucose, $100 \mathrm{U} / \mathrm{ml}$ Penicillin, $100 \mu \mathrm{g} / \mathrm{ml}$ Streptomycin, $2.2 \mathrm{mmol} / \mathrm{L}$ sodium lactate and $0.1 \mathrm{mmol} / \mathrm{L} \mathrm{2-mercaptoethanol)} \mathrm{and}$ changed daily for 4-7 days dependent upon visual inspection for loss of nonmyocytes. Following lactate selection cardiomyocyte cultures were returned to SFBM medium until differentiation day 28 when EHMs were generated (refer to section 2.5.2).

\subsubsection{Alginate encapsulation}

Undifferentiated Lenti-iPS cells were passaged with Tryple ${ }^{\mathrm{TM}}$ (section 2.3.4), counted using a CASY counter (section 2.6.1), and manually encapsulated in an alginate hydrogel. Briefly, a $1 \%$ alginate-gelatin encapsulation solution was prepared by mixing alginic acid sodium salt (MP Biomedicals) with $0.1 \%$ gelatin overnight at RT on an orbital shaker (Certomat ${ }^{\circledR}$ R; B. Braun) at 150 revolutions per minute. After the alginate salt dissolved completely in gelatin, $9 \% \mathrm{NaCl}$ was added to the alginate-gelatin mixture and vortexed thoroughly for 3 minutes. For encapsulation, previously dissociated stem cells $\left(2 \times 10^{6} / \mathrm{ml}\right)$ were centrifuged at $300 \mathrm{~g}$ for 5 minutes. Supernatant was removed from the pellet and $1 \%$ alginate-gelatin solution plus $10 \mu \mathrm{mol} / \mathrm{L} \mathrm{RI}$ was added to the pellet at a volume dependent on cell quantity. Cells and alginate were pipetted to ensure equal distribution of cells in suspension. Encapsulated beads were generated by pipetting $25 \mu \mathrm{l}$ of the cell:alginate suspension dropwise into a $\mathrm{CaCl}_{2}$ solution $(50 \mathrm{mmol} / \mathrm{L})$ in a swirled $50 \mathrm{ml} \mathrm{PP}$ tube. Beads stayed in the bath for five minutes. The contents of the PP tube were then decanted through a $70 \mu \mathrm{m}$ cell strainer (BD Biosciences) to separate the alginate beads from the $\mathrm{CaCl}_{2}$. Beads were washed three times by dispensing $5 \mathrm{ml}$ of $\mathrm{CaCl}_{2}$ over the beads in the filter. The beads were then transferred into culture flasks (25 beads/T25; adapted from Sidhu et al. 2012). Beads were cultured according to section 2.4.1.

\subsection{EHM Generation}

\subsubsection{Construction of EHM casting molds and dynamic stretchers}

For the generation of EHM, circular molds (diameter: $10 \mathrm{~mm}$ ) with a central silicone pole (diameter: $2 \mathrm{~mm}$, length: $10 \mathrm{~mm}$ ) were fabricated using a silicone mixture (Sylgard $^{\circledR} 185$ silicone mixture) in a multistep process (Figure 8A). Hollow silicone tubing 
(diameter: $4 \mathrm{~mm}$ ) was placed over the central poles of each mold to create a removable spacer in which the EHM condenses around. A more detailed protocol for the preparation of the casting molds was previously published (Soong et al. 2012, Tiburcy et al. 2014). Additionally, flexible silicone stretchers (length: $5 \mathrm{~mm}$, thickness: $1.5 \mathrm{~mm}$, inner/outer distance: $3 / 6 \mathrm{~mm}$ ) with a circular silicone base (diameter: 12 $\mathrm{mm}$, thickness: $2 \mathrm{~mm}$ ) were fabricated for facilitation of auxotonic contractions of EHM (Fig. 8B). The fully assembled casting molds and the flexible stretchers can be autoclaved and reused.
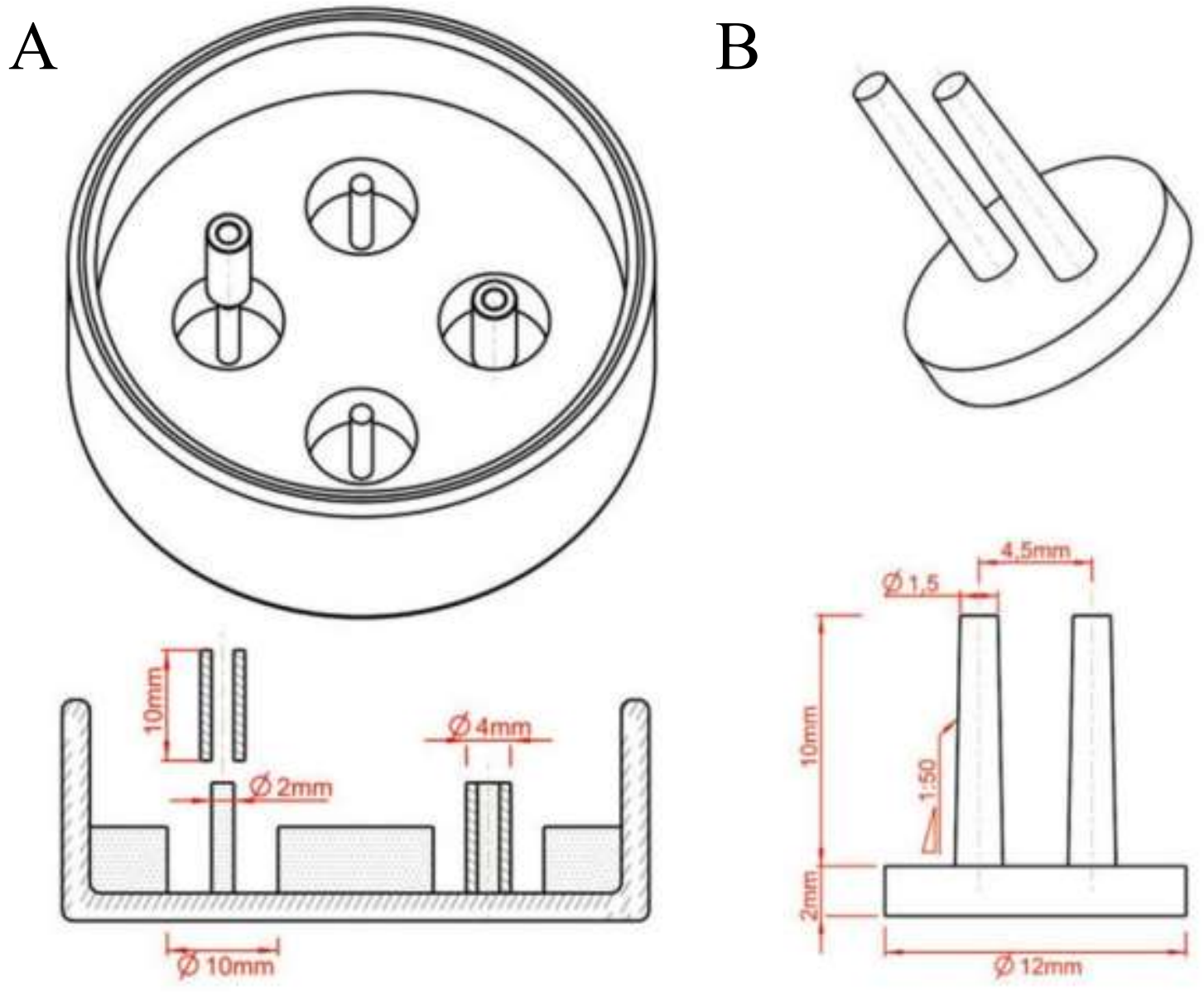

\section{Figure 8: Reusable EHM mold and stretcher}

Reusable silicone casting molds with silicone poles for EHM generation and elastic stretchers for mechanical loading and EHM maturation. (A) Glass culture dish filled with transparent silicone creating 4 circular recesses (diameter: $10 \mathrm{~mm}$ ) with central poles (diameter: $2 \mathrm{~mm}$, length: $10 \mathrm{~mm}$ ). Each central pole has silicone tubing (outer diameter: $4 \mathrm{~mm}$ ) placed over it to provide an inner diameter of $4 \mathrm{~mm}$ during $\mathrm{EHM}$ 
generation. (B) Dynamic silicone poles (length: $10 \mathrm{~mm}$, thickness: $1.5 \mathrm{~mm}$, inner/outer distance: $3 / 6 \mathrm{~mm}$ ) with silicone base (diameter: $12 \mathrm{~mm}$, thickness: $2 \mathrm{~mm}$ ). Images modified from Tiburcy et al., 2014.

\subsubsection{Casting of EHM}

A master mix for EHM (Table 9) generation was made by combining ice cold type I bovine collagen (0.4 mg/EHM), 2x RPMI, and $\mathrm{pH}$ neutralized with $\mathrm{NaOH}(0.1 \mathrm{~mol} / \mathrm{L})$ in a prechilled $50 \mathrm{ml} \mathrm{PP}$ tube (Table 9). Cardiomyocytes in single cell suspension $\left(1.015 \times 10^{6} / \mathrm{EHM}\right)$ and primary fibroblasts $\left(0.435 \times 10^{6} / \mathrm{EHM}\right)$ were combined in appropriate quantities depending on the desired number of EHMs in a $15 \mathrm{ml}$ PP tube and centrifuged at $300 \mathrm{~g}$ for 5 minutes. Supernatant was removed from the pellet and the pellet was resuspended in the appropriate volume of pre-warmed Serum Free Maturation Medium (SFMM; Appendix A4) according to Table 9 making a cardiomyocyte:fibroblast cell suspension. The cell suspension was combined with the EHM master mix and gently pipetted until cells were equally distributed through the master mix, ensuring that no bubbles were formed. $450 \mu \mathrm{l}$ of the resulting EHM mixture was gently pipetted into individual circular recesses of the casting molds (Figure $8 \mathrm{~A}$ ) and placed in a $37{ }^{\circ} \mathrm{C}$ humidified incubator with $5 \% \mathrm{CO}_{2}$ for 1 hour. Following solidification of the collagen matrix, $6 \mathrm{ml}$ of pre-warmed SFMM with TGF $\beta-1$ (1 $\mathrm{ng} / \mathrm{ml}$ ) was added to the dishes ensuring complete coverage of each EHM with medium. Fresh SFMM with TGF $\beta-1(1 \mathrm{ng} / \mathrm{ml})$ was exchanged at 24 and 72 hours after casting.

\begin{tabular}{|l||l|l|}
\hline Number of EHM & $4 x$ & $8 x$ \\
\hline $\begin{array}{l}\text { Bovine Collagen Type I }(6.6 \\
\mathrm{mg} / \mathrm{ml})\end{array}$ & $283 \mu \mathrm{l}$ & $566 \mu \mathrm{l}$ \\
\hline $2 \mathrm{X}$ DMEM & $283 \mu \mathrm{l}$ & $566 \mu \mathrm{l}$ \\
\hline $\mathrm{NaOH} 0.1 \mathrm{~mol} / \mathrm{L}$ & $56 \mu \mathrm{l}$ & $112 \mu \mathrm{l}$ \\
\hline Cell Suspension & $1,479 \mu \mathrm{l}$ & $2,958 \mu \mathrm{l}$ \\
\hline
\end{tabular}




\begin{tabular}{|l||l|l|}
\hline$\left(1.45 \times 10^{6}\right.$ cells/EHM $)$ & & \\
\hline TOTAL VOLUME & $2,106 \mu \mathrm{l}$ & $4,212 \mu \mathrm{l}$ \\
\hline
\end{tabular}

Table 9: EHM reconstitution mixture

\subsubsection{Culturing of EHM}

Freshly cast EHMs were incubated in SFMM with TGF $-1(5 \mathrm{ng} / \mathrm{ml})$ for the first 3 days of culture in which the EHMs progressively condensed. On culture day 31 EHMs were transferred onto dynamic silicon stretchers (Figure 9A). First, autoclaved stretchers were placed into a tissue culture plate filled with SFMM. Next, to transfer the EHMs from the casting mold onto stretchers the removable silicone tubing was gently removed from the stationary central support pole with a pair of curved forceps. The poles of the stretchers were pinched together with a second set of forceps and the silicon tube was placed over the poles of the stretcher and the EHM was gentle slid off the silicone tube onto the stretcher poles with a pipette tip. The contracting EHM will bend the silicone poles inducing dynamic load for the EHM to work against. Medium was exchanged every other day over the next 25 days of EHM maturation. EHMs were ready for end-point analyses after 28 days in EHM culture (Figure 9B).

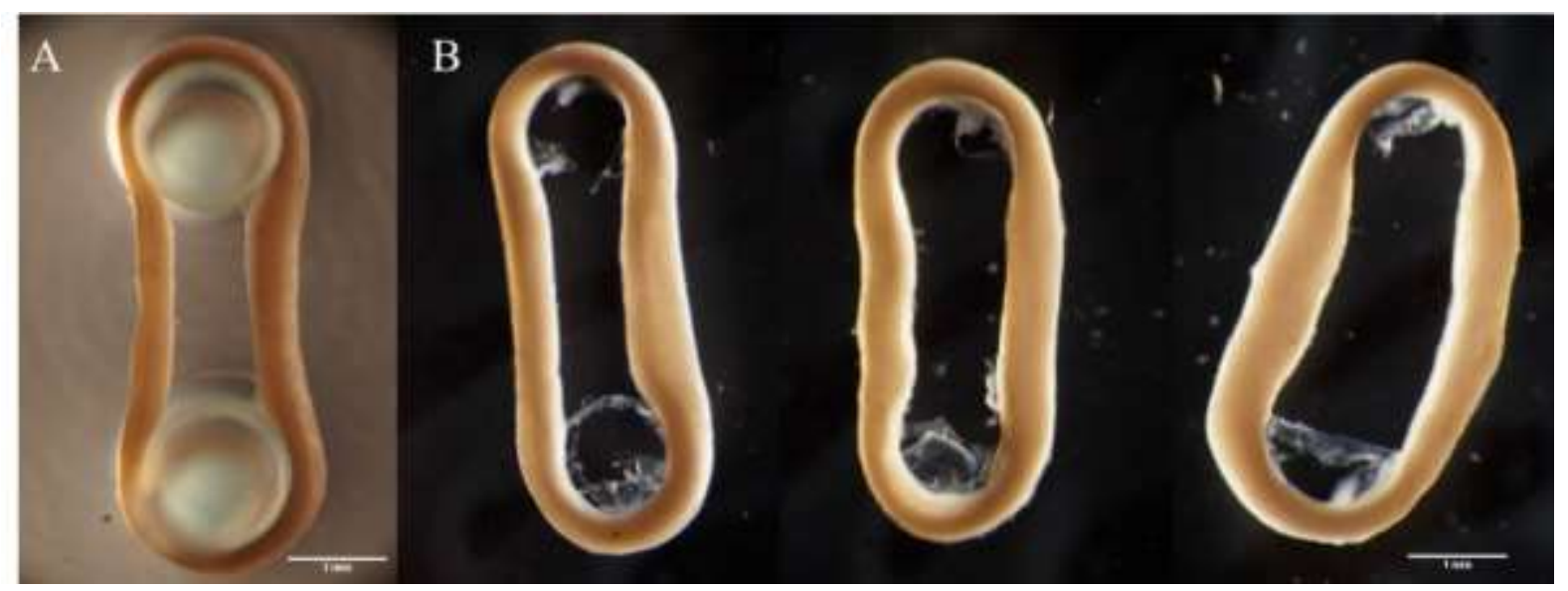

Figure 9: Rhesus iPS EHM 
After casting of EHMs they are placed on auxotonic silicon stretchers (A). Prior to isometric force measurements EHM are removed from the stretchers and inspected for integrity and spontaneous beating frequency (B). Scale bar: $1 \mathrm{~mm}$

\subsubsection{Dissociation of EHM}

Following isometric measurement of EHM functionality they were enzymatically dissociated for FACS analysis. To do so, collagenase (Sigma, $0.2 \%$ ) was prepared in PBS (with Calcium/Magnesium) with 20\% FBS and added to each EHM in a 12 well plate $\left(1 \mathrm{ml} /\right.$ well/EHM) and incubated for $60-90$ minutes at $37{ }^{\circ} \mathrm{C}$. After incubation, supernatant from each well was collected in individual PP tubes $(15 \mathrm{ml})$. An Accutase ${ }^{\circledR}$ solution (Millipore) supplemented with $0.025 \%$ Trypsin (2.5\%, Gibco) and 2\% DNase I (Lab stock at $1 \mathrm{mg} / \mathrm{ml}$, Calbiochem; Appendix A1) was added to each well $(1 \mathrm{ml} /$ well) to digest any remaining large pieces of EHM and incubated for an additional 30 minutes at room temperature. To stop Accutase $®$ digestion, 5\% FBS in PBS (without Calcium/Magnesium; $1 \mathrm{ml} /$ well) was added and gently pipetted 2-3 times. All contents of each well were transferred to the corresponding PP tube containing the collagenase supernatant. The contents of each PP tube were then filtered with a $40 \mu \mathrm{m}$ cell strainer cell strainer to remove any undigested clumps and leave a single cell suspension. Single cell suspensions obtained from the digested EHM were fixed in ethanol ( $70 \%$ Lab stock) for staining of intracellular markers via flow cytometry.

\subsection{Measurements and imaging}

\subsubsection{Cell count and size measurements}

Cell number, size and viability measurements from single cell suspensions were assessed using a CASY Model TT cell counter (Roche), according to the manufacturer's instructions. A Neubauer cell counting chamber was used to determine the number of total viable single cells after enzymatic dissociation.

\subsubsection{Isometric contraction measurements}

EHM force measurements were performed in temperature and $\mathrm{pH}$ regulated organ baths (FMI GMbH) as previously described (Soong et al. 2012, Zimmermann et al. 2000, Zimmermann et al. 2002). Briefly, following 25 days of dynamic loading on sili- 
con stretchers, EHMs were suspended between a retaining hook and force transducer in organ baths containing $0.2 \mathrm{mmol} / \mathrm{L}\left[\mathrm{Ca}^{2+}\right]$ Tyrode's solution (Figure 10; Table 10). Temperature within the organ bath was maintained at $37^{\circ} \mathrm{C}$ with an adjusted $\mathrm{pH}$ of 7.4 maintained by a constant flow of carbogen $\left(95 \% \mathrm{O}_{2}, 5 \% \mathrm{CO}_{2}\right.$ gas mixture). Calcium concentration of Tyrode's solution was adjusted to $1.8 \mathrm{mmol} / \mathrm{L}$ using a $\mathrm{CaCl}_{2}$ solution $(0.2 \mathrm{~mol} / \mathrm{L})$ diluted from stock solution $(2.25 \mathrm{~mol} / \mathrm{L})$. EHMs were equilibrated before an electrical field stimulus of $1.5 \mathrm{~Hz}$ was applied with monophasic pulse duration of $5 \mathrm{~ms}$ and an electrical current of $200 \mathrm{~mA}$. A stepwise preload strain was applied to the EHMs under an extracellular calcium concentration of $1.8 \mathrm{mmol} / \mathrm{L}$ until a length of maximal force development (Lmax) was reached in accordance with the Frank-Starling mechanism. Following the preload stretching, $0.2 \mathrm{mmol} / \mathrm{L}\left[\mathrm{Ca}^{2+}\right]$ Tyrode's solution was exchanged and EHMs were equilibrated before force measurements were obtained. Contractile force measurements were acquired using PCbased acquisition software (BMON, Engineering firm G. Jaeckel, Hanau) under cumulatively increasing $\left[\mathrm{Ca}^{2+}\right](0.2-4.0 \mathrm{mmol} / \mathrm{L})$. Force of contraction measurements, defined as the difference between maximum (peak systolic force) and minimum (diastolic) forces, were calculated from measurements taken at the steady state, approximately five minutes following addition of calcium. Analysis was performed using PC-based analysis software (AMON, Engineering firm G. Jaeckel, Hanau and Graph Pad Prism). Additional isoprenaline response and force frequency data were collected under half maximum effective concentration $\left(E_{50}\right)$ for extracellular calcium (Figures 17 and 18).

Stock I

\begin{tabular}{|l|l|}
\hline Tyrode $\left[\mathrm{Ca}^{2+}\right]$ & $0.2 \mathrm{mmol} / \mathrm{L}$ \\
\hline $\mathrm{NaCl}(\mathrm{MW}=58.44)$ & $175 \mathrm{~g}$ \\
\hline $\mathrm{KCl}(\mathrm{MW}=74.56)$ & $10 \mathrm{~g}$ \\
\hline $\mathrm{CaCl}_{2}$ stock $(2.25 \mathrm{M})$ & $2.22 \mathrm{ml}$ \\
\hline $\mathrm{MgCl}_{2}$ stock $(1.05 \mathrm{M})$ & $25 \mathrm{ml}$ \\
\hline adjusted with dd ${ }_{2} \mathrm{O}$ & $1000 \mathrm{ml}$ \\
\hline
\end{tabular}


Stock II

\begin{tabular}{|c|c|}
\hline $\mathrm{NaHCO}_{3}(\mathrm{MW}=84.01)$ & $50 \mathrm{~g}$ \\
\hline adjusted with $\mathrm{ddH}_{2} \mathrm{O}$ & $1000 \mathrm{ml}$ \\
\hline
\end{tabular}

Stock III

\begin{tabular}{|c|c|c|}
\hline $\mathrm{NaH}_{2} \mathrm{PO}_{4}(\mathrm{MW}=137.99)$ & $5.8 \mathrm{~g}$ & \\
\hline adjusted with $\mathrm{dd}_{2} \mathrm{O}$ & $1000 \mathrm{ml}$ & $\begin{array}{l}{ }^{*} A l l \text { stock solutions can be stored at } 4{ }^{\circ} \mathrm{C} \text { until } \\
\text { required. }\end{array}$ \\
\hline
\end{tabular}

Tyrode's Working Solution

\begin{tabular}{|l|l|l|l|l|}
\hline Stock I & $40 \mathrm{ml}$ & $80 \mathrm{ml}$ & $120 \mathrm{ml}$ & $200 \mathrm{ml}$ \\
\hline Stock II & $38 \mathrm{ml}$ & $76 \mathrm{ml}$ & $114 \mathrm{ml}$ & $140 \mathrm{ml}$ \\
\hline Stock III & $10 \mathrm{ml}$ & $20 \mathrm{ml}$ & $30 \mathrm{ml}$ & $50 \mathrm{ml}$ \\
\hline Glucose & $1 \mathrm{~g}$ & $2 \mathrm{~g}$ & $3 \mathrm{~g}$ & $5 \mathrm{~g}$ \\
\hline Ascorbic Acid & $100 \mathrm{mg}$ & $200 \mathrm{mg}$ & $300 \mathrm{mg}$ & $500 \mathrm{mg}$ \\
\hline Adjusted with ddH $\mathrm{H}_{2} \mathrm{O}$ & $1000 \mathrm{ml}$ & $2000 \mathrm{ml}$ & $3000 \mathrm{ml}$ & $5000 \mathrm{ml}$ \\
\hline
\end{tabular}

Table 10: Tyrode's solutions for isometric force measurements.

*All constituents were combined in a volumetric flask and thoroughly mixed before use. Working solution should be made fresh no more than 24 hours prior to isometric force measurement. 


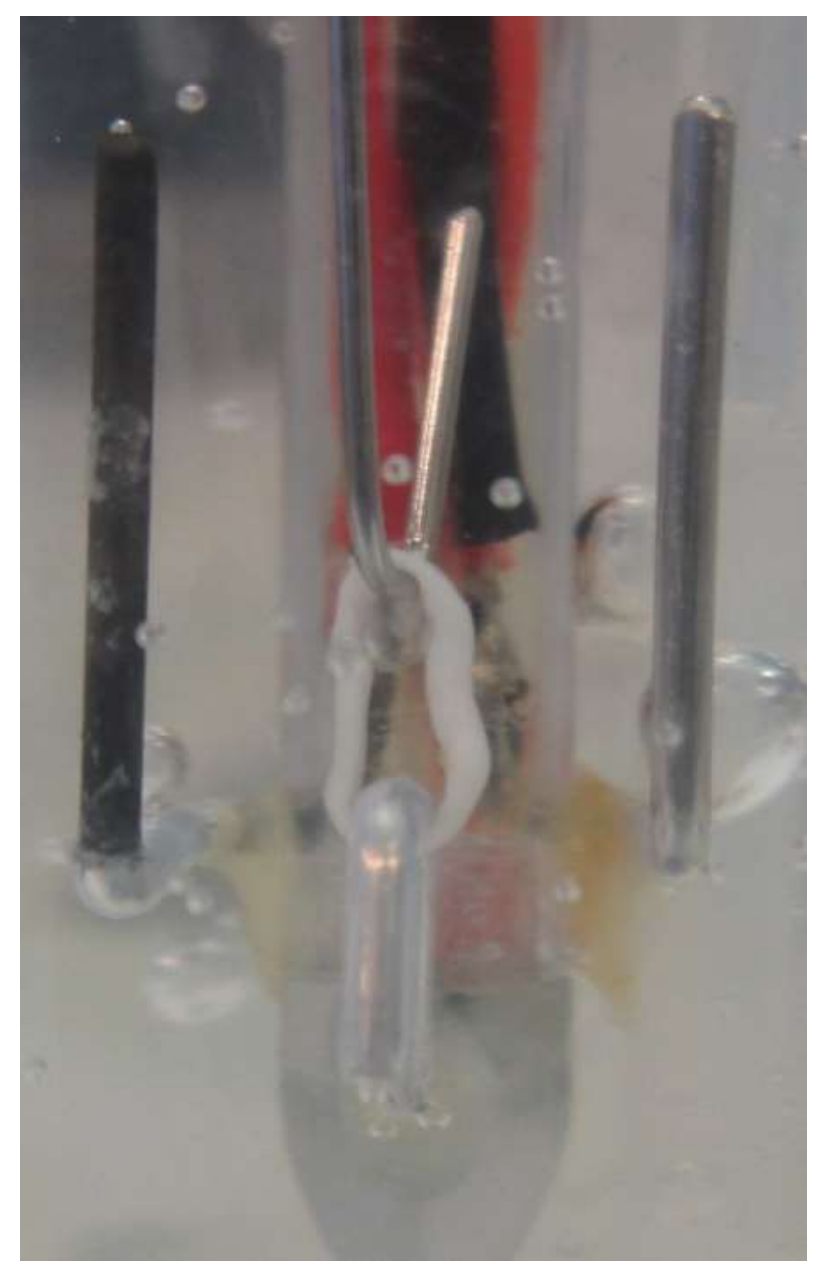

\section{Figure 10: EHM in organ bath}

Isometric force measurements were performed on EHMs suspended between two hooks attached to a force transducer in an insulated organ bath. Organ bath temperature was maintained at $37^{\circ} \mathrm{C}$ with an adjusted $\mathrm{pH}$ of 7.4 maintained by a constant flow of carbogen $\left(95 \% \mathrm{O}_{2}, 5 \% \mathrm{CO}_{2}\right.$ gas mixture). EHMs were subjected to cumulatively increasing extracellular calcium concentrations (0.2-4.0), isoprenaline (at $\mathrm{EC}_{50}$ $\left[\mathrm{Ca}^{2+}\right]$, pacing frequencies of $1-4 \mathrm{Hertz}$ in $0.5 \mathrm{~Hz}$ increments at $0.8 \mathrm{mmol} / \mathrm{L}\left[\mathrm{Ca}^{2+}\right]$, were applied with monophasic pulse duration of $5 \mathrm{~ms}$ and electric current of $200 \mathrm{~mA}$.

\subsubsection{Flow cytometry}

Assessment of cardiomyocyte purity prior to EHM construction and following isometric force measurements were performed using flow cytometry with a LSRII cytometer (BD). For data analysis FACSDiva Software 6.0 (BD) was applied. Cell suspensions fixed in $70 \% \mathrm{EtOH}$ and filtered through a $70 \mu \mathrm{m}$ cell strainer (BD Biosciences) were 
pelleted via centrifugation and permeabilized in blocking buffer (Appendix A5) for 10 minutes at $4{ }^{\circ} \mathrm{C}$. Samples were incubated for 45 minutes at $4{ }^{\circ} \mathrm{C}$ with a primary antibody against $\alpha$-sarcomeric actinin (1:1,000; Sigma-Aldrich; Appendix A6) followed by incubation with a goat anti-mouse Alexa 488 secondary antibody in blocking buffer (Invitrogen, A-11001; 1:1,000; Appendix A6) and Hoechst 33342 for 30 minutes at 4 ${ }^{\circ} \mathrm{C}$. A mouse immunoglobulin $\mathrm{G}(\mathrm{lgG})$ isotype control (R\&D systems) was used as negative control for non-specific staining. Cells were washed $(2 x)$ with blocking buffer and resuspended in PBS (without Calcium and Magnesium) for analysis with a BD LSRII (BS Biosystems). Samples were first gated (G1) based on Hoechst 33342 staining of viable cells followed by a secondary gating (G2) to isolate single cell population. Cardiomyocyte purity was based on a-actinin positive staining cells with an IgG isotype control used to determine non-specific staining (Figure 11). Analysis of samples was performed using Flowing Software 2.5.1.

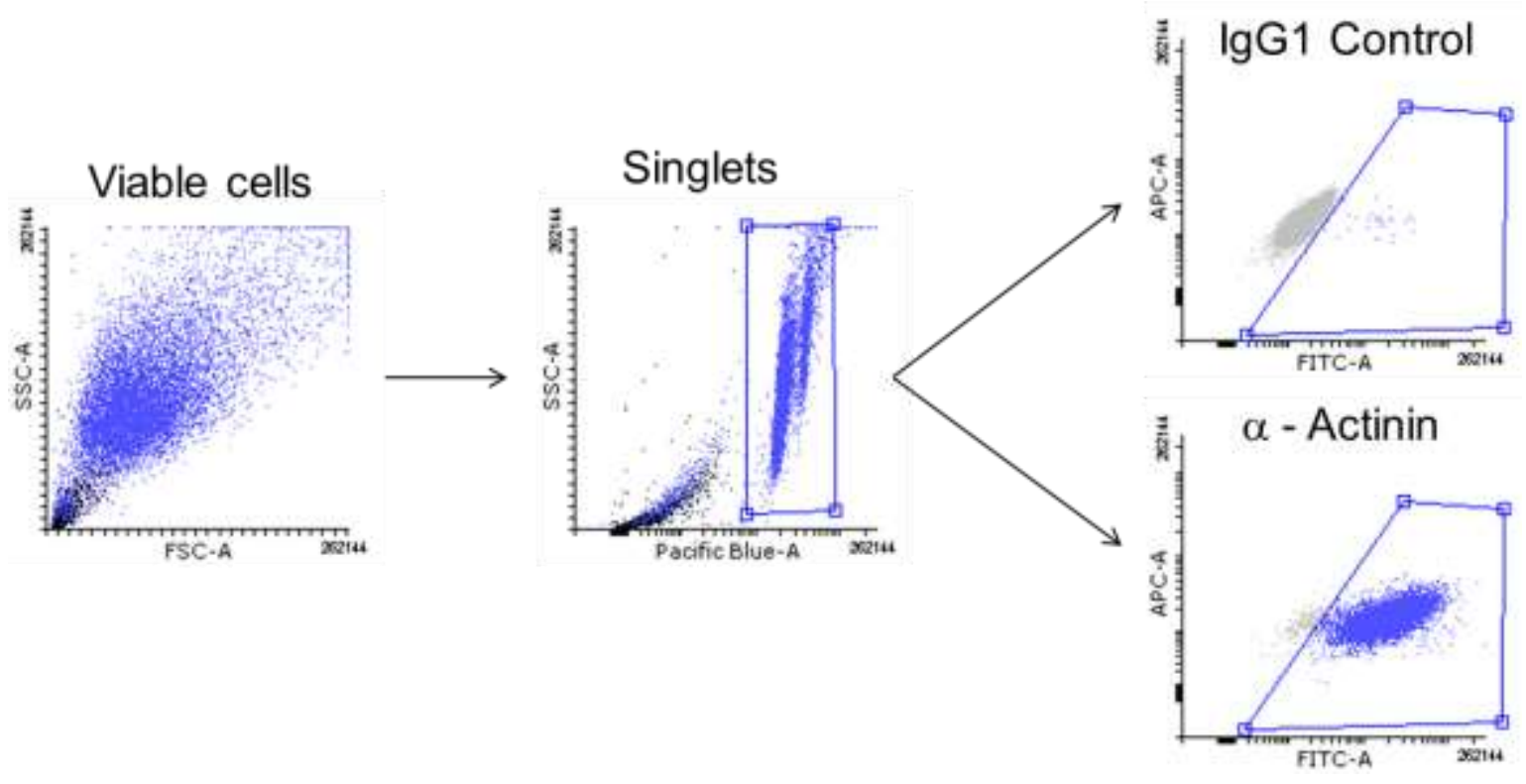

Figure 11: Gating strategy for a-actinin positive cardiomyocytes.

Viable cells were selected based on Hoechst 33342 intensity. Doublets were excluded based on side scatter area (SSC-A). Cardiomyocytes were distinguished based on a-actinin positivity. An IgG1 isotype control was used for exclusion of non-specific staining. 


\subsubsection{Immunofluorescence imaging}

Sample aliquots of differentiated cardiomyocytes were seeded onto Matrigel ${ }^{\mathrm{TM}}$ coated coverslips (1:120) in hES medium and incubated at $37^{\circ} \mathrm{C}$ for $4-7$ days to ensure cell attachment and recovery. When cells began spontaneous contractions via visual inspection coverslips were washed with PBS and fixed with 4\% Histofix for 10 minutes at room temperature. After another washing step with PBS, cells were permeabilized by incubation with blocking buffer (Appendix A5) for 30 minutes at RT. Primary antibody (Appendix A6) incubation directed against $\alpha$-sarcomeric actinin (Sigma-Aldrich), connexin 43 (BD Biosciences), T-box transcription factor 5 (Tbx-5; Sigma-Aldrich), myosin light chain 2a (MLC2a; atrial isoform; Synaptic Systems), and myosin light chain 2v (MLC2v; ventricular isoform; Synaptic Systems) was performed at RT for 60 minutes. Following primary antibody incubation coverslips were gently washed with PBS and incubated with secondary antibodies conjugated with fluorescent dyes (anti-mouse Alexa Fluor® 546, anti-rabbit Alexa Fluor® 488, antimouse Alexa Fluor $\AA$ 633; Molecular Probes ${ }^{\circledR}$ Appendix A6) and nuclei counterstained with Hoechst $33342(1: 1,000)$ at RT for 60 minutes. Samples were washed thoroughly with blocking buffer 3 times for 5 minutes with a final wash with only PBS for 5 minutes. Coverslips were mounted to superfrost microscopy slides with Fluoromount-G (Southern Biotech). The slides were air dried and stored in the dark until imaging was performed. Fluorescent images were obtained using a laser scanning confocal microscope (LSM710, Zeiss, Germany).

\subsubsection{Whole mount imaging}

Whole mount immunofluorescence imaging was performed to visualize cardiac muscle formation within EHMs. After cultivation, EHMs were washed once on 1X PBS and fixed in Roti® Histofix $4 \%$ overnight at $4{ }^{\circ} \mathrm{C}$. Thereafter, EHMs were washed once in $1 \mathrm{X}$ PBS and incubated in a permeabilizing blocking buffer solution for 24 hours at $4{ }^{\circ} \mathrm{C}$. EHMs were subsequently incubated with primary antibodies (Appen$\operatorname{dix}$ A6) targeting $\alpha$-actinin $(1: 1,000)$ and connexin $43(1: 1,000 ;)$ for 48 hours on a rotary microfuge holder at $4{ }^{\circ} \mathrm{C}$. EHMs were then washed in blocking buffer (Appendix A5) for 24 hours on a rotary microfuge holder at $4{ }^{\circ} \mathrm{C}$, followed by the incubation with the goat anti-mouse Alexa 488 secondary antibody (1:400; Appendix A6), a goat anti-rabbit Alexa 633 secondary antibody (1:400; Appendix A6) and a F-actin labelling dye, phalloidin (conjugated with Alexa Fluor ${ }^{\circledR}$ 546, 1:60; Appendix A6) and the 
nuclei labelling dye, Hoechst 33342 for a further 48 hours on a rotary microfuge holder at $4{ }^{\circ} \mathrm{C}$ in the dark. EHMs were again thoroughly washed in blocking buffer (Appendix A5) for 24 hours and were immediately mounted onto superfrost microscopy slides with Fluoromount-G mounting medium (Southern Biotech) and stored in the dark until microscopic analysis was performed. Whole mount images were obtained using a Zeiss LSM710 confocal microscope.

\subsection{Statistical analysis}

Data were analyzed using Graph Pad Prism 7 software (Graph Pad Software Inc, San Diego) and displayed as mean \pm standard error of the mean (SEM). $n$ indicates the number of samples. Statistical analyses used were unpaired, two-sided Student's t-test and one-way ANOVA followed by an appropriate post hoc test as indicated in the results section. A $P<0.05$ was set to determine significant differences. 


\section{Results}

The macaque model has been suggested as clinically predictive for investigating stem cell based therapeutics for the treatment of post myocardial infarction heart failure (Bel et al. 2010, Blin et al. 2010, Shiba et al. 2016). The primary aim of this research was to validate the ability of Rhesus macaque iPS cells to be directly differentiated into cardiomyocytes for use in generating functional EHMs. Two variants, a lentiviral and a Sendai viral transduced line of RhiPS cells, were utilized for cardiomyocyte differentiation and EHM construction.

\subsection{Encapsulation of Lenti-iPS cells in an alginate:gelatin hydrogel}

Our current monolayer differentiation protocol established for human ES and iPS cells has a 4-day period in which stem cells are cultured on Matrigel ${ }^{\mathrm{TM}}$ coated plates in E8 medium with $10 \mu \mathrm{mol} / \mathrm{L} \mathrm{RI}$ prior to cardiac differentiation (Tiburcy et al. 2017). First attempts to direct the differentiation of the Lenti-iPS cell into cardiomyocytes using a previous version of this protocol that used a 50:50 hES:hFF conditioned medium rather than E8 medium did not yield reliable results. Thus, an alternative culturing strategy with alginate encapsulation to better control the cell growth milieu was investigated. It has been previously shown that encapsulation of stem cells in conjunction with culturing in fibroblast conditioned medium plus RI significantly enhances the viability of the cells (Sidhu et al. 2012). To investigate the effect of culturing and differentiating Lenti-iPS cells in alginate hydrogel beads, variable seeding densities and RI concentrations were tested. Four days prior to the start of directed differentiation, Lenti-iPS cells were dissociated from fibroblast feeder cultures and encapsulated in a 1\% alginate:-gelatin hyrdogel at seeding densities of $2 \times 106 \mathrm{cells} / \mathrm{ml}$, $1.5 \times 10^{6} \mathrm{cells} / \mathrm{ml}$, and $1.0 \times 10^{6} \mathrm{cell} / \mathrm{s} / \mathrm{ml}$ as described in section 2.4 .2 with either 5 $\mu \mathrm{mol} / \mathrm{L} \mathrm{Rl}$ or $10 \mu \mathrm{mol} / \mathrm{L}$ (Figure 12A). Encapsulation of Lenti-iPS cells in $25 \mu \mathrm{L}$ alginate resulted in beads with a $3 \pm 0.07 \mathrm{~mm}(\mathrm{n}=7)$ diameter (Figure 12B) and a reproducible growth volume of $15 \pm 1.2 \mu \mathrm{l}(\mathrm{n}=7)$ within the beads (Figure 12C-E). 


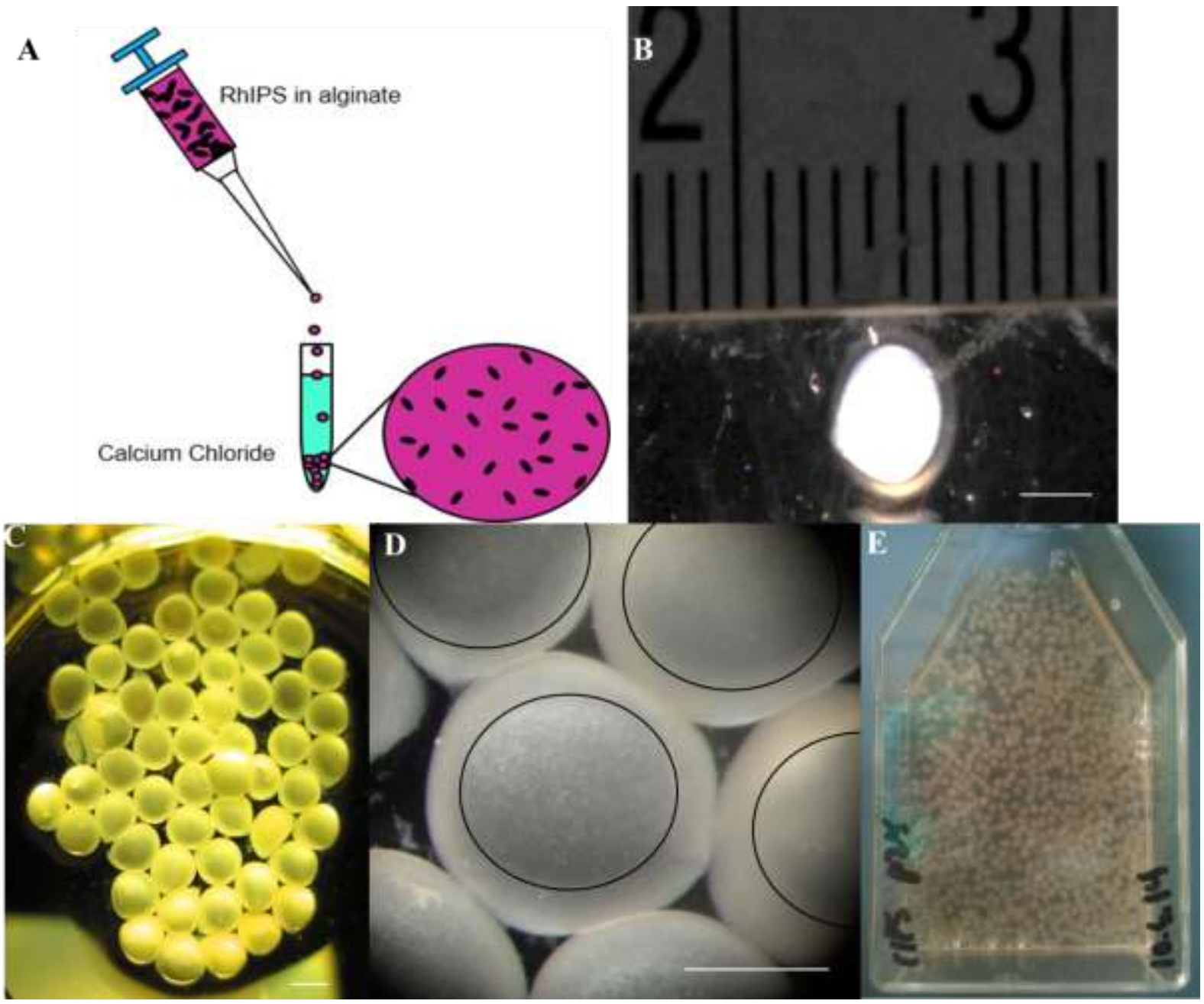

\section{Figure 12: Encapsulation of Lenti-iPS cells:}

A) Lenti-iPS cells were mixed with $1 \%$ alginate:gelatin and added dropwise $(25 \mu \mathrm{l})$ to a $50 \mathrm{mmol} / \mathrm{L} \mathrm{CaCl}_{2}$ bath in a $50 \mathrm{ml} \mathrm{PP}$ tube. Alginate was immediately crosslinked upon contact with calcium cations in the $\mathrm{CaCl}_{2}$. B) An alginate bead immediately after $25 \mu \mathrm{l}$ the alginate:cell suspension was dropped into $50 \mathrm{mmol} / \mathrm{L}$ of $\mathrm{CaCl}_{2} . \mathrm{C}$ ) Consistent size and shape of beads formed by dropwise generation. D) 40X magnification of encapsulated Lenti-iPS cells, black circles signify interface between liquefied center and crosslinked hydrogel shell, white dots within circles are encapsulated cells/aggregates. E) Over 600 alginate beads in a T175 flask, representing more than $30 \times 10^{6}$ RhIPS capable of differentiating into cardiomyocytes. Scale bars: 2 $\mathrm{mm}$

At time points of $24,48,72$, and 96 hours after encapsulation beads were removed 
from culture ( $\mathrm{n}=5$ beads/ time point; in triplicate), dissociated with an alginate dissociation solution (Appendix A9) and counted with a CASY counter to quantify the increase in cell number at each time point. Under treatment with $5 \mu \mathrm{mol} / \mathrm{L} \mathrm{RI}$ there was a significant increase in cell number after 72 hours in culture $(P<0.05$ vs. 0 hours post encapsulation) when cells were encapsulated at a concentration of $2 \times 10^{6}$ cells $/ \mathrm{ml}$ (Figure 13A). However, this increase in cell number decreased to below the starting number of cells encapsulated at the 96-hour time point in which differentiation begins under our standard protocol. Culturing of encapsulated cells with 10 $\mu \mathrm{mol} / \mathrm{L} \mathrm{RI}$ resulted in an overall increase in cell number within all three concentration groups at all time points tested. However, the increases in cell number were not significant when compared to the corresponding initial encapsulation concentrations (Figure 13B). Following successful encapsulation in alginate beads, we investigated the ability of Lenti-iPS cells to differentiate into cardiomyocytes.
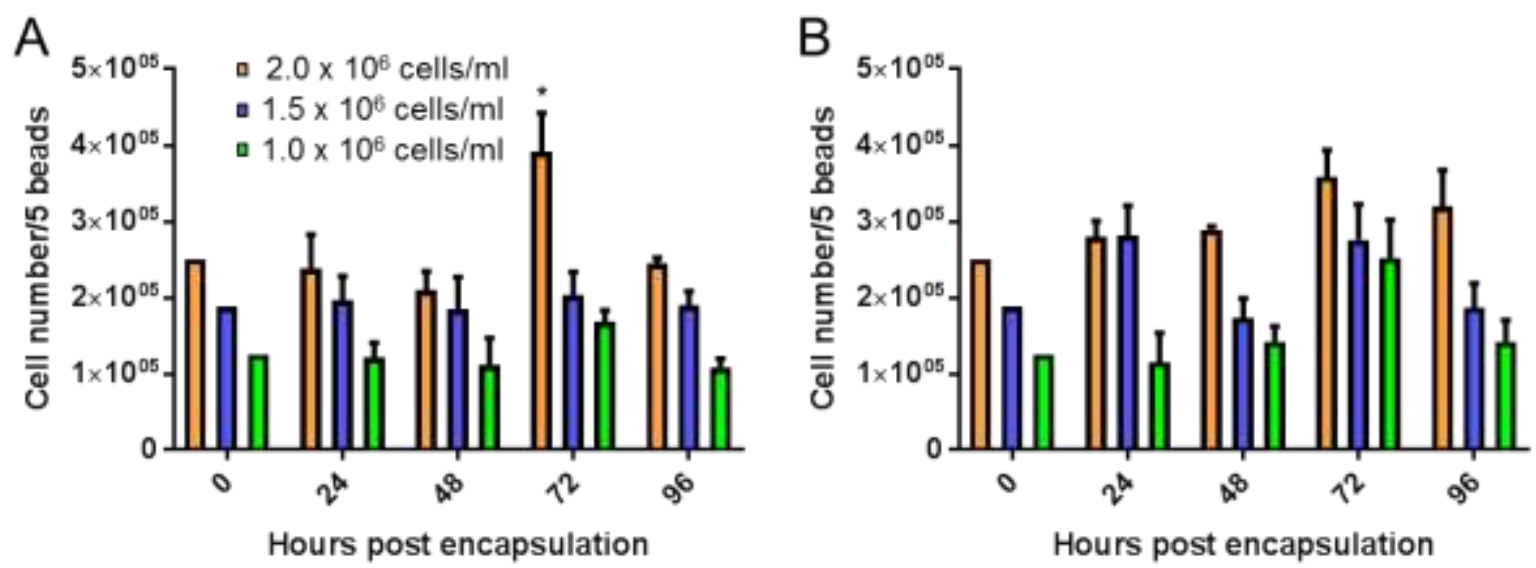

Figure 13: Increase in cell number following encapsulation.

Lenti-iPS cells were encapsulated at the indicated concentrations in alginate. Encapsulated cells were cultured for 96 hours in E8 medium with either $5 \mu \mathrm{mol} / \mathrm{L}(\mathrm{A})$ or 10 $\mu \mathrm{mol} / \mathrm{L}$ (B) ROCK inhibitor. Every 24 hours cell content per bead was analyzed. $n=5$ beads/time point, in triplicate; ${ }^{*} \mathrm{P}<0.05$ vs. 0 hours post encapsulation; 1 -way ANOVA for correlated samples with Tukey's HSD test.

\subsection{Directed differentiation of alginate encapsulated Rhesus Lenti-iPS cells in suspension culture}

Following alginate encapsulation, Lenti-iPS cells were cultured for 4-days in 50:50 
hES:hEF conditioned medium plus $10 \mu \mathrm{mol} / \mathrm{L} \mathrm{Rl}$ and $5 \mathrm{ng} / \mathrm{ml} \mathrm{FGF-2,} \mathrm{similar} \mathrm{to} \mathrm{our}$ standard E8 differentiation protocol (Tiburcy et al. 2017). Directed progression into the mesodermal lineage was induced during the first 3 days through incubation with a small molecule Wnt signaling activator CHIR99021 (1 $\mu \mathrm{mol} / \mathrm{L})$, and the growth factors FGF-2 $(5 \mathrm{ng} / \mathrm{ml})$, Activin-A $(9 \mathrm{ng} / \mathrm{ml})$ and BMP4 $(5 \mathrm{ng} / \mathrm{ml})$. Cardiac specification occurred over the next 10 days through the inhibition of the Wnt signaling pathway by incubation with IWP4 ( $5 \mu \mathrm{mol} / \mathrm{L})$. Cardiomyocyte selection and enrichment was preformed over the next 4-7 days through replacement of glucose with a lactate selection culture medium (Appendix A3). A post selection recovery period of 7-10 days was provided in which cells were cultured in standard SFBM + FGF-2 $(5 \mathrm{ng} / \mathrm{mL})$. On differentation day 28 cardiomyocytes were dissociated and counted. Successful differentiation of encapsulated Lenti-iPS cells resulted in an average cellular output of $253,776 \pm 36,055$ cells/cm2 $(n=5)$. This equals a difference of 203,776 $\pm 36,055$ cells $/ \mathrm{cm}^{2}$ or a $5.1 \pm 0.7$-fold increase over original seeding input of $50,000 \mathrm{cells} / \mathrm{cm} 2$. Next, cells were either with fixed and analyzed by flow cytometry (section 2.6.3) or combined with hFF cells for the generation of EHMs (section 2.5.2). Differentiated Lenti-iPS cell derived cardiomyocytes averaged a purity of $58 \pm 7 \%(n=5)$ based on flow cytometry analysis of $\alpha$-actinin positive staining (Figure 14).
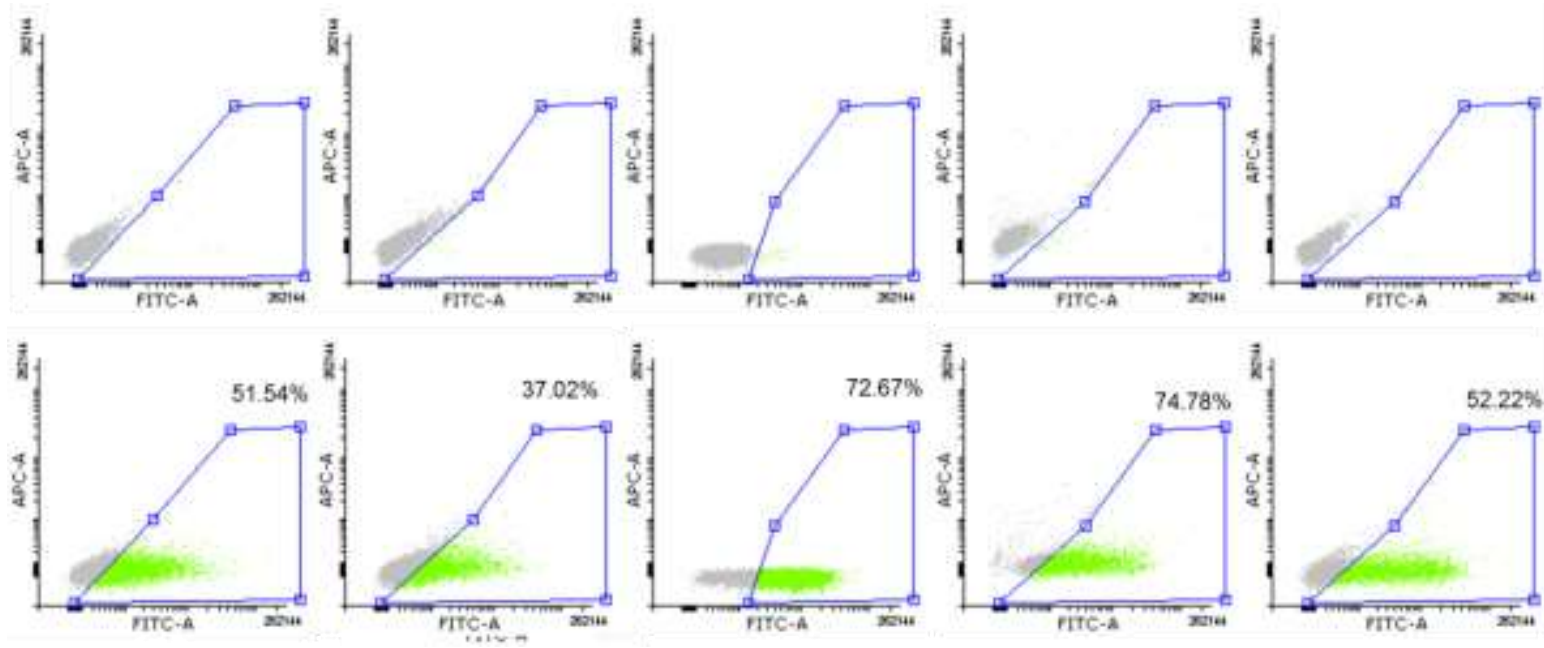

Figure 14: Cardiomyocyte purity following differentiation in alginate beads.

Prior to generation of EHMs, cardiomyocyte purity was assessed using FACS analysis. Cardiomyocytes were identified by a positive labelling for $\alpha$-actinin (bottom pan- 
els). Isotype controls were included (top panels) to enable gating of the cardiomyocyte fraction. Original recordings from 5 independent experiments.

\subsection{Directed differentiation of Rhesus Sendai iPS cells in monolayer culture}

At differentiation day -4 , undifferentiated Sendai iPS cells were plated in monolayers on Matrige ${ }^{\circledR}$ at an average seeding density of $7,696 \pm 1,328$ cells $/ \mathrm{cm}^{2}(n=18)$. A combination of variable culture flask areas $\left(25-175 \mathrm{~cm}^{2}\right)$ and variable seeding densities $\left(4,000-25,000\right.$ cells $\left./ \mathrm{cm}^{2}\right)$ were investigated to identify the optimal seeding density. The cardiomyocyte differentiation followed the same protocol as described above for the Lenti-iPS cells (Tiburcy et al. 2017). Mesodermal lineage was induced during the first 3 days through incubation with CHIR99021, FGF-2, Activin-A and BMP4. Cardiac specification occurred over the next 10 days through the inhibition of the Wnt-pathway with IWP4. Cardiomyocyte selection and enrichment was preformed over the next 4-7 days through replacement of glucose with a lactate selection medium. A post selection recovery period of 7-10 days was provided with culturing in standard SFBM + FGF-2 $(5 \mathrm{ng} / \mathrm{ml})$. On differentiation day 28 cardiomyocytes were dissociated and counted. Successful differentiation of monolayer Sendai iPS cells resulted in an average cellular output of $64,117 \pm 16,789 \mathrm{cells} / \mathrm{cm}^{2}(\mathrm{n}=8)$. This equals a difference of $54,945 \pm 14,635$ cells $/ \mathrm{cm}^{2}$ or a $7.5 \pm 1.7$-fold increase over an average original seeding input of $9,173 \pm 2,651$ cells $/ \mathrm{cm}^{2}(n=8)$. Cells were either with fixed and analyzed by flow cytometry or combined with Rhesus macaque gingival fibroblasts for the generation of EHMs. Differentiated Sendai cardiomyocytes averaged a purity of $91 \pm 3 \%(n=6)$ based on flow cytometry analysis of $\alpha$-actinin positive staining (Figure 15). 

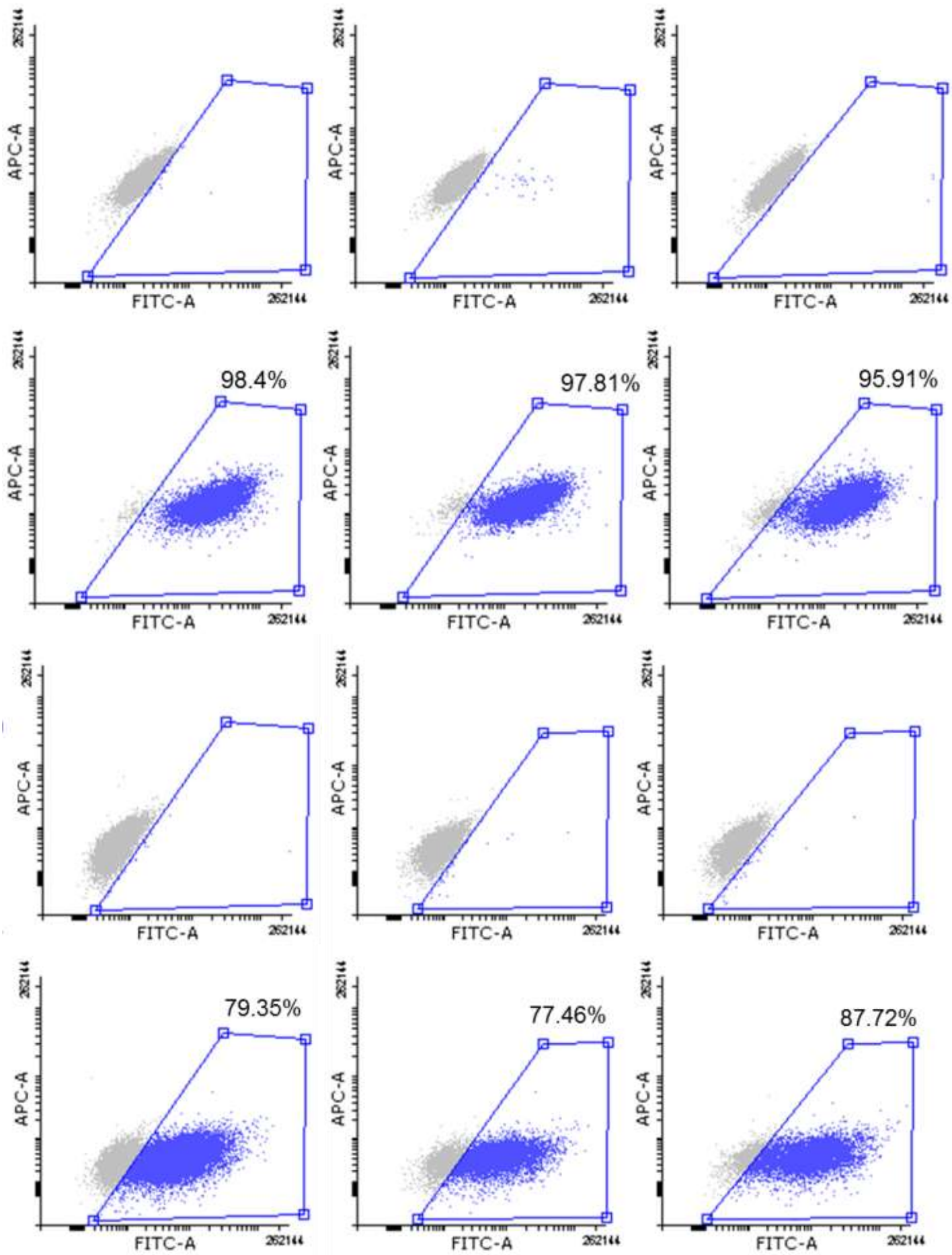

Figure 15: Cardiomyocyte purity following differentiation of Sendai iPS cells in monolayer culture.

Prior to generation of EHMs, cardiomyocyte purity was assessed using FACS analysis in differentiation culture. Cardiomyocytes were identified by a positive labelling for a-actinin (blue). Isotype controls were included (grey) to enable gating of the cardiomyocyte fraction. Original recordings from the 6 independent experiments. 
Fluorescence imaging analysis of Sendai-iPS-cell-derived cardiomyocytes after staining for $\alpha$-actinin staining and Tbx-5 demonstrated the presence of canonical cardiomyocyte markers. Additional staining for connexin 43 revealed the formation of gap junctions between cardiomyocytes (Figure 16).

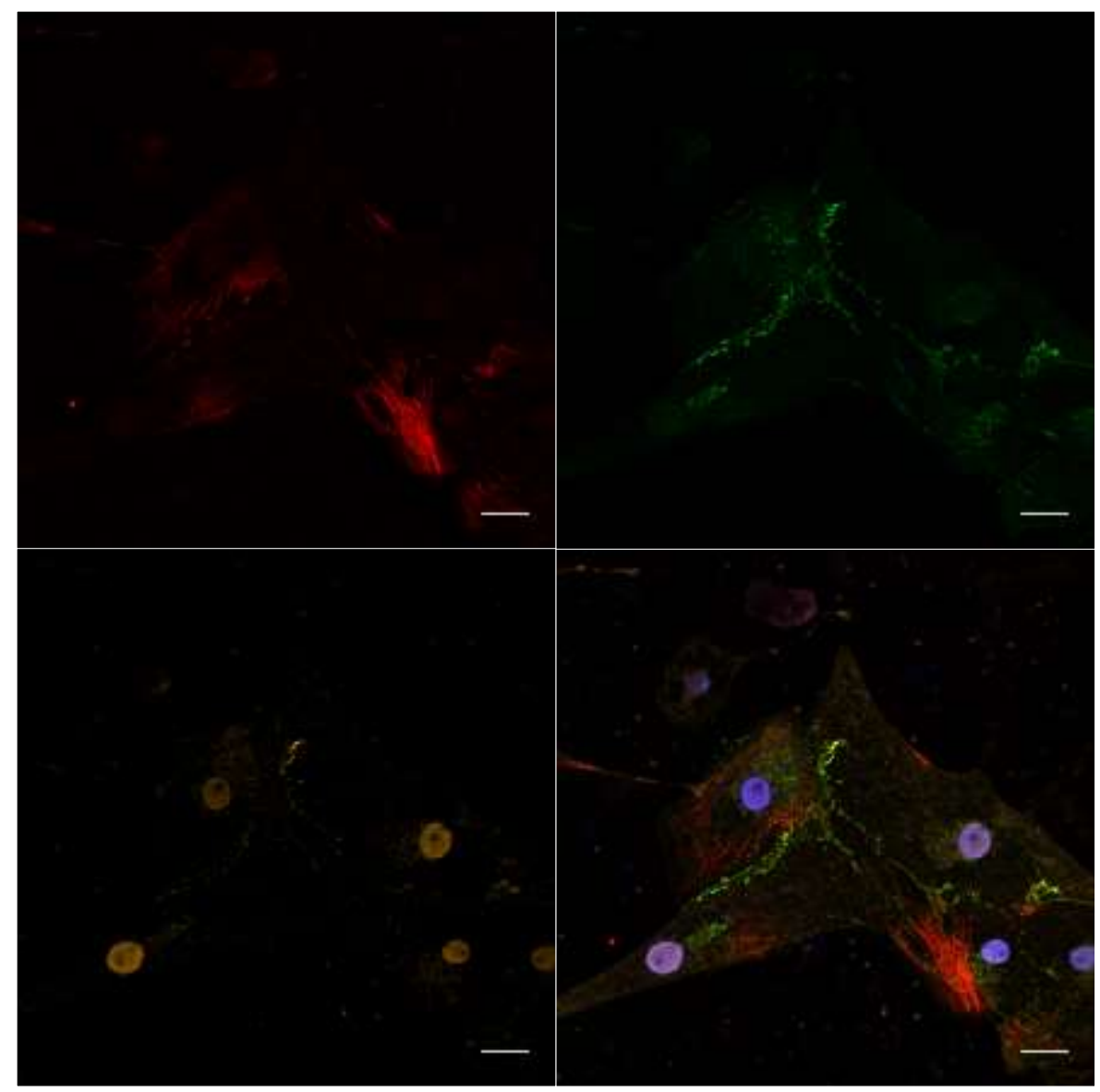

Figure 16: Fluorescence image of RhiPS derived cardiomyocytes

Positive staining of $\alpha$-actinin (red) and Tbx-5 (yellow) indicate successful differentiation of RhiPS through mesoderm induction into cardiomyocytes. Positive connexin 43 (green) staining identifies gap junctions between neighboring cardiomyocytes. DNA labelled in blue. Scale bars: $20 \mu \mathrm{m}$.

\subsection{Mamu screening}

Targeted RNA-sequencing of transcripts encoding for Mamu antigens confirmed the identity of the C1 source fibroblasts and C1 iPS cell culture (Table 11). Sendai iPS cells were, as anticipated, clearly distinct from the $\mathrm{C} 1$ line as to Mamu haplotypes. 
Mamu expression was similar in Sendai iPS cell-derived cardiomyocytes with and without LPS and INFY stimulation.

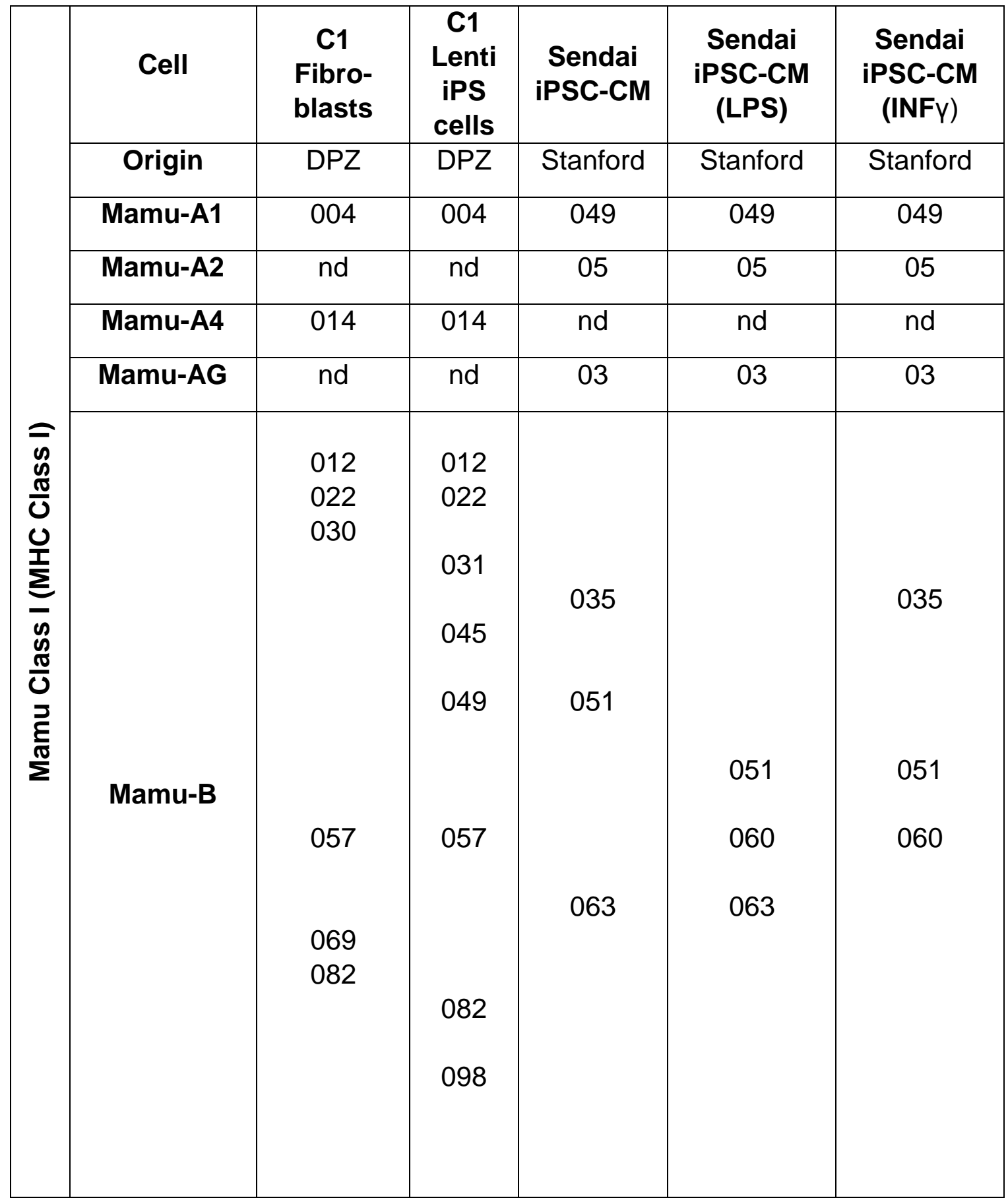

Table 11: Rhesus macaque MHC Class I (Mamu) antigen screening

RNA sequencing was performed using Rhesus Lenti-iPS origin fibroblasts, Lenti-iPS, Sendai iPS (undifferentiated), and Sendai iPS cardiomyocytes with and without stim- 
ulation with "pro-inflammatory cytokines". Sequencing was performed at the TALGöttingen. Sequencing analysis performed by Angela Noll (DPZ). Nd: not detected.

\subsection{Teratoma assay}

Teratoma formed in three out of four NOD-SCID mice injected with Sendai RhiPS cells. Two teratoma were removed 35 days post injection and had sizes of $314 \mathrm{~mm}^{3}$ and $297 \mathrm{~mm}^{3}$ and weights of $0.53 \mathrm{~g}$ and $0.36 \mathrm{~g}$, respectively. The third teratoma was resected after 42 days with a diameter of $236 \mathrm{~mm}^{3}$ and weight of $0.38 \mathrm{~g}$. The fourth mouse developed no teratoma after 91 days. Teratomas were sectioned and stained with hematoxylin and eosin for embryonic germ layer identification (Figure 17).

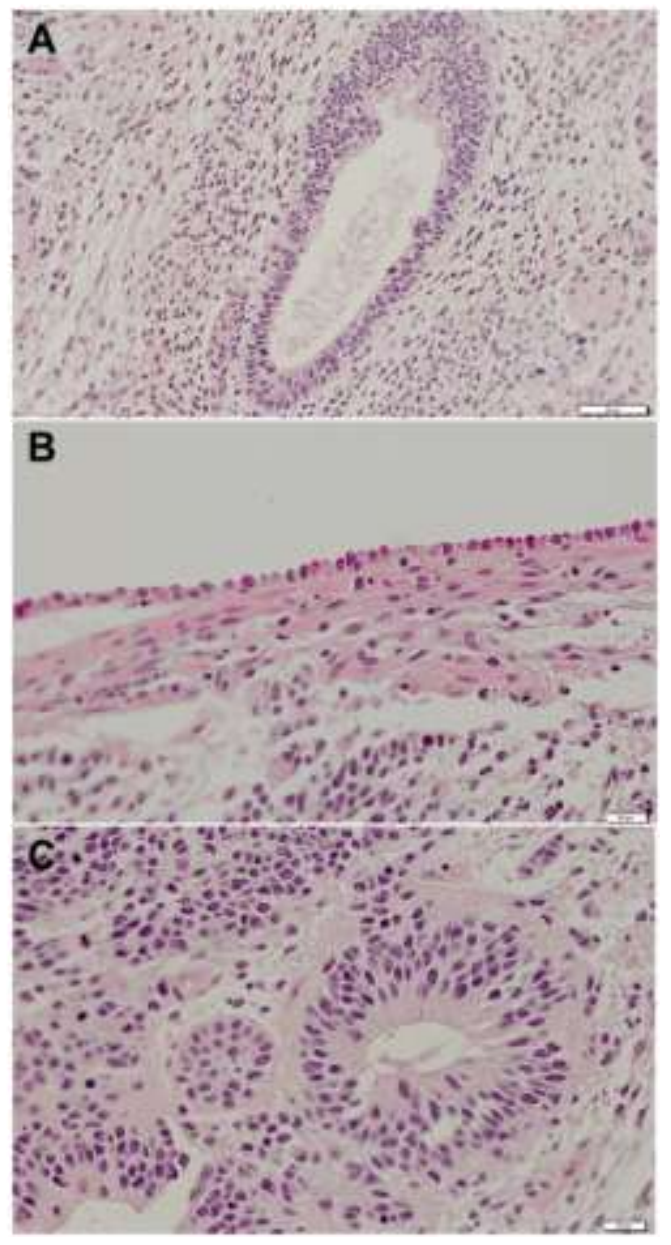

Figure 17: Teratoma assays confirmed pluripotency in Sendai RhiPS cells

H\&E staining of teratoma in NOD SCID mice after subcutaneous injection of undifferentiated Sendai RhiPS cells. Structures suggesting endoderm (A), mesoderm (B), 
and ectoderm (C) development. Study performed by Prof. R. Dressel. Scale bars: 20 $\mu \mathrm{m}$

\subsection{EHM Isometric force measurement}

Spontaneous beating of Lenti-iPS-EHMs was detected at the earliest 10 days after EHMs were cast. This corresponds to approximately 7 days following the suspension of the EHMs on the dynamic mechanical stretch devices. EHM contractions were observed until EHM culture day 28. Spontaneous beating of Sendai RhEHMs was detected earliest at 13 days after EHMs were cast. This corresponds to approximately 10 days following the suspension of the EHMs on dynamic mechanical stretch devices. Isometric force measurements revealed positive inotropic responses to increasing concentrations of extracellular calcium with similar forces in Lenti-EHM ( $\mathrm{n}=$ 23 ) and Sendai-EHM ( $n=27$; Figure 18$)$. An apparent calcium sensitivity $\left(E_{50}\right)$ was calculated for both iPS cell line at $0.8 \pm 0.03 \mathrm{mmol} / \mathrm{L}\left[\mathrm{Ca}^{2+}\right](\mathrm{n}=50$; Figure 19).

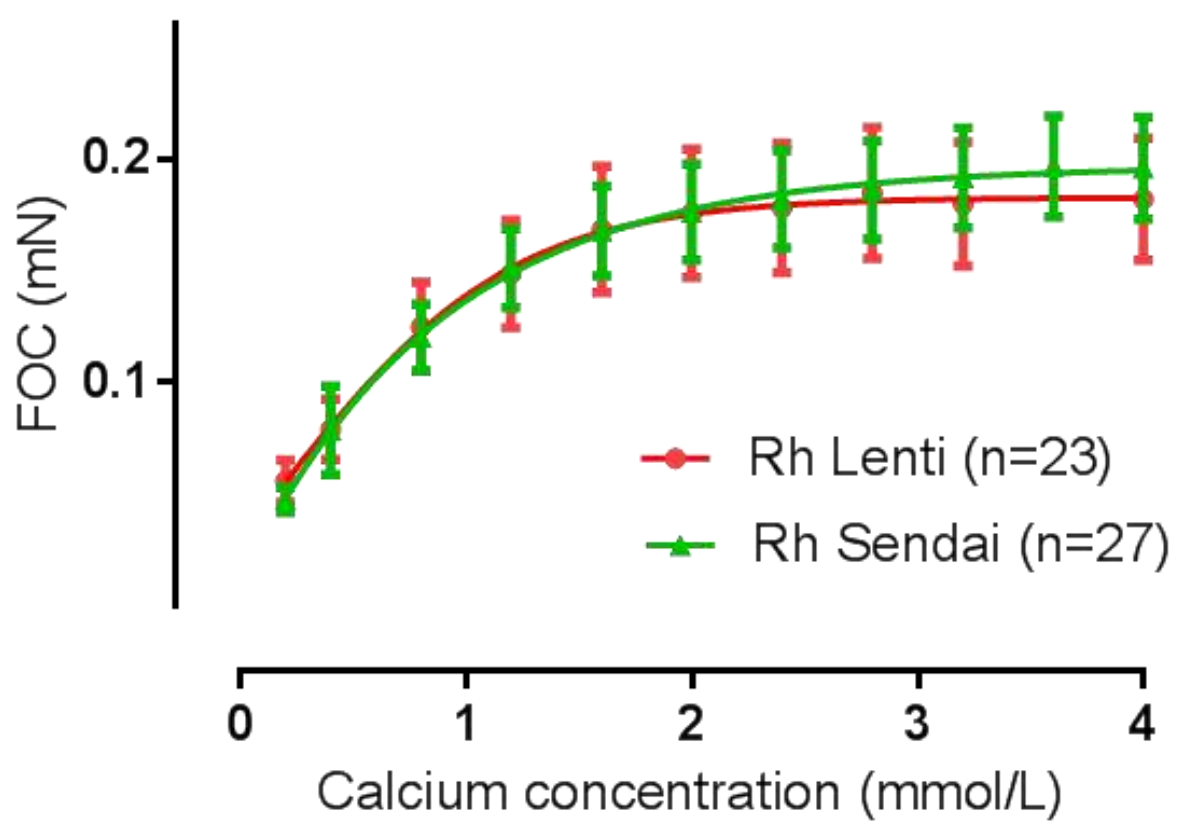

Figure 18: Calcium concentration response in the two tested iPS cell-derived EHM.

Isometric force measurements performed at $37^{\circ} \mathrm{C}$ and under electrical field stimulation at $1.5 \mathrm{~Hz}$ in EHM generated either from Lenti- (Lentivirus) or Sendai-iPS- 
cardiomyocytes. Extracellular calcium was cumulatively increased as indicated on the abscissa. FOC: force of contraction in $\mathrm{mN}$.

Testing response to the classical positive inotrope isoprenaline $(1 \mu \mathrm{mol} / \mathrm{L})$ revealed that $\beta$-adrenergic responsiveness was similarly developed in either EHM format (Figure 19).

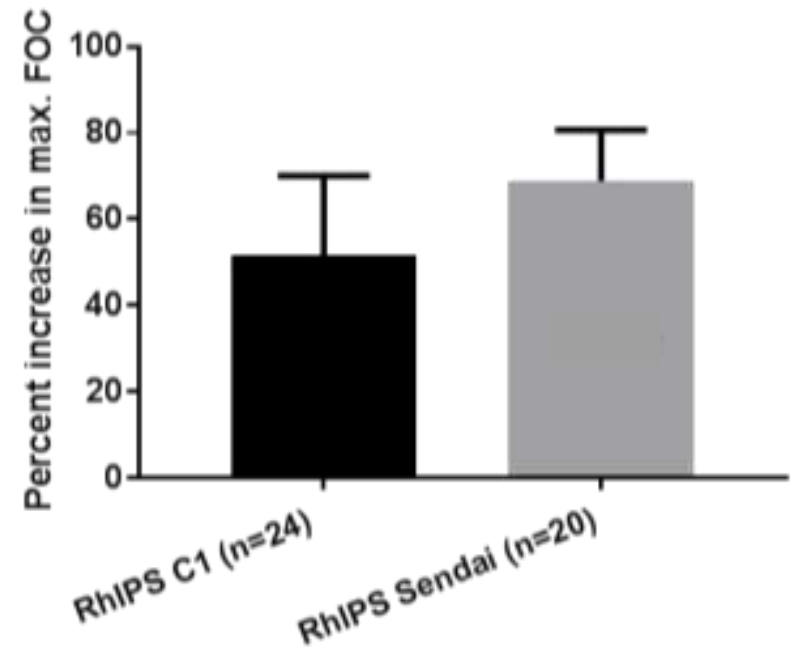

\section{Figure 19: Positive inotropic responses to isoprenaline in Rhesus EHM}

Isometric force measurements performed at $37{ }^{\circ} \mathrm{C}$ and under electrical field stimulation at $1.5 \mathrm{~Hz}$ in EHM generated either from Lenti- or Sendai-iPS cell-derived cardiomyocytes. Extracellular calcium was individually adapted to $\mathrm{EC}_{50}$ prior to bolus stimulation with isoprenaline $(1 \mu \mathrm{mol} / \mathrm{L})$. Positive ionotropic responses were generated in both Lenti EHM and Sendai EHM resulting in an increased FOC of $51 \pm 18 \%$ $(n=24)$ and $69 \pm 12 \%(n=20)$ respectively. ${ }^{*} P<0.05$; one-tailed student $T$ test. FOC: Force of Contraction

A positive force frequency behavior is considered a sign of advanced myocardial maturation. In contrast to human EHM developed under a similar protocol, force frequency behavior appeared negative in Rhesus EHM (Figure 20). 


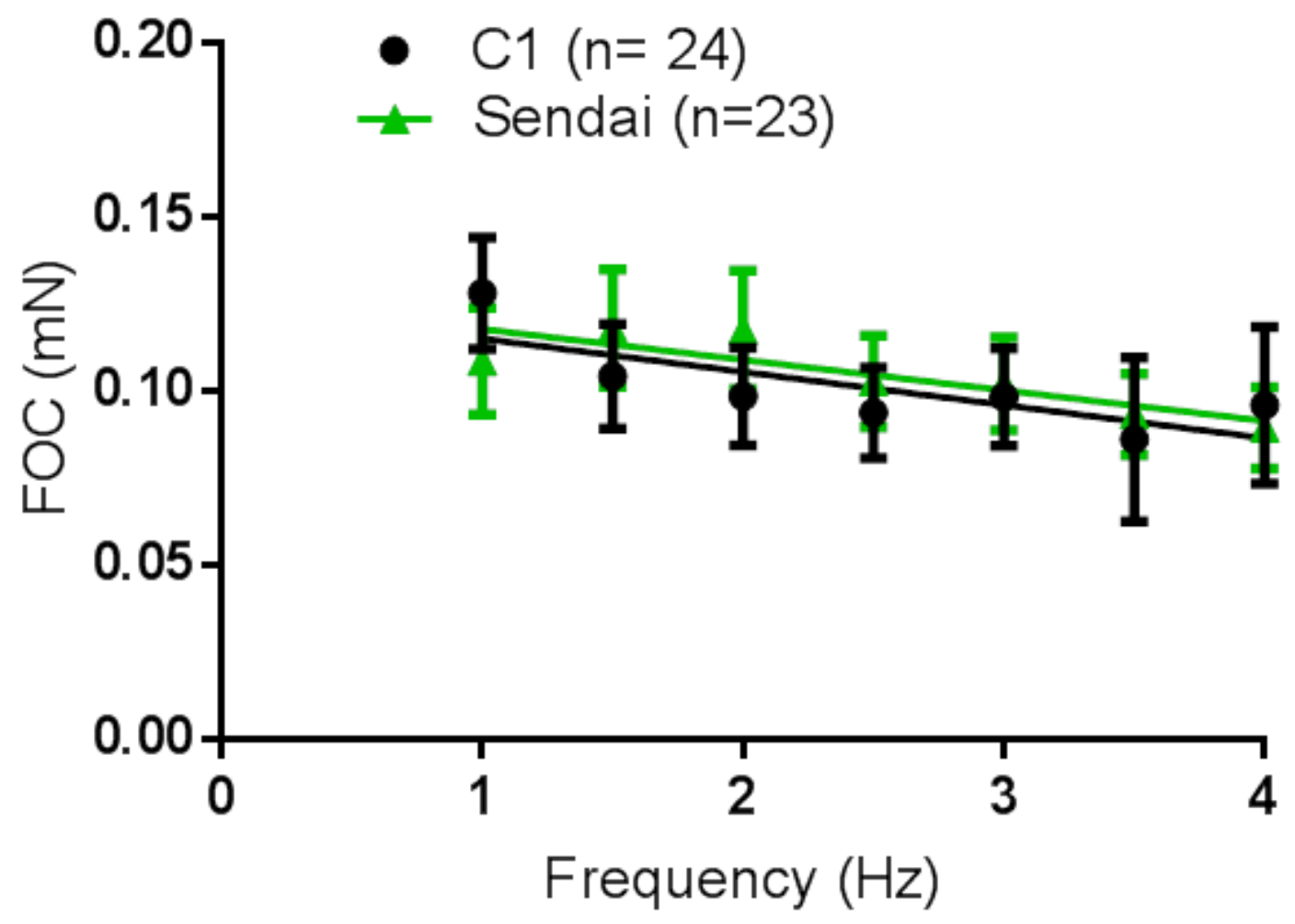

Figure 20: Negative force-frequency response in Rhesus EHM.

Isometric force measurements performed at $37^{\circ} \mathrm{C}$ and under electrical field stimulation at the indicated stimulation frequencies in EHM generated either from Lenti- or Sendai-iPS cell-derived cardiomyocytes. Extracellular calcium concentration was maintained at $0.8 \mathrm{mmol} / \mathrm{L}$ for the duration of the experiment.

\subsection{EHM cardiomyocyte content}

Following isometric force measurements, EHMs were dissociated and analyzed via flow cytometry for $\alpha$-actinin positive staining to identify the EHM cardiomyocyte content. Lenti-EHMs contained $66 \pm 1 \%(n=3)$ cardiomyocytes (Figure 21A). Average cardiomyocyte content in Sendai-EHM was $84 \pm 2 \%(n=3$; Figure 21B). Total cell number per EHM was 189,500 \pm 12,251 and 995,733 $\pm 206,107$ in Lenti- and Sendai-EHM, respectively. 

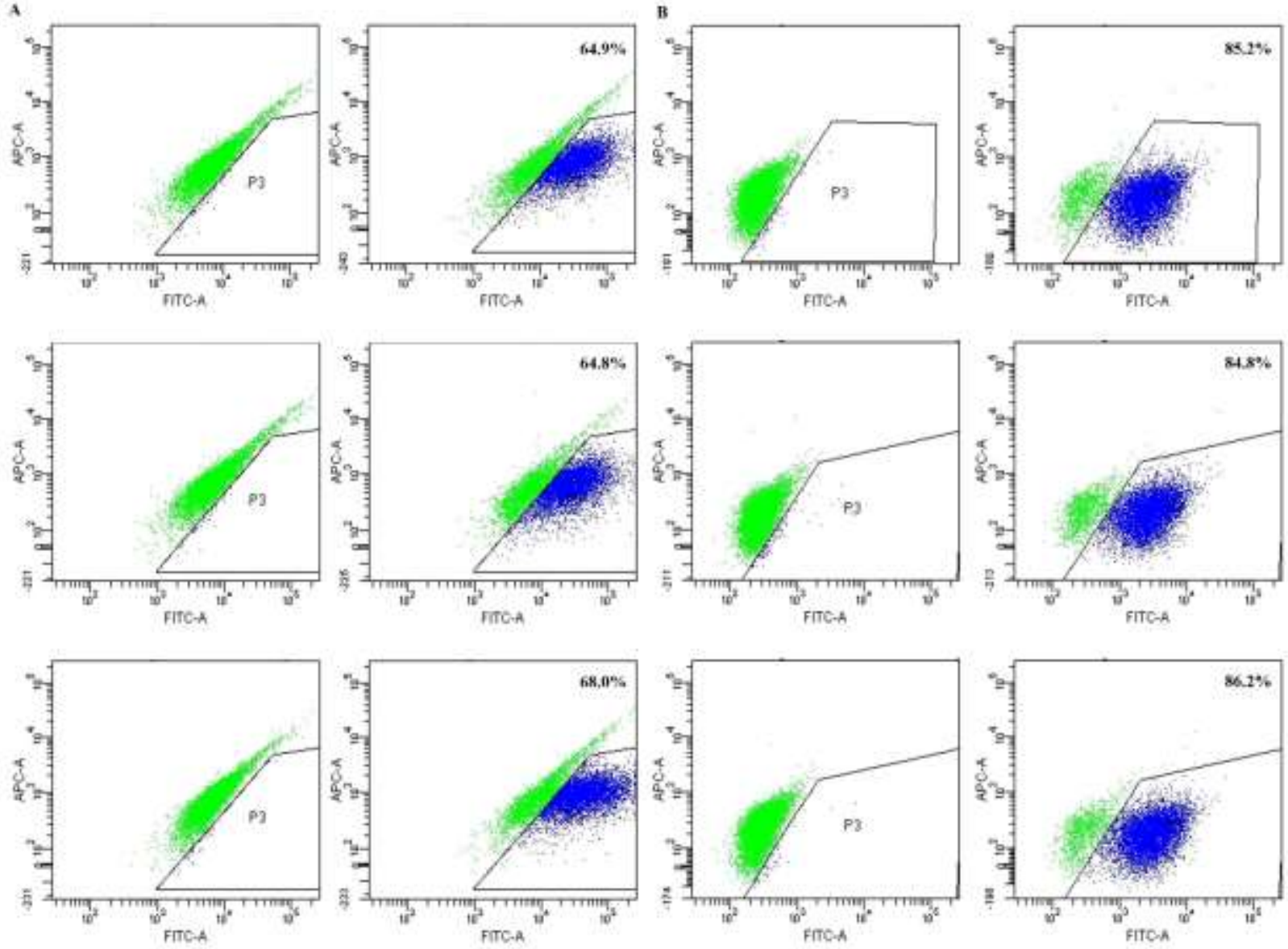

\section{Figure 21: Cardiomyocyte content of Rhesus EHM.}

Flow cytometry analysis of a-actinin cardiomyocytes in EHM. Analyses were performed in EHM subjected to contraction experiments. A) Cardiomyocyte content in Lenti-iPS cell EHMs (n=3). B) Cardiomyocyte content in Sendai-iPS cell EHMs $(n=3)$. Original flow cytometry plots are displayed from all experiments. The cardiomyocyte gate (P3) was set based on the signal obtained from isotype control experiments (green cell population).

Whole mount staining was performed to visualize the structural arrangement of RhiPS-derived cardiomyocytes in EHM (Figure 22). Staining for a-sarcomeric actinin and $f$-actin revealed heart muscle network formation. 


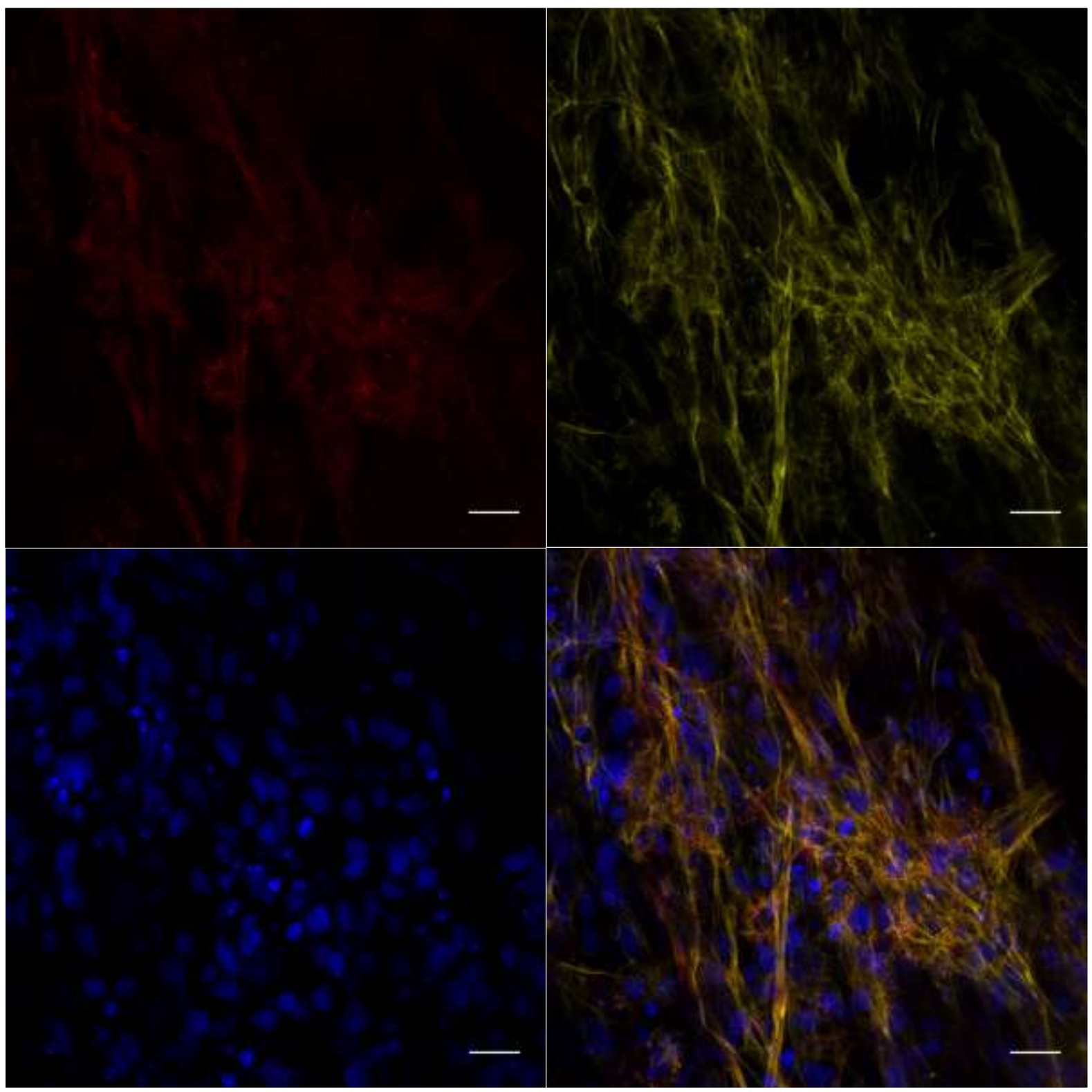

Figure 22: Whole mount staining of RhEHM.

Whole mount EHM with immune labeling of $\alpha$-actinin (red) and f-actin (green). DNA (blue). Scale bars: $20 \mu \mathrm{m}$.

\subsection{EHM post transplantation gene expression}

EHMs generated from Lenti-iPS cell-derived cardiomyocytes were transplanted into non-infarcted nude rats for four weeks (performed by the Wu lab at Stanford, US). Following euthanasia and excision of the hearts no teratoma were observed. Subsequently, RNA was extracted for qPCR analysis for the expression of pluripotency and cardiac marker transcripts. Expression of pluripotency genes POU5F1 and MYC 
were found to be $61 \%$ and $27 \%$ higher than in monolayer differentiated cardiomyocytes from Sendai iPS cells, respectively (Table 12). Cardiomyocyte markers were much less abundant in the Lenti-EHM compared to the Sendai iPS cell-derived cardiomyocyte cultures.

\begin{tabular}{|l|c|c|}
\hline \multicolumn{3}{|c|}{ RNA expression ratio } \\
\hline & $\begin{array}{c}\text { Lenti-EHM } \\
\text { (explant) }\end{array}$ & $\begin{array}{c}\text { Sendai } \\
\text { Cardiomyocyte }\end{array}$ \\
\hline Rhesus GAPDH & 1 & 1 \\
\hline POU5F1 & 60.97876003 & 0.999908 \\
\hline ABCG2 & 0.990132138 & 0.999659 \\
\hline MYC & 26.94916477 & 0.989154 \\
\hline MYL2 & 0.004635175 & 0.884931 \\
\hline MYH7 & 0.000123657 & 0.255618 \\
\hline MYH6 & 0.007126534 & 0.224855 \\
\hline TNNT2 & 0.015418664 & 0.241777 \\
\hline NKX25 & 0.008650089 & 0.962193 \\
\hline
\end{tabular}

Table 12: Comparative RNA expression of pluripotency and cardiomyocyte marker genes in Lenti-EHM explants and Sendai-cardiomyocytes.

Following four-week implantation in nude rats, a Lenti-EHM $(n=1)$ was excised and a comparison of pluripotency (blue) and cardiomyocytes (red) marker gene expression levels with Sendai iPS cell-derived cardiomyocyte monolayer culture $(n=1)$ was performed via qPCR. Data provided from the Wu laboratory, Stanford University. Data was normalized to GAPDH.

The high level of Rhesus POU5F1 and MYC was taken as a sign of an activation of endogenous stemness markers and thus thought to be suboptimal for further development of the Lenti-EHM approach. 


\subsection{Superovulation and oocyte retrieval of Rhesus macaque oocytes}

As an alternative to iPS cells, parthenogenetic stem cells (pSC) may evolve as a more immune privileged cell source (Didie et al. 2013). To translate earlier work into large animal models, oocytes from five female macaques were collected following three separate hormone-induced superovulation cycles with a one month break inbetween cycles for hormone clearance. Super ovulation was monitored via ultrasound examination to track progression of follicle growth and to identify if a longer cycle of hormone injections was required (Figure 23). Follicle aspiration was employed for ovulation cycle 1 and ovulation cycle 2, whereas complete ovariectomy was performed following ovulation cycle 3 (Figure 24). Ovaries from a sixth female were provided by the DPZ after necropsy. Oocytes retrieved from ovaries of the sixth monkey were subjected to an IVM protocol (Section 2.2.6) in attempt to develop MII oocytes in vitro.

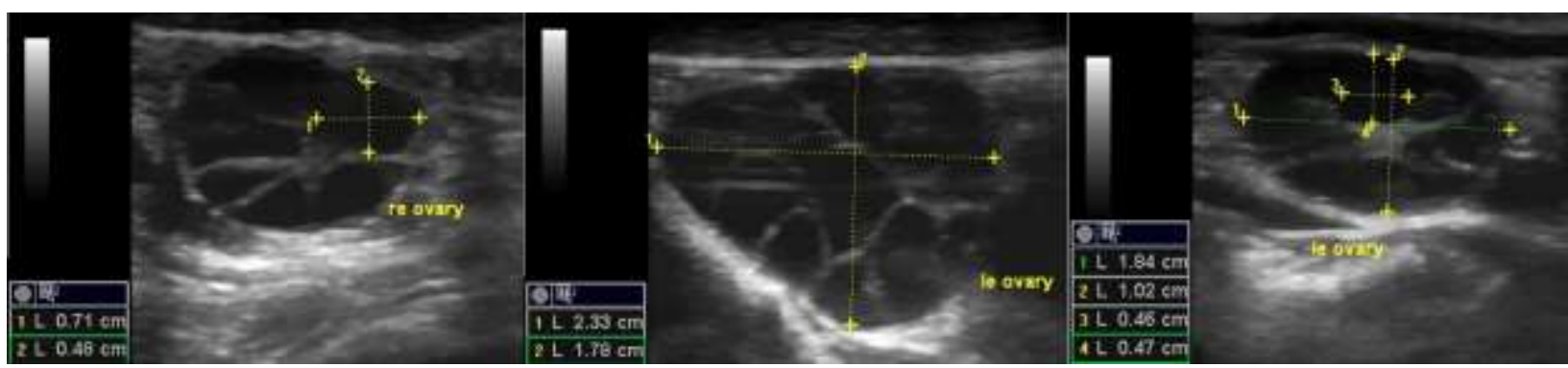

Figure 23: Ultrasound examination of hormone stimulated Rhesus ovaries.

Ultrasound examination of Rhesus macaques 2616 (Left), 2551 (middle), and 2500 (right) during super ovulation cycle 3 show stimulated ovaries with multiple follicles having diameter lengths ranging from $0.46 \mathrm{~cm}$ to $0.71 \mathrm{~cm}$ (optimal follicle diameter is $>0.6 \mathrm{~cm}$ ). Monkeys with ovaries that had smaller and/or fewer follicles received additional hormone injections. L: length in $\mathrm{cm}$; re: right; le: left. 


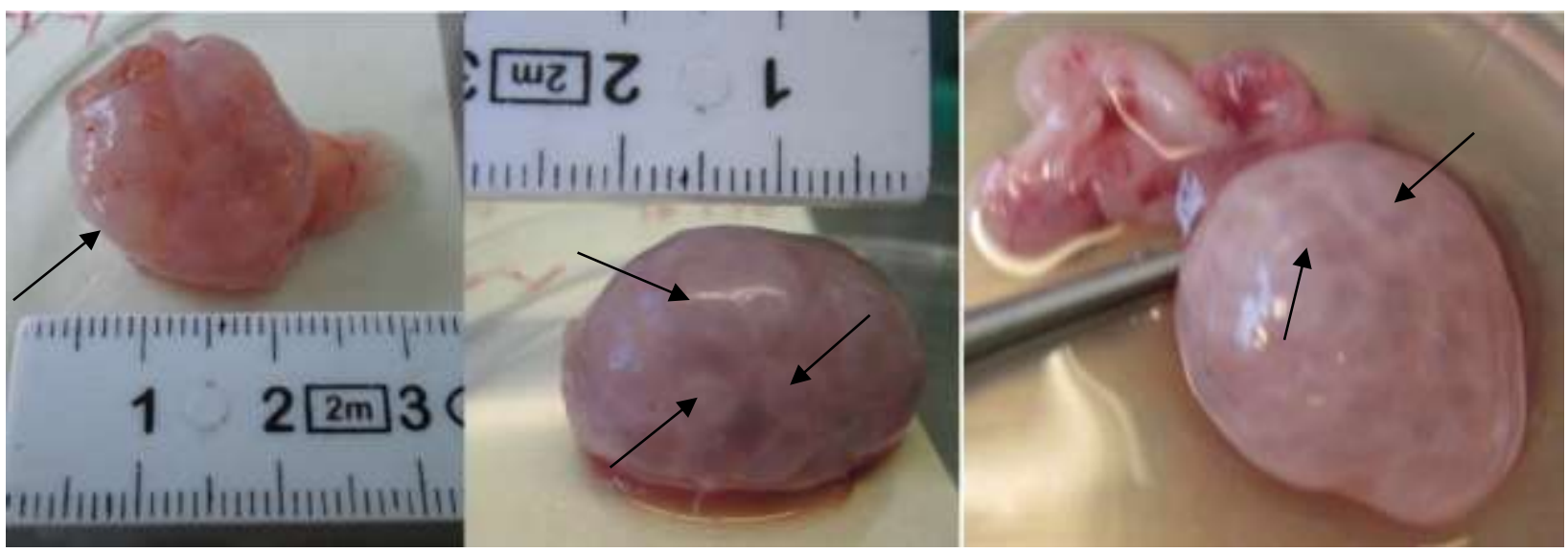

Figure 24: Excised ovaries from super-ovulated Rhesus macaques

Ovaries were excised by bilateral ovariectomy from Rhesus macaques 2551 (Left), 2616 (middle), and 2506 (right) after hormone induced superovulation. Ovary diameters ranged between $2 \mathrm{~cm}$ and $3 \mathrm{~cm}$ and contained multiple enlarged follicles (arrows).

A total of 224 oocytes were collected from five female Rhesus macaques over the course of three hormone-induced superovulation cycles. An additionally 23 oocytes were collected from a sixth monkey (\#2379), not originally included in the study, that was euthanized for medical reasons by the veterinarians at the DPZ. 38 oocytes were harvested from five monkeys after superovulation cycle 1 ( $8 \pm 3$ /macaque) and a total of 34 for superovulation cycle 2 ( $7 \pm 2$ /macaque). Harvesting of oocytes was greatly increased in superovulation cycle 3 to a total of 152 (30 \pm 8 /macaque) due to having the full ovary available for dissection (Figure 25). In the case of the sixth monkey 23 oocytes were collected and subjected to in vitro maturation. 


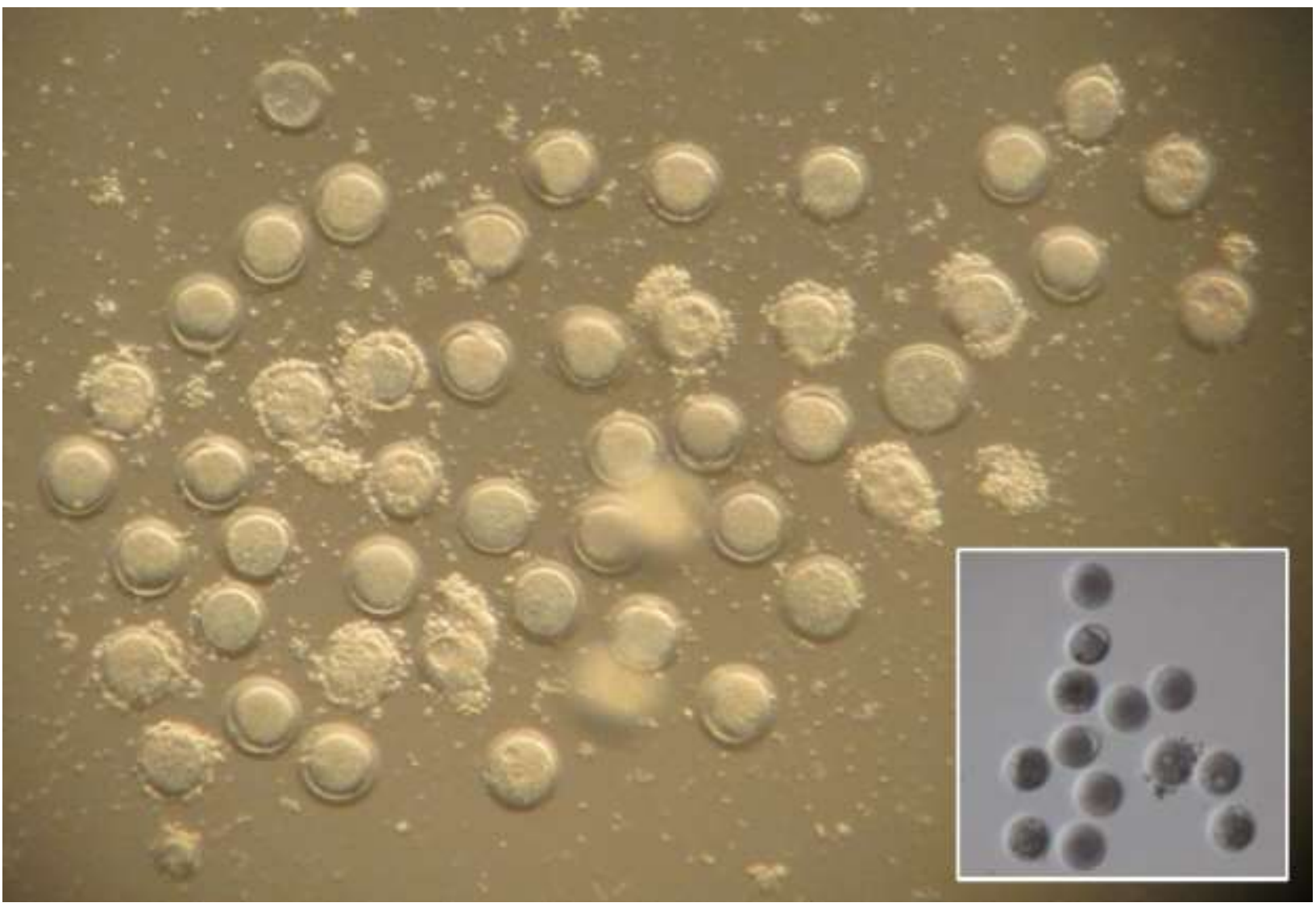

Figure 25: Oocytes collected from excised ovaries

A larger number of oocytes from Rhesus \#2506 were collected from whole ovaries following bilateral ovariectomy when compared to number of eggs collected via follicle aspiration (inset).

\subsection{Activation of retrieved oocytes}

Successfully retrieved oocytes from hormone-induced superovulated ovaries were exposed to $0.5 \mathrm{mg} / \mathrm{ml}$ hyaluronidase (Type IV; Sigma Aldrich) for 5-10 minutes to remove the cumulus cells. Oocytes were then washed three times with TALP-Hepes medium. Activation of oocytes was performed with exposure to a calcium ionophore (lonomycin) followed by either 6-DMAP or puromycin. We obtained an overall average activation rate $27 \pm 0.1 \%(n=16)$ from all oocyte collections (superovulation + IVM). In all ovulation cycles, activation was classified as cells that either divided or fragmented following activation with lonomycin. Oocytes that remained intact single cells were not considered to be activated. 
During normal fertilization, preimplantation embryo development progression consists of an initial division from 1 to 2 cells 24 hours after fertilization. Further cell divisions occur approximately every 12-18 hours thereafter until the morula stage at which point the cells become autonomous in their division cycles (Braude et al. 1988, Chason et al. 2011). We were able to obtain precise timepoints of cellular divisions using the video-optic capabilities of the Embryoscope ${ }^{\mathrm{TM}}$. Image analysis indicated that successfully activated Rhesus oocytes followed approximately this same cell division timeline as occurs in normal fertilization (Figure 26).

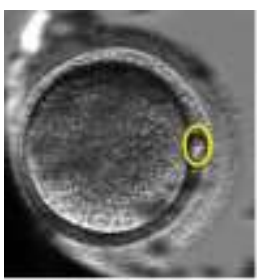

$7 \mathrm{hr}$

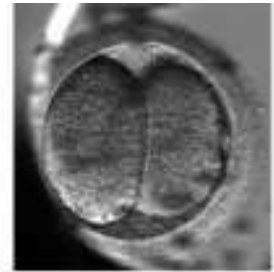

$23.5 \mathrm{hr}$

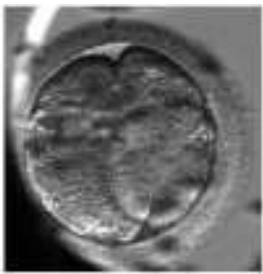

$34.8 \mathrm{hr}$

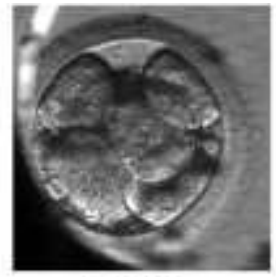

$46.8 \mathrm{hr}$

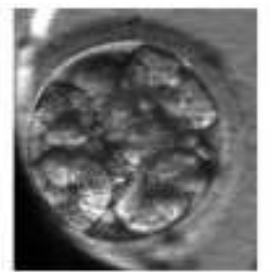

$70 \mathrm{hr}$

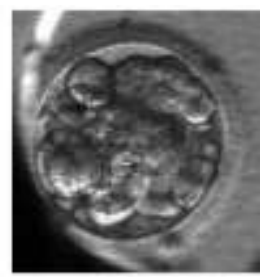

$96.8 \mathrm{hr}$

Figure 26: Cellular division of activated Rhesus oocytes

Following successful chemical activation, oocytes begin division after 24 hours and continue dividing approximately every $12-18$ hours to the morula stage at which point cells division becomes autonomous. Yellow circle depicts first polar body extrusion signifying an MII oocyte.

Oocytes from ovulation cycle 1 were exposed to 6-DMAP for 4 hours in attempt to block $1^{\text {st }}$ polar body $(\mathrm{PB})$ extrusion, which would result in a partially heterozygous pSC (Figure 3). A total of 14 oocytes were activated from the 38 oocytes collected (37\%; Table 13). A total of 9 activated oocytes (24\% of total) progressed to the morula stage and were transferred onto feeder cultures (Figure 27A).

\begin{tabular}{|l|l|l|l|l|l|l|}
\hline Rhesus & $\# 2500$ & $\# 2616$ & $\# 2483$ & $\# 2506$ & $\# 2551$ & Total \\
\hline Collected & 3 & 3 & 7 & 20 & 5 & 38 \\
\hline Activated & 1 & 1 & 5 & 7 & 0 & 14 \\
\hline Activation rate & $33 \%$ & $33 \%$ & $71 \%$ & $35 \%$ & $0 \%$ & $37 \%$ \\
\hline 2 cell & 0 & 1 & 4 & 4 & 0 & 9 \\
\hline
\end{tabular}




\begin{tabular}{|l|l|l|l|l|l|l|}
\hline 4 cell & 0 & 1 & 4 & 4 & 0 & 9 \\
\hline 8 cell & 0 & 1 & 4 & 4 & 0 & 9 \\
\hline Morula & 0 & 1 & 4 & 4 & 0 & 9 \\
\hline Transferred & 0 & 1 & 4 & 4 & 0 & 9 \\
\hline
\end{tabular}

Table 13: Oocyte activations of Rhesus macaques from ovulation cycle 1

Oocytes from 5 female macaques were collected via follicle aspiration and activated with ionomycin and 6DMAP treatment. Long term cultures were performed as clusters of oocytes in medium drops in a humidified cell culture incubator. 9 activated oocytes were transferred into feeder layer cultures.

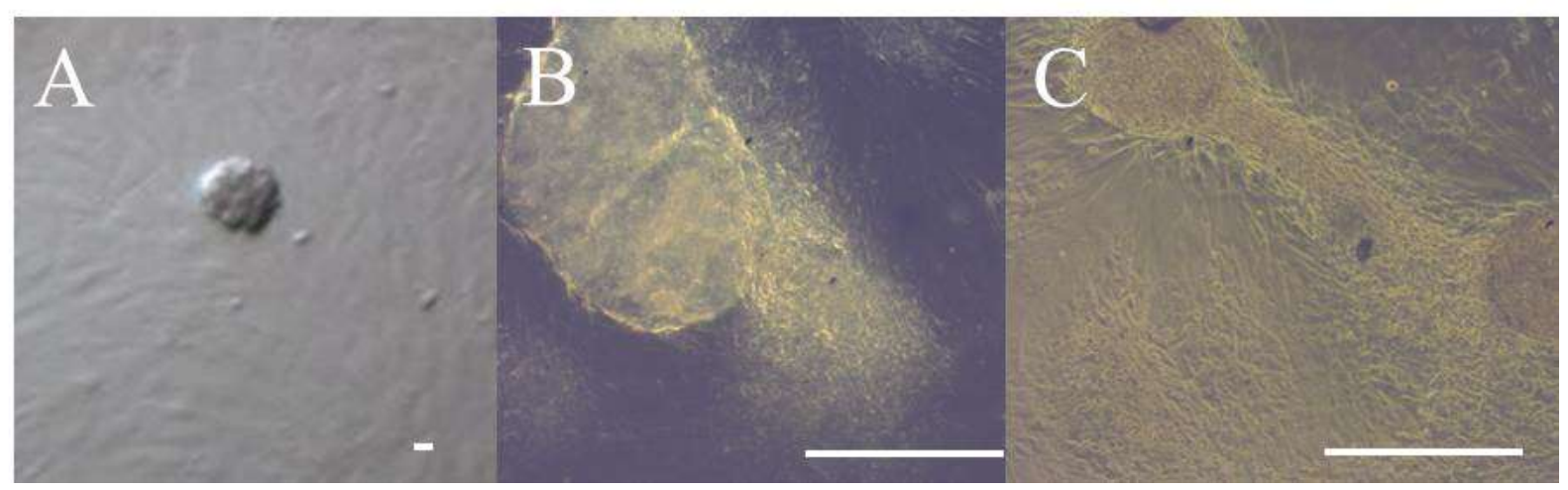

Figure 27: Rhesus ICM plating

Inner cell mass of activated Rhesus oocyte plated onto inactivated human fibroblasts (A). Cellular outgrowths from Rhesus parthenote blastomeres (B and C). Scale: 50 $\mu \mathrm{m}$

Oocytes from ovulation cycle 2, ovulation cycle 3 and IVM cycles were exposed to puromycin for 5 hours in attempt to block $2^{\text {nd }} P B$ extrusion which would result in a fully homozygous pSC (Figure 3). A total of 13 oocytes were activated from a total of 38 oocytes collected from ovulation cycle 2 (38\%; Table 14). All 13 activated oocytes progressed to the 8-cell stage however, only 11 progressed into the morula stage and were transferred onto feeder cultured (32\% of total). 


\begin{tabular}{|l|l|l|l|l|l|l|}
\hline Rhesus & $\# 2500$ & $\# 2616$ & $\# 2483$ & $\# 2506$ & $\# 2551$ & Total \\
\hline Collected & 4 & 14 & 1 & 5 & 10 & 34 \\
\hline Activated & 0 & 8 & 0 & 5 & 0 & 13 \\
\hline Activation rate & $0 \%$ & $57 \%$ & $0 \%$ & $100 \%$ & $0 \%$ & $38 \%$ \\
\hline 2 cell & 0 & 8 & 0 & 5 & 0 & 13 \\
\hline 4 cell & 0 & 8 & 0 & 5 & 0 & 13 \\
\hline 8 cell & 0 & 8 & 0 & 5 & 0 & 13 \\
\hline Morula & 0 & 8 & 0 & 3 & 0 & 11 \\
\hline Transferred & 0 & 8 & 0 & 3 & 0 & 11 \\
\hline
\end{tabular}

Table 14: Oocyte activations of Rhesus macaques from ovulation cycle 2

Oocytes from 5 female macaques were collected via follicle aspiration and activated with ionomycin and puromycin treatment. Long term cultures were performed as clusters of oocytes in medium drops in a humidified cell culture incubator. 11 activated oocytes were transferred into feeder layer cultures.

A total of 22 oocytes were activated from a total of 152 oocytes collected from ovulation cycle 3 (14\%; Table 15). Only 3 oocytes from 22 activated ( $2 \%$ of total) progressed to morula stage, however, due to the better monitoring capabilities by videooptic recordings of the developmental process via an automated Embryoscope ${ }^{\mathrm{TM}} 12$ activated oocytes at different stages of division were transferred onto feeder layers. Two of the transferred parthenotes from macaques \#2551 and \#2616 began cellular outgrowths onto the feeder cultures (Figure 27B and C).

\begin{tabular}{|l|l|l|l|l|l|l|}
\hline Rhesus & $\# 2500$ & $\# 2616$ & $\# 2483$ & $\# 2506$ & $\# 2551$ & Total \\
\hline Collected & 27 & 16 & 19 & 58 & 32 & 152 \\
\hline Activated & 2 & 8 & 2 & 6 & 4 & 22 \\
\hline Activation rate & $7 \%$ & $50 \%$ & $11 \%$ & $10 \%$ & $13 \%$ & $14 \%$ \\
\hline 2 cell & 2 & 5 & 0 & 5 & 2 & 14 \\
\hline 4 cell & 2 & 2 & 0 & 2 & 0 & 6 \\
\hline 8 cell & 1 & 2 & 0 & 1 & 0 & 4 \\
\hline
\end{tabular}




\begin{tabular}{|l|l|l|l|l|l|l|}
\hline Morula & 0 & 2 & 0 & 1 & 0 & 3 \\
\hline Transferred & 2 & 7 & 0 & 1 & 2 & 12 \\
\hline
\end{tabular}

Table 15: Oocyte activations of Rhesus macaques from ovulation cycle 3

Oocytes from 5 female macaques were collected from ovaries following bilateral ovariectomy, activated with ionomycin and puromycin treatment. Long term culture was performed in an Embryoscope ${ }^{\mathrm{TM}}$ as single cells in a culture well under constant video-optic monitoring. 12 activated oocytes were transferred into feeder layer cultures and 2 blastomeres developed outgrowths.

A total of 2 oocytes were activated from a total of 23 oocytes collected from unstimulated ovaries of a sixth Rhesus (\#2379) that was euthanized for medical reasons by the veterinarians at the DPZ. The oocytes underwent 24 hours of in vitro maturation prior to parthenogenetic activation. Only 1 activated oocyte was transferred onto feeder layer cultures in attempt to propagate 4-cell outgrowths (Table 16).

\begin{tabular}{|l|l|}
\hline Rhesus & $\# 2379$ \\
\hline Collected & 23 \\
\hline Activated & 2 \\
\hline Activation rate & $9 \%$ \\
\hline 2 cell & 2 \\
\hline 4 cell & 1 \\
\hline 8 cell & 0 \\
\hline Morula & 0 \\
\hline Transferred & 1 \\
\hline
\end{tabular}

\section{Table 16: Oocyte activation of Rhesus \#2379}

Oocytes from Rhesus \#2379 were collected from unstimulated ovaries following euthanasia by veterinarians at the DPZ for medical reasons. Oocytes were subjected to in vitro maturation prior to parthenogenetic activation. 1 Oocyte was successfully activated and transferred into feeder layer cultures after progressing to the 4-cell stage of development. 
The bar graph in Figure 28 summarizes the data from all Rhesus macaque oocyte retrievals and activations.

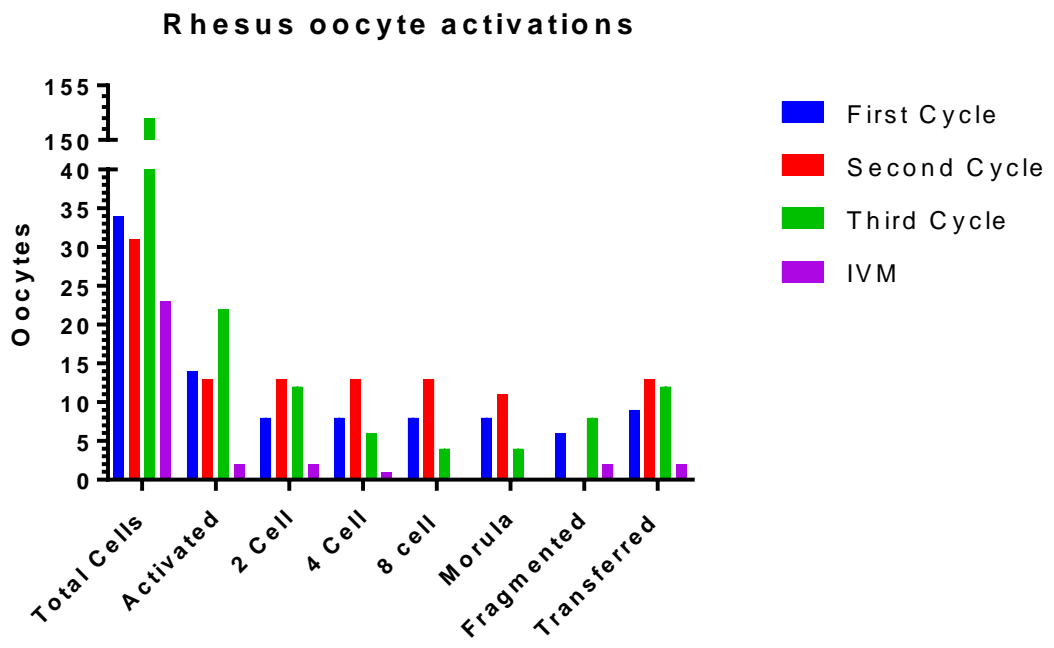

Figure 28: Summary of all Rhesus macaque oocyte activations.

Oocytes were retrieved either by follicle aspiration (cycle 1 and 2) or ovariectomy (cycle 3) after superovulation or necropsy followed by in vitro maturation (IVM). Parthenogenetic activation was either by lonomycin/6-DMAP $\left(1^{\text {st }}\right.$ cycle) or lonomycin/Puromycin $\left(2^{\text {nd }}, 3^{\text {rd }}\right.$ cycles, and IVM). 


\section{Discussion}

Heart failure is an increasing social and economic burden across the globe. In recent years therapeutic strategies for the repair of damaged myocardium through tissue replacement have intensified (Feric and Radisic 2016). These investigations have shown promising results in the treatment of heart failure not only in providing paracrine support (Wei et al. 2015, reviewed in Ye et al. 2013) to slow the progression, but also in providing a contractile function to the failing heart (Riegler et al. 2015, Shiba et al. 2012, Weinberger et al. 2016). These studies, it must be noted, were performed in small animal models.

As reviewed in Plews et al (2012) current rodent models are not optimal predictors of efficiency and safety for clinical application, because of their short life span, rapid heart rate and most importantly, the fundamental difference between rodent and human cardiomyocyte morphology and physiology. In order for stem cell based therapeutics to become a viable therapeutic option for the treatment of heart failure, basic scientific findings derived from rodent models must be replicated in a clinically relevant large animal model (Harding et al. 2013, Ogle et al. 2016). Multiple large mammalian species have been used to test the safety and efficacy of stem cell treatments in heart failure caused by myocardial infarction. However, most of these studies utilized xenograft transplantation of human cells into immune suppressed animals such as pig and dog (van der Spoel et al. 2011), sheep (Dayan et al. 2016) and nonhuman primate (Blin et al. 2010, Chong et al. 2014). The lack in pluripotent stem cell models in pigs, sheep, and dogs makes the non-human-primate, with well documented derivation of stem cells (Chen et al. 2008, Debowski et al. 2015, Fang et al. 2014, Liu et al. 2008, Wunderlich et al. 2014, Zhu et al. 2011), and here in particular the macaque model, the preferred large animal for auto- and allograft testing (Shiba et al. 2016). Smaller monkeys such as the common marmoset are, because of bone marrow chimerism in monoplacental species, less suited for transplant studies (Averdam et al. 2007, Genain et al. 1994). Thus, this dissertation focused on Rhesus macaque pluripotent stem cell models, i.e., embryonic stem cells (ESCs), induced pluripotent stem cells (iPSCs), and parthenogenetic stem cells (pSCs). A Rhesus ESC line described in (Thomson et al. 1995) was obtained from WiCell, but could not be maintained in culture. In contrast, iPS cells derived in Göttingen and Stanford 
could be cultured and differentiated. First Rhesus pSCs were derived, but not yet further characterized.

The main findings of this dissertation can be summarized as follows:

- Rhesus macaque iPS cells can be directionally differentiated into spontaneously beating cardiomyocytes,

- EHM can be constructed from Rhesus macaque iPS cell derived cardiomyocytes,

- Rhesus macaque EHM have similar properties as human EHM, but appear functionally less mature (lack of a positive force frequency relationship),

- Sendai viral non-integrating reprogramming methods appear to be superior to lentivirally reprogramming of iPS cells in relation to their differentiation capacity and reduced likelihood of oncogene expression,

- Lenti-iPS cells required a preparatory alginate encapsulation approach for successful differentiation into cardiomyocytes,

- Rhesus macaque parthenogenetic stem cells can be derived from unfertilized oocytes after superovulation.

\subsection{RhiPS cells can differentiate into spontaneously beating cardiomyocytes}

To test the ability of stem cell based therapies in a large animal model to repair damaged myocardium, in which approximately 1 billion cells are lost, a reliable source of replacement cells must be available. Ideally, these cells should be allogeneic to the large animal model in which they will be tested. Previous investigations using allogeneic cells from NHPs include, stem cell derived cell sheets (Bel et al. 2010), cardiovascular progenitor cells (Blin et al. 2010) and iPS derived cardiomyocytes (Kawamura et al. 2016, Shiba et al. 2016). .In the study by Shiba et al (2016), iPS 
derived cardiomyocytes were shown to have a regenerative function in regards to repairing damaged myocardium similar to other studies using stem cells (reviewed in Der Sarkissian et al. 2017, Hao et al. 2017). Additionally, Kawamura et al (2016) were cable to show that there was a reduced immunological response to homozygous matched transplants. It must be noted that both studies used the Cynomolgus macaque (Macaca fascicularis) ESC and iPS cells respectively.

In this work, we focused on the Rhesus macaque (Macaca mulatta) as our NHP model and were able to successfully differentiate two independent RhiPS cell lines, Lenti- and Sendai-iPS cells, into spontaneously beating cardiomyocytes. Cardiomyocyte differentiation was achieved via small molecule and growth factor directed differentiation that has been proven to be highly effective in human cardiomyocyte differentation(Tiburcy et al. 2017). Cardiomyocyte purity of the RhiPS-derived cardiomyocytes ranged between $58 \pm 7 \%$ for the Lenti- to $91 \pm 3 \%$ for the Sendai-iPS cell lines. Previous protocols for the differentiation of Rhesus ESC into cardiomyocytes utilized the EB format. In this format, between 18\% (Schwanke et al. 2006) and 50\% (Leschik et al. 2008) of spontaneously beating EBs have been reported. More recently, monolayer differentiation cultures of RhiPS cells have also been shown to produce a cardiomyocyte purity of $92 \%$ based on cardiac troponin T positive staining (cTNT) (Zhang et al. 2017). In the studies by Kawamura at al. (2016) and Shiba et al. (2016) cardiomyocyte purities of $80 \%$ in EB culture and $84 \%$ in monolayer culture were achieved respectively.

Interestingly, human stem cell differentiation protocols in monolayer and EB cultures have been able to achieve purity levels ranging between 30-90\% cTNT positive, spontaneously beating cardiomyocytes. (Kadari et al. 2015, Laflamme et al. 2007, Sharma et al. 2015, Tan et al. 2016, Weng et al. 2014, Yang et al. 2008). Additionally, the above studies demonstrate that there is high line-to-line variability when differentiating stem cells into cardiomyocytes. Our Lenti- and Sendai-iPS differentiations provide additional supporting evidence in confirmation of this phenomenon in NHPs. Taken together, our data from Rhesus macaque, provide additional complementary evidence that cardiomyocytes can be efficiently differentiated in high purity from multiple human and non-human primate ES and iPS cells with the caveat that individual 
cell lines must be optimized to current differentiation protocols. To further test the applicability for cardiac repair, Rhesus iPS cell derived cardiomyocytes were used in the generation of engineered heart muscle.

\subsection{EHM can be constructed from RhiPS cell-derived cardiomyocytes}

Current methods of cellular transplantation into infarcted regions of the heart are either by direct injection (intravenous, intracoronary, or intramyocardial) or application of patch like constructs. Incidentally, direct injection methods have been shown have low rates of cellular retention (75-90\% lose within 24 hours) due immediate leakage at the injection site or circulatory clearance of non-adherent cells (reviewed in Tian et al. 2015). Conversely, patch like constructs have been shown to increase cell retention and have additional therapeutic benefits (Eschenhagen et al. 2012, Feric and Radisic 2016). These engineered constructs have been shown to stably engraft to recipient hearts, provide paracrine support, and produce an improvement in ventricular function (Didie et al. 2013, Riegler et al. 2015, Weinberger et al. 2016, Wendel et al. 2015, Zhu et al. 2017, Zimmermann et al. 2006). These studies have been conducted with neonatal rat cardiomyocyte allografts, murine parthenogenetic stem cell derived cardiomyocyte allografts or human xenograft cardiomyocytes. Following successful differentiation of RhiPS cells into cardiomyocytes the next step was construction of functional Rhesus EHM for subsequent in vivo testing.

Lenti-iPS cell-derived cardiomyocytes were combined with hFF and Sendai-iPS cellderived cardiomyocytes were combined with Rhesus gingival fibroblasts in a collagen matrix to produce EHMs. After 28 days in culture (25 days under dynamic stretching) the beating syncytia in Lenti- and Sendai-EHM were similar (Lenti: $0.19 \pm$ $0.03 \mathrm{mN}, \mathrm{n}=23$; Sendai: $0.2 \pm 0.02 \mathrm{mN}, \mathrm{n}=27$ ). The cross-sectional area of Rhesus EHM was similar to the cross-sectional area previously recorded in human EHM $-0.5 \mathrm{~mm}^{2}$. Force of contraction in Rhesus EHM were similar to the forces developed by neonatal human myocardium heart, i.e., 0.3-0.4 $\mathrm{mN} / \mathrm{mm}^{2}$ (Wiegerinck et al. 2009) and $\sim 5 \%$ of the forces recorded in adult human myocardium, i.e., $20 \mathrm{mN} / \mathrm{mm}^{2}$ (Mulieri et al. 1992). This will have to be considered and forces further optimized to meet the specific in vivo demands. Here it is also important to note that the macaque heart $(40 \mathrm{~g})$ is roughly $10 \%$ of the human heart $(400 \mathrm{~g})$. Human EHM developed un- 
der a similar protocol as the Rhesus EHM in this study developed up to $6 \mathrm{mN} / \mathrm{mm}^{2}$ (Tiburcy et al. 2017). Additional refinements of the Rhesus protocol as to electromechanical stimulation may assist in achieving these values. For investigations on the smaller Rhesus macaque heart, this may not be necessary if allometric scaling would be acceptable.

\subsection{Rhesus macaque EHM appear less mature than human EHM}

Positive inotropy is the ability to stimulate an increase in the contractility of the myocardium. Pharmaceutical drug treatments for heart failure focus on induction of positive inotropic response in the adult heart to counteract the decrease in myocardial function in a failing heart (Slinker et al. 2000, Tamargo et al. 2009). Identifying the state of functional maturity in stem cell derived cardiomyocytes and their derivatives is investigated through responses to increasing concentrations of extracellular calcium, bolus stimulation with the $\beta$-adrenergic agonist isprenaline, and increasing electrical stimulation frequencies (force-frequency behavior). Maximal inotropy of Rhesus EHMs (Lenti- and Sendai) was achieved at $2-4 \mathrm{mmol} / \mathrm{L}$ calcium with an $\mathrm{EC}_{50}$ at 0.8 $\mathrm{mmol} / \mathrm{L}$, indicating a maturing of the calcium handling machinery. Positive inotropic effects to isoprenaline suggested the presence of physiologically active $\beta$-adrenergic signaling (Tiburcy et al. 2017). Investigations of calcium handling and inotropic responses in early human ESC derived cardiomyocytes (9-19 days after the onset of spontaneous contraction) have shown that immature stem cell derived cardiomyocytes possess proper calcium handling machinery however lack a $\beta$-adrenergic response found in mature adult myocardium responsible for contractility stimulation (Pillekamp et al. 2012). The greater increased response in Sendai EHMs may be due to the higher purity of cardiomyocytes used in their production, $91 \pm 3 \%$ for Sendai EHMs as compared to the $58 \pm 7 \%$ for Lenti-EHMs. This difference in cardiomyocyte input would result in Sendai EHMs being comprised of more cardiomyocytes that would mature into a more postnatal phenotype and respond to $\beta$-adrenergic stimulation. Interestingly, investigation of the force frequency relationship of the EHMs resulted in a lack of positive response from both Lenti- and Sendai-EHMs. This is in contrast to findings in an apparently more mature human EHM model at the same time point of 4 weeks in culture (Tiburcy et al. 2017). To further mature Rhesus EHM it may be imperative to pre-condition Rhesus EHM with electrical pacing during 
culture to reach an optimal degree of functional maturation. Adjustment to nearphysiological stimulation frequencies was shown previously to enhance cardiomyocyte maturation in a rat EHM model (Godier-Furnemont et al. 2015).

\section{4 iPS reprogramming by integrating vectors increases the likelihood of on- cogene expression}

One of biggest challenges in transplanting pluripotent stem cell based therapeutics is ensuring the safety of not delivering undifferentiated or incompletely differentiated pluripotent cells that retain the potential to form tumors (Forsberg and Hovatta 2012, Hong et al. 2013). Blin et al (2010) have demonstrated that a purified population of SSEA $^{+}$Rhesus cardiac progenitor cells directly injected into an infarcted Rhesus heart can differentiate into ventricular myocytes and reconstituting $20 \%$ of an infarct scar. Conversely, they also demonstrated that an unpurified population results in teratoma formation. El Khatib et al (2016) have shown that iPS tumorigenicity is caused by residual pluripotent stem cells and excessive c-MYC expression caused by lentiviral genome integration. The observation of high expression of c-MYC in Lenti-EHM compared to Sendai-iPS monolayer derived cardiomyocytes agrees with this finding.

It is believed that c-MYC regulates expression levels of $15 \%$ of all genes (Gearhart et al. 2007). Okita et al (2007) demonstrated that reactivation of the c-MYC transgene was responsible for approximately $20 \%$ of tumors developing in chimeras generated from iPS cells. c-MYC has also been shown to be induced in cardiac hypertrophy, where cell size increases not cell number. This effect of c-MYC is in contrast to its regulation of cell number rather than cell size in embryos (Zhong et al. 2006). It is unknown if the high expression of the MYC gene was causing increased iPS proliferation or increased cardiomyocyte size within the Lenti-EHM. Findings from (Martinez-Fernandez et al. 2009) demonstrate that exclusion of c-MYC from iPS reprogramming factors resulted in an increase in cardiogenic lineage fate of differentiated iPS when compared to differentiated iPS cells when c-MYC was included in the reprogramming factors. This data provides support to the speculation that the high expression of c-MYC in Lenti-EHM was causing a cardiogenic hindrance during differentiation as demonstrated by the low purity of $\alpha$-actinin positive cardiomyocytes. 
This would also support the observation of lower cardiomyocyte purities following differentiation when compared to Sendai iPS differentiated cardiomyocytes.

The pluripotency gene POU5F1 was also shown to have increase expression in Lenti-EHMs. The POU5F1 gene encodes for the OCT4 protein involved in the selfrenewal, proliferative and pluripotent capabilities of undifferentiated stem cells (Yin et al. 2015). OCT4 works in cooperation with SOX2 and Nanog to maintain the selfrenewal and pluripotency capacity in ES and iPS cells (reviewed in Zeineddine et al. 2014). During normal differentiation OCT4 is upregulated and directly involved in mesoderm linage fate and cardiac specification, followed by a diminishing expression in terminally differentiated cardiac cells (Zeineddine et al. 2006). Prior to generation of Lenti-EHM an average of $19.6 \pm 5.3 \%$ OCT4 positive cells $(n=5$; data from A. Krahn, Institute of Pharmacology and Toxicology) were produced by LentiiPS differentiations. Since both C-MYC and OCT4 were contained in the STEMCCA integrating reprogramming vector it is highly likely that SOX-2 and NANOG may also show high expression levels in Lenti-EHMs although this was not tested.

Due to the high expression of C-MYC and OCT4 following transplantation in NODSCID mice combined with data indicating $19.6 \pm 5.3 \%$ OCT4 positive cells $(n=5$; data from A. Krahn, Institute of Pharmacology and Toxicology) remaining following Lenti-iPS differentations it was concluded that Lenti-iPS may be tumorigenic in prolonged implantation studies. Despite not having observed tumors in a 4 week pilot study, it appears plausible to conclude that reprogramming via integrating vectors should not be a preferred method for generating stem cell sources for use in therapeutic applications.

\subsection{Encapsulation enhanced directed differentiation in Lenti-iPS cells}

Maintaining stem cells in an undifferentiated state requires the in vitro creation of the in vivo microenvironment that provides growth factors, cell-to-cell interactions and cell matrix adhesions (reveiwed in Moore and Lemischka 2006). This can be supplied through feeder layer cultures or synthetic matrices with growth factor supplementation (Jozefczuk et al. 2012, Lin and Talbot 2011). Conversely, differentiation of stem cells requires the removal of stem cells from this environment of self-renewal 
and pluripotency plus the time specific treatment with growth factors and small molecules (Tiburcy et al. 2017).

In our first attempt to differentiate Lenti-iPS cells, removal from the feeder layer culture and cultured in monolayers on Matrigel ${ }^{\circledR}$ resulted in spontaneous differentiation and were not receptive to the recently established and highly effective human stem cell directed differentiation protocols (Riegler et al. 2015, Tiburcy et al. 2017). It is unknown if this was due to the removal of stemness supporting factors excreted by the fibroblast feeder layer, or the reported high biological activity of the Matrigel ${ }^{\circledR}$ (Kleinman and Martin 2005). An alternative strategy was devised that employed the encapsulation of the Lenti-iPS cell in an alginate hydrogel. It has been shown that encapsulation within alginate hydrogels creates a niche environment for stem cells to not only remain in a pluripotent state and propagate, but also differentiate (Dixon et al. 2014, Kryukov et al. 2014, Serra et al. 2011, Sidhu et al. 2012, Siti-Ismail et al. 2008). Our data confirms these findings, as cell number did increase prior to differentiation. Additionally, we have shown that alginate encapsulation enables the successful differentation of Lenti-iPS cells into spontaneously beating cardiomyocytes, albeit with lower efficiency and purity than their Sendai counterparts.

Coincidently, in a T25 culture flask with a surface area of $25 \mathrm{~cm}^{2}$, our current human monolayer differentiation cultures are seeded at a density of 25,000 cell/ $\mathrm{cm}^{2}$. Encapsulating cells at a concentration of $2.0 \times 10^{6} \mathrm{cells} / \mathrm{ml}$ and culturing them in a freefloating suspension resulted in an average of 50,000 cells/bead or 1,250,000 cells in the same culture dish ( 25 beads/flask). Culture after alginate encapsulation during 4 days of culture before the start of directed differentiation in the presence of $10 \mu \mathrm{mol} / \mathrm{L}$ RI 4 resulted in an average cell increase of $28 \pm 19 \%$ ( $n=5$ beads/time point) in predifferentiation cell number. Furthermore, an additional adjustment to the differentiation protocol to three days of feeder free culture with $5 \mu \mathrm{M} \mathrm{RI}$ would result in an increase in cell number by $57 \pm 20 \%$ ( $n=5$ beads/time point). Despite having a significant increase in cell number at the 72-hour time point after encapsulation using 2 $\mathrm{x} 10^{\wedge} 6$ cells and $5 \mu \mathrm{mol} / \mathrm{LL} \mathrm{RI}$ it was determined that fitting the encapsulation procedure to the standard differentiation protocol with $10 \mu \mathrm{mol} / \mathrm{L} \mathrm{RI}$ as well as having a more stable cellular content would be more beneficial for the generation of cardio- 
myocytes. Interestingly, directed differentiation was possible after this 4- day encapsulation pre-culture period, suggesting that the microenvironment in the beads rendered the Lenti-iPS cells inducible for directed differentiation. Notably, encapsulation was not required with the Sendai-iPS cells suggesting these cells possess a more stable pluripotent state than in Lenti-iPS cells. The instability of the Lenti-iPS cells may be potentially due to the continuous expression of the genomically integrated pluripotency factors from lentiviral reprogramming which has been previously reported.

\subsection{RhpSC can be derived from unfertilized oocytes after superovulation}

Cardiomyocytes generated from MHC homozygous iPS cells have previously been shown to have decreased immunogenicity when transplanted into an allogeneic MHC matched Rhesus macaque (Kawamura et al. 2016, Shiba et al. 2016). Prior work from our group has shown that murine pSC derived EHMs transplanted into MHC matched and mismatched mice exhibit immunological acceptance (Didie et al. 2013). We hypothesized that a similar immunological acceptance of MHC haploidentical Rhesus pSC would further reduce the immunogenicity of differentiated cardiomyocytes when transplanted as an EHM. Therefore, generation of pSC lines was attempted with Rhesus monkeys scheduled for future EHM safety studies.

To test this hypothesis pSC lines must first be generated. The Rhesus Mamu homologs to the human leukocyte antigen are present on chromosome 6. Coincidently, these alleles are located on the long arm of the chromosome in Rhesus macaques where there is a higher likelihood of crossing over events occurring during meiosis I as opposed to being located on the short arm of the chromosome in humans. Thus, generating a heterozygous cell line through retention of the second polar body may not be as beneficial in future Rhesus transplantation models as would be in human application. Therefore, attention should be given to the generation of homozygous parthenote cell line.

Generation of pSCs requires the activation of MII oocytes through chemical agents that mimic the fusion of PLC- $\zeta$ with the IP3R. Fusion of PLC- $\zeta$ with the IP3R initiates calcium oscillations in MII oocytes resulting in resumption of MII arrest (Saunders et 
al. 2002, Swann and Yu 2008). MIl arrest is caused by a cytostatic factor (CSF) regulated by cyclin B1 (Winston 1997). Successful generation of pSC requires the manipulation of the cyclin B1 equilibrium to produce either heterozygous or homozygous pSC.

In our attempts to produce pSC either 6DMAP or puromycin were used following activation by lonomycin to manipulate cyclin B1 for either extrusion or retention of the $2^{\text {nd }}$ PB. Extrusion of the second polar body requires the proper formation of the meiotic spindle. Proper spindle formation requires the degradation of Cyclin B1 causing a decrease in CSF and the resumption of MII. The mode of action of 6DMAP is through the stabilization of cyclin $\mathrm{B} 1$ following $\mathrm{Ca}^{2+}$ activation of the MII oocyte (Bodart et al. 1999) so that it cannot be degraded thus keeping the spindle fibers from properly forming and extruding the second polar body. Therefore, use of 6DMAP will produce a heterozygous pSC due to the retention of the second polar body followed by chromatid replication returning the haploid cell to a diploid state.

Conversely, the use of puromycin after oocyte activation will result in the formation of a homozygous pSC. Puromycin's mode of action is through inhibition of protein synthesis thus increasing the degradation of Cyclin B1 resulting in the decrease of CSF that leads to the cessation of MII arrest. Resumption of MII enables meiotic spindle formation (Homer 2013, Polański et al. 2012) and extrusion of the $2^{\text {nd }} P B$ to proceed as would occur during fertilization. Following $2^{\text {nd }} \mathrm{PB}$ extrusion, spontaneous replication of the single chromatid occurs returning the haploid cell to a stable diploid state (reviewed in Daughtry and Mitalipov 2014).

33 parthenogenetic blastomeres, 9 from 6DMAP treatment and 24 from puromycin treatment, were isolated from activated oocytes and placed into feeder layer cultures. Two of these transferred blastomeres, from the third ovulation cycle, demonstrated cellular outgrowths. Previous derivation of pSC from the Cynomolgus fascicularis monkey by Vrana et al (2003) resulted in one line (Cyno-1) being successfully generated. The Cyno-1 line was the result of 4 ICMs being plated from a total of 28 activated MII occytes obtained from resected ovaries. We could obtain blastomeric outgrowths from 2 separate monkeys obtained from a total of 9 plated blastomeres 
out of 22 activated Mll oocytes (from 5 monkeys) following ovariectomy. This is in comparison to the 20 plated blastomers from 27 activated MII oocytes following follicle aspiration that gave no outgrowths. These combined data indicate that the most optimal path of pSC line derivation is through isolation of oocytes from whole ovaries.

Incidentally, derivation of a Rhesus macaque haploidentical stem cell line was not completed due to the blastomeres not stabilizing in feeder culture for propagation. This is likely due to one of two factors (or both): (1) the inactivated hFF feeder layer did not properly support the outgrowth of cells despite successful human pSC culture being derived on hFF and/or (2) the culture medium used (Revazova et al. 2007) was not optimal for the propagation of Rhesus pSC as it is for human pSC. We believe that use of inactive mouse embryonic fibroblast feeder cultures will properly support the derivation of the pSC Rhesus macaque and will be utilized in future experiments. 


\subsection{Summary and outlook}

In conclusion, this dissertation has collectively provided evidence that RhiPS cells from integrating and non-integrating reprogramming methods can be successfully differentiated into functional cardiomyocytes. The efficiency and purity of these differentiations is comparable to other non-human and human primate stem cell based cardiomyocyte differentiations. Furthermore, these cardiomyocytes can be used to generate force producing EHM constructs similar to human EHMs generated in the same fashion, albeit with a less mature functional phenotype. Moreover, we generated two independent Rhesus macaque parthenogenetic stem cell lines from unfertilized oocytes. Experience and knowledge gained thus far in the derivation of pSC cells will enable us to establish stable cell lines soon.

We acknowledge that scaling of the differentiation protocol to increase the yield of cardiomyocyte production to reach the billions of cardiomyocytes required for in vivo EHM transplantation studies, is still a work in progress. However, with the data provided by the encapsulation experiments, we envision large scale culture and differentiation are possible in bioreactors. Further critical experiments need to be performed to develop methodologies for increasing the level of physiological maturity of Rhesus EHMs. These findings serve as a stable foundation for the translation of EHM constructs from small animal proof of concept and principle into safety and efficacy investigations utilizing the Rhesus macaque as a surrogate for pre-clinical human studies. 


\section{Bibliography}

1. Agarwal P, Zhao S, Bielecki P, Rao W, Choi JK, Zhao Y, Yu J, Zhang W, He $X$ (2013) One-step microfluidic generation of pre-hatching embryo-like core-shell microcapsules for miniaturized 3D culture of pluripotent stem cells. Lab Chip. 13:4525-33.

2. Agnetti G, Piepoli MF, Siniscalchi G, Nicolini F (2015) New Insights in the Diagnosis and Treatment of Heart Failure. Biomed Res Int. 2015:265260.

3. Averdam A, Kuhl H, Sontag M, Becker T, Hughes AL, Reinhardt R, Walter L (2007) Genomics and diversity of the common marmoset monkey NK complex. $J$ Immunol. 178:7151-61.

4. Bel A, Planat-Bernard V, Saito A, Bonnevie L, Bellamy V, Sabbah L, Bellabas L, Brinon B, Vanneaux V, Pradeau P, Peyrard S, Larghero J, Pouly J, Binder P, Garcia S, Shimizu T, Sawa Y, Okano T, Bruneval P, Desnos M, Hagege AA, Casteilla L, Puceat M, Menasche P (2010) Composite cell sheets: a further step toward safe and effective myocardial regeneration by cardiac progenitors derived from embryonic stem cells. Circulation. 122:S118-23.

5. Bjugstad KB, Teng YD, Redmond DE, Jr., Elsworth JD, Roth RH, Cornelius SK, Snyder EY, Sladek JR, Jr. (2008) Human neural stem cells migrate along the nigrostriatal pathway in a primate model of Parkinson's disease. Exp Neurol. 211:362-9.

6. Blin G, Nury D, Stefanovic S, Neri T, Guillevic O, Brinon B, Bellamy V, Rucker-Martin C, Barbry P, Bel A, Bruneval P, Cowan C, Pouly J, Mitalipov S, Gouadon E, Binder P, Hagege A, Desnos M, Renaud JF, Menasche P, Puceat M (2010) A purified population of multipotent cardiovascular progenitors derived from primate pluripotent stem cells engrafts in postmyocardial infarcted nonhuman primates. J Clin Invest. 120:1125-39.

7. Blom AS, Mukherjee R, Pilla JJ, Lowry AS, Yarbrough WM, Mingoia JT, Hendrick JW, Stroud RE, McLean JE, Affuso J, Gorman RC, Gorman JH, 3rd, Acker 
MA, Spinale FG (2005) Cardiac support device modifies left ventricular geometry and myocardial structure after myocardial infarction. Circulation. 112:1274-83.

8. Boatman DE. In Vitro growth of non-human primate pre- and periimplantation embryos. In: B. D. Bavister, ed. The Mammalian Preimplantation Embryo: regulation of Growth and Differentiation in Vitro: Springer Science \& Business Media; 1987.

9. Bodart JF, Bechard D, Bertout M, Gannon J, Rousseau A, Vilain JP, Flament $S$ (1999) Activation of Xenopus eggs by the kinase inhibitor 6-DMAP suggests a differential regulation of cyclin B and p39(mos) proteolysis. Exp Cell Res. 253:41321.

10. Braude $\mathrm{P}$, Bolton V, Moore S (1988) Human gene expression first occurs between the four- and eight-cell stages of preimplantation development. Nature. 332:459-61.

11. Brewer M, Baze W, Hill L, Utzinger U, Wharton JT, Follen M, Khan-Dawood F, Satterfield W (2001) Rhesus macaque model for ovarian cancer chemoprevention. Comp Med. 51:424-9.

12. Bui AL, Horwich TB, Fonarow GC (2011) Epidemiology and risk profile of heart failure. Nat Rev Cardiol. 8:30-41.

13. Burridge PW, Anderson D, Priddle H, Barbadillo Munoz MD, Chamberlain S, Allegrucci C, Young LE, Denning C (2007) Improved human embryonic stem cell embryoid body homogeneity and cardiomyocyte differentiation from a novel V-96 plate aggregation system highlights interline variability. Stem Cells. 25:929-38.

14. Burridge PW, Thompson S, Millrod MA, Weinberg S, Yuan X, Peters A, Mahairaki V, Koliatsos VE, Tung L, Zambidis ET (2011) A Universal System for Highly Efficient Cardiac Differentiation of Human Induced Pluripotent Stem Cells That Eliminates Interline Variability. PLOS ONE. 6:e18293. 
15. Burridge PW, Zambidis ET (2013) Highly efficient directed differentiation of human induced pluripotent stem cells into cardiomyocytes. Methods Mol Biol. 997:149-61.

16. Camelliti P, Borg TK, Kohl P (2005) Structural and functional characterisation of cardiac fibroblasts. Cardiovasc Res. 65:40-51.

17. Carlsson HE, Schapiro SJ, Farah I, Hau J (2004) Use of primates in research: a global overview. Am J Primatol. 63:225-37.

18. Chan AW, Cheng PH, Neumann A, Yang JJ (2010) Reprogramming Huntington monkey skin cells into pluripotent stem cells. Cell Reprogram. 12:509-17.

19. Chason RJ, Csokmay J, Segars JH, DeCherney AH, Armant DR (2011) Environmental and epigenetic effects upon preimplantation embryo metabolism and development. Trends Endocrinol Metab. 22:412-20.

20. Chen H, Hattori F, Murata M, Li W, Yuasa S, Onizuka T, Shimoji K, Ohno Y, Sasaki E, Kimura K, Hakuno D, Sano M, Makino S, Ogawa S, Fukuda K (2008) Common marmoset embryonic stem cell can differentiate into cardiomyocytes. Biochem Biophys Res Commun. 369:801-6.

21. Chen VC, Ye J, Shukla P, Hua G, Chen D, Lin Z, Liu JC, Chai J, Gold J, Wu J, Hsu D, Couture LA (2015) Development of a scalable suspension culture for cardiac differentiation from human pluripotent stem cells. Stem Cell Res. 15:365-75.

22. Chen Z, Liu Z, Huang J, Amano T, Li C, Cao S, Wu C, Liu B, Zhou L, Carter MG, Keefe DL, Yang X, Liu L (2009) Birth of parthenote mice directly from parthenogenetic embryonic stem cells. Stem Cells. 27:2136-45.

23. Chong JJ, Yang X, Don CW, Minami E, Liu YW, Weyers JJ, Mahoney WM, Van Biber B, Cook SM, Palpant NJ, Gantz JA, Fugate JA, Muskheli V, Gough GM, Vogel KW, Astley CA, Hotchkiss CE, Baldessari A, Pabon L, Reinecke H, Gill EA, 
Nelson V, Kiem HP, Laflamme MA, Murry CE (2014) Human embryonic-stem-cellderived cardiomyocytes regenerate non-human primate hearts. Nature. 510:273-7.

24. Coward K, Ponting CP, Chang HY, Hibbitt O, Savolainen P, Jones KT, Parrington J (2005) Phospholipase Czeta, the trigger of egg activation in mammals, is present in a non-mammalian species. Reproduction. 130:157-63.

25. Cox LJ, Larman MG, Saunders CM, Hashimoto K, Swann K, Lai FA (2002) Sperm phospholipase Czeta from humans and cynomolgus monkeys triggers $\mathrm{Ca2+}$ oscillations, activation and development of mouse oocytes. Reproduction. 124:61123.

26. Cui XS, Li XY, Kim NH (2007) Global gene transcription patterns in in vitrocultured fertilized embryos and diploid and haploid murine parthenotes. Biochem Biophys Res Commun. 352:709-15.

27. Dahlmann J, Krause A, Moller L, Kensah G, Mowes M, Diekmann A, Martin U, Kirschning A, Gruh I, Drager G (2013) Fully defined in situ cross-linkable alginate and hyaluronic acid hydrogels for myocardial tissue engineering. Biomaterials. 34:940-51.

28. Daughtry B, Mitalipov S (2014) Concise review: parthenote stem cells for regenerative medicine: genetic, epigenetic, and developmental features. Stem Cells Trans/ Med. 3:290-8.

29. Dayan V, Sotelo V, Delfina V, Delgado N, Rodriguez C, Suanes C, Langhain M, Ferrando R, Keating A, Benech A, Tourino C (2016) Human Mesenchymal Stromal Cells Improve Cardiac Perfusion in an Ovine Immunocompetent Animal Model. J Invest Surg. 29:218-25.

30. Daza-Vamenta R, Glusman G, Rowen L, Guthrie B, Geraghty DE (2004) Genetic divergence of the rhesus macaque major histocompatibility complex. Genome Res. 14:1501-15. 
31. de Fried EP, Ross P, Zang G, Divita A, Cunniff K, Denaday F, Salamone D, Kiessling A, Cibelli J (2008) Human parthenogenetic blastocysts derived from noninseminated cryopreserved human oocytes. Fertil Steril. 89:943-7.

32. Debowski K, Warthemann R, Lentes J, Salinas-Riester G, Dressel R, Langenstroth D, Gromoll J, Sasaki E, Behr R (2015) Non-viral generation of marmoset monkey iPS cells by a six-factor-in-one-vector approach. PLOS One. 10:e0118424.

33. Debowski K, Drummer C, Lentes J, Cors M, Dressel R, Lingner T, SalinasRiester G, Fuchs S, Sasaki E, Behr R (2016) The transcriptomes of novel marmoset monkey embryonic stem cell lines reflect distinct genomic features. Sci Rep. 6:29122.

34. Deleidi M, Hargus G, Hallett P, Osborn T, Isacson O (2011) Development of histocompatible primate-induced pluripotent stem cells for neural transplantation. Stem Cells. 29:1052-63.

35. Der Sarkissian S, Levesque T, Noiseux N (2017) Optimizing stem cells for cardiac repair: Current status and new frontiers in regenerative cardiology. World $\mathrm{J}$ Stem Cells. 9:9-25.

36. Didie M, Christalla P, Rubart M, Muppala V, Doker S, Unsold B, El-Armouche A, Rau T, Eschenhagen T, Schwoerer AP, Ehmke H, Schumacher U, Fuchs S, Lange C, Becker A, Tao W, Scherschel JA, Soonpaa MH, Yang T, Lin Q, Zenke M, Han DW, Scholer HR, Rudolph C, Steinemann D, Schlegelberger B, Kattman S, Witty A, Keller G, Field LJ, Zimmermann WH (2013) Parthenogenetic stem cells for tissue-engineered heart repair. J Clin Invest. 123:1285-98.

37. Dighe V, Clepper L, Pedersen D, Byrne J, Ferguson B, Gokhale S, Penedo MCT, Wolf D, Mitalipov S (2008) Heterozygous Embryonic Stem Cell Lines Derived from Nonhuman Primate Parthenotes. Stem Cells. 26:756-766. 
38. Dixon JE, Shah DA, Rogers C, Hall S, Weston N, Parmenter CD, McNally D, Denning C, Shakesheff KM (2014) Combined hydrogels that switch human pluripotent stem cells from self-renewal to differentiation. Proc Natl Acad Sci U S A. 111:5580-5.

39. Doetschman T, Williams P, Maeda N (1988) Establishment of hamster blastocyst-derived embryonic stem (ES) cells. Dev Biol. 127:224-7.

40. Egusa H, Okita K, Kayashima H, Yu G, Fukuyasu S, Saeki M, Matsumoto T, Yamanaka S, Yatani H (2010) Gingival fibroblasts as a promising source of induced pluripotent stem cells. PLoS One. 5:e12743.

41. El Khatib MM, Ohmine S, Jacobus EJ, Tonne JM, Morsy SG, Holditch SJ, Schreiber CA, Uetsuka K, Fusaki N, Wigle DA, Terzic A, Kudva YC, Ikeda Y (2016) Tumor-Free Transplantation of Patient-Derived Induced Pluripotent Stem Cell Progeny for Customized Islet Regeneration. Stem Cells Trans/ Med. 5:694-702.

42. Eschenhagen T, Fink $\mathrm{C}$, Remmers $\mathrm{U}$, Scholz $\mathrm{H}$, Wattchow J, Weil J, Zimmermann W, Dohmen HH, Schafer H, Bishopric N, Wakatsuki T, Elson EL (1997) Three-dimensional reconstitution of embryonic cardiomyocytes in a collagen matrix: a new heart muscle model system. Faseb J. 11:683-94.

43. Eschenhagen T, Eder A, Vollert I, Hansen A (2012) Physiological aspects of cardiac tissue engineering. Am J Physiol Heart Circ Physiol. 303:H133-43.

44. Evans MJ, Kaufman MH (1981) Establishment in culture of pluripotential cells from mouse embryos. Nature. 292:154-6.

45. Fang R, Liu K, Zhao Y, Li H, Zhu D, Du Y, Xiang C, Li X, Liu H, Miao Z, Zhang X, Shi Y, Yang W, Xu J, Deng H (2014) Generation of naive induced pluripotent stem cells from rhesus monkey fibroblasts. Cell Stem Cell. 15:488-96.

46. Farahmand P, Lai TY, Weisel RD, Fazel S, Yau T, Menasche P, Li RK (2008) Skeletal myoblasts preserve remote matrix architecture and global function when 
implanted early or late after coronary ligation into infarcted or remote myocardium. Circulation. 118:S130-7.

47. Feric NT, Radisic M (2016) Strategies and Challenges to Myocardial Replacement Therapy. Stem Cells Transl Med. 5:410-6.

48. Flanagan TC, Sachweh JS, Frese J, Schnoring H, Gronloh N, Koch S, Tolba $\mathrm{RH}$, Schmitz-Rode T, Jockenhoevel S (2009) In vivo remodeling and structural characterization of fibrin-based tissue-engineered heart valves in the adult sheep model. Tissue Eng Part A. 15:2965-76.

49. Forsberg M, Hovatta O (2012) Challenges for the Therapeutic use of Pluripotent Stem Derived Cells. Front Physiol. 3:19.

50. Fuegemann CJ, Samraj AK, Walsh S, Fleischmann BK, Jovinge S, Breitbach $M(2010)$ Differentiation of mouse embryonic stem cells into cardiomyocytes via the hanging-drop and mass culture methods. Curr Protoc Stem Cell Biol. Chapter 1:Unit $1 \mathrm{~F} 11$.

51. Gandolfi F, Vanelli A, Pennarossa G, Rahaman M, Acocella F, Brevini TA (2011) Large animal models for cardiac stem cell therapies. Theriogenology. 75:1416-25.

52. Gardner MB, Luciw PA (2008) Macaque models of human infectious disease. ILAR J. 49:220-55.

53. Gearhart J, Pashos EE, Prasad MK (2007) Pluripotency redux--advances in stem-cell research. N Engl J Med. 357:1469-72.

54. Genain CP, Lee-Parritz D, Nguyen MH, Massacesi L, Joshi N, Ferrante R, Hoffman K, Moseley M, Letvin NL, Hauser SL (1994) In healthy primates, circulating autoreactive T cells mediate autoimmune disease. J Clin Invest. 94:1339-45. 
55. Gepstein L (2002) Derivation and potential applications of human embryonic stem cells. Circ Res. 91:866-76.

56. Giovagnoli S, Mancuso F, Vannini S, Calvitti M, Piroddi M, Pietrella D, Arato I, Falabella G, Galli F, Moretti M, Neri LM, Bodo M, Capitani S, Cameron DF, Ricci M, Luca G, Calafiore R (2014) Microparticle-loaded neonatal porcine Sertoli cells for cell-based therapeutic and drug delivery system. J Control Release. 192:249-61.

57. Godier-Furnemont AF, Tiburcy M, Wagner E, Dewenter M, Lammle S, ElArmouche A, Lehnart SE, Vunjak-Novakovic G, Zimmermann WH (2015) Physiologic force-frequency response in engineered heart muscle by electromechanical stimulation. Biomaterials. 60:82-91.

58. Goldthwaite J, Charles A. (2006) Mending a Broken Heart: Stem Cells and Cardiac Repair.

59. Gorman JH, 3rd, Gorman RC, Plappert T, Jackson BM, Hiramatsu Y, St JohnSutton MG, Edmunds LH, Jr. (1998) Infarct size and location determine development of mitral regurgitation in the sheep model. $J$ Thorac Cardiovasc Surg. 115:615-22.

60. Graves KH, Moreadith RW (1993) Derivation and characterization of putative pluripotential embryonic stem cells from preimplantation rabbit embryos. Mol Reprod Dev. 36:424-33.

61. Hao M, Wang R, Wang W (2017) Cell Therapies in Cardiomyopathy: Current Status of Clinical Trials. Anal Cell Pathol (Amst). 2017:9404057.

62. Harding J, Roberts RM, Mirochnitchenko O (2013) Large animal models for stem cell therapy. Stem Cell Res Ther. 4:23.

63. Harness JV, Turovets NA, Seiler MJ, Nistor G, Altun G, Agapova LS, Ferguson D, Laurent LC, Loring JF, Keirstead HS (2011) Equivalence of conventionally-derived and parthenote-derived human embryonic stem cells. PLOS One. 6:e14499. 
64. Hatoya S, Torii R, Kondo Y, Okuno T, Kobayashi K, Wijewardana V, Kawate N, Tamada H, Sawada T, Kumagai D, Sugiura K, Inaba T (2006) Isolation and characterization of embryonic stem-like cells from canine blastocysts. Mol Reprod Dev. 73:298-305.

65. Homer H. Getting into and out of oocyte maturation. In: A. Trounson, R. G. Gosden and U. Eichenlaub-Ritter, eds. Biology and pathology of the oocyte : role in fertility, medicine and nuclear reprogramming. Second edition. ed. Cambridge, United Kingdom ; New York: Cambridge University Press; 2013: xiv, 454 pages.

66. Honda A, Hirose M, Hatori M, Matoba S, Miyoshi H, Inoue K, Ogura A (2010) Generation of induced pluripotent stem cells in rabbits: potential experimental models for human regenerative medicine. J Biol Chem. 285:31362-9.

67. Hong SG, Dunbar CE, Winkler T (2013) Assessing the risks of genotoxicity in the therapeutic development of induced pluripotent stem cells. Mol Ther. 21:272-81.

68. Honge JL, Funder JA, Jensen H, Dohmen PM, Konertz WF, Hasenkam JM (2010) Recellularization of decellularized mitral heart valves in juvenile pigs. $J$ Heart Valve Dis. 19:584-92.

69. Horton R, Wilming L, Rand V, Lovering RC, Bruford EA, Khodiyar VK, Lush MJ, Povey S, Talbot CC, Jr., Wright MW, Wain HM, Trowsdale J, Ziegler A, Beck S (2004) Gene map of the extended human MHC. Nat Rev Genet. 5:889-99.

70. Hou DR, Jin Y, Nie XW, Zhang ML, Ta N, Zhao LH, Yang N, Chen Y, Wu ZQ, Jiang HB, Li YR, Sun QY, Dai YF, Li RF (2016) Derivation of Porcine Embryonic Stem-Like Cells from In Vitro-Produced Blastocyst-Stage Embryos. Sci Rep. 6:25838.

71. Huber I, Walter L, Wimmer R, Pasantes JJ, Gunther E, Schempp W (2003) Cytogenetic mapping and orientation of the rhesus macaque MHC. Cytogenet Genome Res. 103:144-9. 
72. Hudson JE, Zimmermann WH (2011) Tuning Wnt-signaling to enhance cardiomyogenesis in human embryonic and induced pluripotent stem cells. $\mathrm{J} \mathrm{Mol}$ Cell Cardiol. 51:277-9.

73. Hyun I (2010) The bioethics of stem cell research and therapy. J Clin Invest. 120:71-5.

74. Jackson BM, Gorman JH, Moainie SL, Guy TS, Narula N, Narula J, JohnSutton MG, Edmunds LH, Jr., Gorman RC (2002) Extension of borderzone myocardium in postinfarction dilated cardiomyopathy. J Am Coll Cardiol. 40:1160-7; discussion 1168-71.

75. Jing D, Parikh A, Tzanakakis ES (2010) Cardiac cell generation from encapsulated embryonic stem cells in static and scalable culture systems. Cell Transplant. 19:1397-412.

76. Jozefczuk J, Drews K, Adjaye J (2012) Preparation of mouse embryonic fibroblast cells suitable for culturing human embryonic and induced pluripotent stem cells. $J$ Vis Exp.

77. Jugdutt $\mathrm{BI}$, Menon V (2004) Valsartan-induced cardioprotection involves angiotensin II type 2 receptor upregulation in dog and rat models of in vivo reperfused myocardial infarction. J Card Fail. 10:74-82.

78. Kadari A, Mekala S, Wagner N, Malan D, Koth J, Doll K, Stappert L, Eckert D, Peitz M, Matthes J, Sasse P, Herzig S, Brustle O, Ergun S, Edenhofer F (2015) Robust Generation of Cardiomyocytes from Human iPS Cells Requires Precise Modulation of BMP and WNT Signaling. Stem Cell Rev. 11:560-9.

79. Kattman SJ, Witty AD, Gagliardi M, Dubois NC, Niapour M, Hotta A, Ellis J, Keller G (2011) Stage-specific optimization of activin/nodal and BMP signaling promotes cardiac differentiation of mouse and human pluripotent stem cell lines. Cell Stem Cell. 8:228-40. 
80. Kawamura T, Miyagawa S, Fukushima S, Maeda A, Kashiyama N, Kawamura A, Miki K, Okita K, Yoshida Y, Shiina T, Ogasawara K, Miyagawa S, Toda K, Okuyama H, Sawa Y (2016) Cardiomyocytes Derived from MHC-Homozygous Induced Pluripotent Stem Cells Exhibit Reduced Allogeneic Immunogenicity in MHCMatched Non-human Primates. Stem Cell Reports. 6:312-20.

81. Kehat I, Kenyagin-Karsenti D, Snir M, Segev H, Amit M, Gepstein A, Livne E, Binah O, Itskovitz-Eldor J, Gepstein L (2001) Human embryonic stem cells can differentiate into myocytes with structural and functional properties of cardiomyocytes. The Journal of Clinical Investigation. 108:407-414.

82. Kempf $\mathrm{H}$, Olmer R, Kropp C, Ruckert M, Jara-Avaca M, Robles-Diaz D, Franke A, Elliott DA, Wojciechowski D, Fischer M, Roa Lara A, Kensah G, Gruh I, Haverich A, Martin U, Zweigerdt R (2014) Controlling expansion and cardiomyogenic differentiation of human pluripotent stem cells in scalable suspension culture. Stem Cell Reports. 3:1132-46.

83. Kharche SD, Goel AK, Jindal SK, Ranjan R, Rout PK, Agarwal SK, Goel P, Saraswat S, Vijh RK, Malakar D, Bag S, Sarkhel B, Bhanja SK (2014) Development of parthenote following in vivo transfer of embryos in Capra hircus. In Vitro Cell Dev Biol Anim. 50:893-8.

84. Kiem HP, Sellers S, Thomasson B, Morris JC, Tisdale JF, Horn PA, Hematti P, Adler R, Kuramoto K, Calmels B, Bonifacino A, Hu J, von Kalle C, Schmidt M, Sorrentino B, Nienhuis A, Blau CA, Andrews RG, Donahue RE, Dunbar CE (2004) Long-term clinical and molecular follow-up of large animals receiving retrovirally transduced stem and progenitor cells: no progression to clonal hematopoiesis or leukemia. Mol Ther. 9:389-95.

85. Kim K, Lerou P, Yabuuchi A, Lengerke C, Ng K, West J, Kirby A, Daly MJ, Daley GQ (2007a) Histocompatible embryonic stem cells by parthenogenesis. Science. 315:482-6. 
86. Kim K, Ng K, Rugg-Gunn PJ, Shieh JH, Kirak O, Jaenisch R, Wakayama T, Moore MA, Pedersen RA, Daley GQ (2007b) Recombination signatures distinguish embryonic stem cells derived by parthenogenesis and somatic cell nuclear transfer. Cell Stem Cell. 1:346-52.

87. Kleinman HK, Martin GR (2005) Matrigel: basement membrane matrix with biological activity. Semin Cancer Biol. 15:378-86.

88. Klug MG, Soonpaa MH, Koh GY, Field LJ (1996) Genetically selected cardiomyocytes from differentiating embronic stem cells form stable intracardiac grafts. J Clin Invest. 98:216-24.

89. Koh S, Piedrahita JA (2015) Generation of Induced Pluripotent Stem Cells (iPSCs) from Adult Canine Fibroblasts. Methods Mol Biol. 1330:69-78.

90. Kryukov O, Ruvinov E, Cohen S (2014) Three-dimensional perfusion cultivation of human cardiac-derived progenitors facilitates their expansion while maintaining progenitor state. Tissue Eng Part C Methods. 20:886-94.

91. Laflamme MA, Murry CE (2005) Regenerating the heart. Nat Biotechnol. 23:845-56.

92. Laflamme MA, Chen KY, Naumova AV, Muskheli V, Fugate JA, Dupras SK, Reinecke H, Xu C, Hassanipour M, Police S, O'Sullivan C, Collins L, Chen Y, Minami E, Gill EA, Ueno S, Yuan C, Gold J, Murry CE (2007) Cardiomyocytes derived from human embryonic stem cells in pro-survival factors enhance function of infarcted rat hearts. Nat Biotechnol. 25:1015-24.

93. Laflamme MA, Murry CE (2011) Heart regeneration. Nature. 473:326-35.

94. Lee YS, VandeVoort CA, Gaughan JP, Midic U, Obradovic Z, Latham KE (2011) Extensive effects of in vitro oocyte maturation on rhesus monkey cumulus cell transcriptome. Am J Physiol Endocrinol Metab. 301:E196-209. 
95. Leschik J, Stefanovic S, Brinon B, Puceat M (2008) Cardiac commitment of primate embryonic stem cells. Nat Protoc. 3:1381-7.

96. Levit RD, Landazuri N, Phelps EA, Brown ME, Garcia AJ, Davis ME, Joseph G, Long R, Safley SA, Suever JD, Lyle AN, Weber CJ, Taylor WR (2013) Cellular encapsulation enhances cardiac repair. J Am Heart Assoc. 2:e000367.

97. Li P, Tong C, Mehrian-Shai R, Jia L, Wu N, Yan Y, Maxson RE, Schulze EN, Song H, Hsieh CL, Pera MF, Ying QL (2008) Germline competent embryonic stem cells derived from rat blastocysts. Cell. 135:1299-310.

98. Lian X, Hsiao C, Wilson G, Zhu K, Hazeltine LB, Azarin SM, Raval KK, Zhang J, Kamp TJ, Palecek SP (2012) Robust cardiomyocyte differentiation from human pluripotent stem cells via temporal modulation of canonical Wnt signaling. Proc Natl Acad Sci U S A. 109:E1848-57.

99. Lian X, Zhang J, Azarin SM, Zhu K, Hazeltine LB, Bao X, Hsiao C, Kamp TJ, Palecek SP (2013) Directed cardiomyocyte differentiation from human pluripotent stem cells by modulating Wnt/beta-catenin signaling under fully defined conditions. Nat Protoc. 8:162-75.

100. Liao J, Cui C, Chen S, Ren J, Chen J, Gao Y, Li H, Jia N, Cheng L, Xiao H, Xiao $L$ (2009) Generation of induced pluripotent stem cell lines from adult rat cells. Cell Stem Cell. 4:11-5.

101. Lin S, Talbot $P$ (2011) Methods for culturing mouse and human embryonic stem cells. Methods Mol Biol. 690:31-56.

102. Liu H, Zhu F, Yong J, Zhang P, Hou P, Li H, Jiang W, Cai J, Liu M, Cui K, Qu X, Xiang T, Lu D, Chi X, Gao G, Ji W, Ding M, Deng H (2008) Generation of induced pluripotent stem cells from adult rhesus monkey fibroblasts. Cell Stem Cell. 3:58790. 
103. Lozier JN, Metzger ME, Donahue RE, Morgan RA (1999) The rhesus macaque as an animal model for hemophilia B gene therapy. Blood. 93:1875-81.

104. Lu H, Xu X, Zhang M, Cao R, Brakenhielm E, Li C, Lin H, Yao G, Sun H, Qi L, Tang M, Dai H, Zhang Y, Su R, Bi Y, Zhang Y, Cao Y (2007) Combinatorial protein therapy of angiogenic and arteriogenic factors remarkably improves collaterogenesis and cardiac function in pigs. Proc Natl Acad Sci U S A. 104:12140-5.

105. Luca G, Cameron DF, Arato I, Mancuso F, Linden EH, Calvitti M, Falabella G, Szekeres K, Bodo M, Ricci G, Hansen BC, Calafiore R (2014) Xenograft of microencapsulated Sertoli cells for the cell therapy of type 2 diabetes mellitus in spontaneously diabetic nonhuman primates: preliminary data. Transplant Proc. 46:1999-2001.

106. Lundy SD, Zhu WZ, Regnier M, Laflamme MA (2013) Structural and functional maturation of cardiomyocytes derived from human pluripotent stem cells. Stem Cells Dev. 22:1991-2002.

107. Markovitz LJ, Savage EB, Ratcliffe MB, Bavaria JE, Kreiner G, lozzo RV, Hargrove WC, 3rd, Bogen DK, Edmunds LH, Jr. (1989) Large animal model of left ventricular aneurysm. Ann Thorac Surg. 48:838-45.

108. Marques MG, Nascimento AB, Gerger RP, Goncalves JS, Coutinho AR, Simoes R, Assumpcao ME, Visintin JA (2011) Effect of culture media on porcine embryos produced by in vitro fertilization or parthenogenetic activation after oocyte maturation with cycloheximide. Zygote. 19:331-7.

109. Martinez-Fernandez A, Nelson TJ, Yamada S, Reyes S, Alekseev AE, PerezTerzic C, Ikeda Y, Terzic A (2009) iPS programmed without c-MYC yield proficient cardiogenesis for functional heart chimerism. Circ Res. 105:648-56.

110. Mazo M, Gavira JJ, Abizanda G, Moreno C, Ecay M, Soriano M, Aranda P, Collantes M, Alegria E, Merino J, Penuelas I, Garcia Verdugo JM, Pelacho B, Prosper $F$ (2010) Transplantation of mesenchymal stem cells exerts a greater long- 
term effect than bone marrow mononuclear cells in a chronic myocardial infarction model in rat. Cell Transplant. 19:313-28.

111. McCall FC, Telukuntla KS, Karantalis V, Suncion VY, Heldman AW, Mushtaq M, Williams AR, Hare JM (2012) Myocardial infarction and intramyocardial injection models in swine. Nat Protoc. 7:1479-96.

112. Mitalipov SM, Nusser KD, Wolf DP (2001) Parthenogenetic activation of rhesus monkey oocytes and reconstructed embryos. Biol Reprod. 65:253-9.

113. Moore KA, Lemischka IR (2006) Stem cells and their niches. Science. 311:1880-5.

114. Moorman A, Webb S, Brown NA, Lamers W, Anderson RH (2003) DEVELOPMENT OF THE HEART: (1) FORMATION OF THE CARDIAC CHAMBERS AND ARTERIAL TRUNKS. Heart 2003 Jul; 89(7): 806-814. 89:806814.

115. Morin N, Jourdain VA, Di Paolo T (2014) Modeling dyskinesia in animal models of Parkinson disease. Exp Neurol. 256:105-16.

116. Mulieri LA, Leavitt BJ, Hasenfuss G, Allen PD, Alpert NR (1992) Contraction frequency dependence of twitch and diastolic tension in human dilated cardiomyopathy (tension-frequency relation in cardiomyopathy). Basic Res Cardiol. 87 Suppl 1:199-212.

117. Naito H, Melnychenko I, Didie M, Schneiderbanger K, Schubert $P$, Rosenkranz S, Eschenhagen T, Zimmermann WH (2006) Optimizing engineered heart tissue for therapeutic applications as surrogate heart muscle. Circulation. 114:172-8.

118. Nakatsuji N, Nakajima F, Tokunaga K (2008) HLA-haplotype banking and iPS cells. Nat Biotechnol. 26:739-40. 
119. Naturil-Alfonso C, Jimenez-Trigos E, Vicente JS, Marco-Jimenez F (2015) Effect of in vitro and in vivo conditions on development of parthenogenetic rabbit embryos after vitrification. Cryobiology. 71:91-6.

120. Navara CS, Hornecker J, Grow D, Chaudhari S, Hornsby PJ, Ichida JK, Eggan K, McCarrey JR (2013) Derivation of induced pluripotent stem cells from the baboon: a nonhuman primate model for preclinical testing of stem cell therapies. Cell Reprogram. 15:495-502.

121. Nichols SM, Gierbolini L, Gonzalez-Martinez JA, Bavister BD (2010) Effects of in vitro maturation and age on oocyte quality in the rhesus macaque Macaca mulatta. Fertil Steril. 93:1591-600.

122. Nicolini F, Piepoli MF, Agnetti G, Siniscalchi G (2015) Alternatives to Transplantation in the Treatment of Heart Failure: New Diagnostic and Therapeutic Insights. Biomed Res Int. 2015:278163.

123. Notarianni E, Galli C, Laurie S, Moor RM, Evans MJ (1991) Derivation of pluripotent, embryonic cell lines from the pig and sheep. J Reprod Fertil Suppl. 43:255-60.

124. Ogle BM, Bursac N, Domian I, Huang NF, Menasche P, Murry CE, Pruitt B, Radisic M, Wu JC, Wu SM, Zhang J, Zimmermann WH, Vunjak-Novakovic G (2016) Distilling complexity to advance cardiac tissue engineering. Sci Trans/ Med. 8:342ps13.

125. Okita K, Ichisaka T, Yamanaka S (2007) Generation of germline-competent induced pluripotent stem cells. Nature. 448:313-7.

126. Olivetti G, Melissari M, Capasso JM, Anversa P (1991) Cardiomyopathy of the aging human heart. Myocyte loss and reactive cellular hypertrophy. Circ Res. 68:1560-8. 
127. Olmer R, Martin U, Zweigerdt R (2010) Expansion and differentiation of human iPS and ES cells in stirred tank bioreactors. J Stem Cells Regen Med. 6:119.

128. Paredes Juarez GA, Spasojevic M, Faas MM, de Vos P (2014) Immunological and technical considerations in application of alginate-based microencapsulation systems. Front Bioeng Biotechnol. 2:26.

129. Phillips KA, Bales KL, Capitanio JP, Conley A, Czoty PW, t Hart BA, Hopkins WD, Hu SL, Miller LA, Nader MA, Nathanielsz PW, Rogers J, Shively CA, Voytko ML (2014) Why primate models matter. Am J Primatol. 76:801-27.

130. Pillekamp F, Haustein M, Khalil M, Emmelheinz M, Nazzal R, Adelmann R, Nguemo F, Rubenchyk O, Pfannkuche K, Matzkies M, Reppel M, Bloch W, Brockmeier K, Hescheler J (2012) Contractile properties of early human embryonic stem cell-derived cardiomyocytes: beta-adrenergic stimulation induces positive chronotropy and lusitropy but not inotropy. Stem Cells Dev. 21:2111-21.

131. Plews JR, Gu M, Longaker MT, Wu JC (2012) Large animal induced pluripotent stem cells as pre-clinical models for studying human disease. $J$ Cell Mol Med. 16:1196-202.

132. Polański Z, Homer H, Kubiak JZ. In: J. Z. Kubiak, ed. Mouse development : from oocyte to stem cells Berlin ; New York: Springer; 2012: viii, 738 p.

133. Prescott MJ (2010) Ethics of primate use. Advances in Science and Research. 5:11-22.

134. Przyklenk K, Vivaldi MT, Schoen FJ, Malcolm J, Arnold O, Kloner RA (1986) Salvage of ischaemic myocardium by reperfusion: importance of collateral blood flow and myocardial oxygen demand during occlusion. Cardiovasc Res. 20:403-14.

135. Qin X, Riegler J, Tiburcy M, Zhao X, Chour T, Ndoye B, Nguyen M, Adams J, Ameen M, Denney TS, Jr., Yang PC, Nguyen P, Zimmermann WH, Wu JC (2016) 
Magnetic Resonance Imaging of Cardiac Strain Pattern Following Transplantation of Human Tissue Engineered Heart Muscles. Circ Cardiovasc Imaging. 9.

136. Rajendran $P$, Rengarajan $T$, Thangavel J, Nishigaki $Y$, Sakthisekaran $D$, Sethi G, Nishigaki I (2013) The vascular endothelium and human diseases. Int J Biol Sci. 9:1057-69.

137. Reimer KA, Lowe JE, Rasmussen MM, Jennings RB (1977) The wavefront phenomenon of ischemic cell death. 1. Myocardial infarct size vs duration of coronary occlusion in dogs. Circulation. 56:786-94.

138. Reimer KA, Jennings RB (1979) The "wavefront phenomenon" of myocardial ischemic cell death. II. Transmural progression of necrosis within the framework of ischemic bed size (myocardium at risk) and collateral flow. Lab Invest. 40:633-44.

139. Revazova ES, Turovets NA, Kochetkova OD, Kindarova LB, Kuzmichev LN, Janus JD, Pryzhkova MV (2007) Patient-specific stem cell lines derived from human parthenogenetic blastocysts. Cloning Stem Cells. 9:432-49.

140. Revazova ES, Turovets NA, Kochetkova OD, Agapova LS, Sebastian JL, Pryzhkova MV, Smolnikova VI, Kuzmichev LN, Janus JD (2008) HLA homozygous stem cell lines derived from human parthenogenetic blastocysts. Cloning Stem Cells. 10:11-24.

141. Riegler J, Tiburcy M, Ebert A, Tzatzalos E, Raaz U, Abilez OJ, Shen Q, Kooreman NG, Neofytou E, Chen VC, Wang M, Meyer T, Tsao PS, Connolly AJ, Couture LA, Gold JD, Zimmermann WH, Wu JC (2015) Human Engineered Heart Muscles Engraft and Survive Long Term in a Rodent Myocardial Infarction Model. Circ Res. 117:720-30.

142. Rogers J, Gibbs RA (2014) Comparative primate genomics: emerging patterns of genome content and dynamics. Nat Rev Genet. 15:347-59. 
143. Rogers NT, Hobson E, Pickering S, Lai FA, Braude P, Swann K (2004) Phospholipase Czeta causes $\mathrm{Ca} 2+$ oscillations and parthenogenetic activation of human oocytes. Reproduction. 128:697-702.

144. Rosellini E, Cristallini C, Barbani N, Vozzi G, Giusti P (2009) Preparation and characterization of alginate/gelatin blend films for cardiac tissue engineering. $J$ Biomed Mater Res A. 91:447-53.

145. Ross PJ, Beyhan Z, lager AE, Yoon SY, Malcuit C, Schellander K, Fissore RA, Cibelli JB (2008) Parthenogenetic activation of bovine oocytes using bovine and murine phospholipase C zeta. BMC Dev Biol. 8:16.

146. Ruvinov E, Cohen S (2016) Alginate biomaterial for the treatment of myocardial infarction: Progress, translational strategies, and clinical outlook: From ocean algae to patient bedside. Adv Drug Deliv Rev. 96:54-76.

147. Sabbah HN, Stein PD, Kono T, Gheorghiade M, Levine TB, Jafri S, Hawkins ET, Goldstein S (1991) A canine model of chronic heart failure produced by multiple sequential coronary microembolizations. Am J Physiol. 260:H1379-84.

148. Sabbah HN, Sharov VG, Gupta RC, Mishra S, Rastogi S, Undrovinas Al, Chaudhry PA, Todor A, Mishima T, Tanhehco EJ, Suzuki G (2003) Reversal of chronic molecular and cellular abnormalities due to heart failure by passive mechanical ventricular containment. Circ Res. 93:1095-101.

149. Sagi I, Chia G, Golan-Lev T, Peretz M, Weissbein U, Sui L, Sauer MV, Yanuka O, Egli D, Benvenisty N (2016a) Derivation and differentiation of haploid human embryonic stem cells. Nature. 532:107-11.

150. Sagi I, Egli D, Benvenisty N (2016b) Identification and propagation of haploid human pluripotent stem cells. Nat Protoc. 11:2274-2286. 
151. Saito S, Strelchenko N, Niemann H (1992) Bovine embryonic stem cell-like cell lines cultured over several passages. Roux's Archives of Developmental Biology. 201:134-141.

152. Saunders CM, Larman MG, Parrington J, Cox LJ, Royse J, Blayney LM, Swann K, Lai FA (2002) PLC zeta: a sperm-specific trigger of $\mathrm{Ca}(2+)$ oscillations in eggs and embryo development. Development. 129:3533-44.

153. Schwanke K, Wunderlich S, Reppel M, Winkler ME, Matzkies M, Groos S, Itskovitz-Eldor J, Simon AR, Hescheler J, Haverich A, Martin U (2006) Generation and characterization of functional cardiomyocytes from rhesus monkey embryonic stem cells. Stem Cells. 24:1423-32.

154. Serra M, Correia C, Malpique R, Brito C, Jensen J, Bjorquist P, Carrondo MJ, Alves PM (2011) Microencapsulation technology: a powerful tool for integrating expansion and cryopreservation of human embryonic stem cells. PLoS One. 6:e23212.

155. Sharma A, Li G, Rajarajan K, Hamaguchi R, Burridge PW, Wu SM (2015) Derivation of highly purified cardiomyocytes from human induced pluripotent stem cells using small molecule-modulated differentiation and subsequent glucose starvation. J Vis Exp.

156. Shiba Y, Fernandes S, Zhu WZ, Filice D, Muskheli V, Kim J, Palpant NJ, Gantz J, Moyes KW, Reinecke H, Van Biber B, Dardas T, Mignone JL, Izawa A, Hanna R, Viswanathan M, Gold JD, Kotlikoff MI, Sarvazyan N, Kay MW, Murry CE, Laflamme MA (2012) Human ES-cell-derived cardiomyocytes electrically couple and suppress arrhythmias in injured hearts. Nature. 489:322-5.

157. Shiba $Y$, Gomibuchi $T$, Seto $T$, Wada $Y$, Ichimura $H$, Tanaka $Y$, Ogasawara $T$, Okada K, Shiba N, Sakamoto K, Ido D, Shiina T, Ohkura M, Nakai J, Uno N, Kazuki Y, Oshimura M, Minami I, Ikeda U (2016) Allogeneic transplantation of iPS cellderived cardiomyocytes regenerates primate hearts. Nature. 538:388-391. 
158. Shinde AV, Frangogiannis NG (2014) Fibroblasts in myocardial infarction: a role in inflammation and repair. $\mathrm{J} \mathrm{Mol}$ Cell Cardiol. 70:74-82.

159. Sidhu K, Kim J, Chayosumrit M, Dean S, Sachdev P (2012) Alginate microcapsule as a 3D platform for propagation and differentiation of human embryonic stem cells (hESC) to different lineages. J Vis Exp.

160. Siti-Ismail N, Bishop AE, Polak JM, Mantalaris A (2008) The benefit of human embryonic stem cell encapsulation for prolonged feeder-free maintenance.

Biomaterials. 29:3946-52.

161. Slinker BK, Wu Y, Green HW, 3rd, Kirkpatrick RD, Campbell KB (2000) Overall cardiac functional effect of positive inotropic drugs with differing effects on relaxation. J Cardiovasc Pharmacol. 36:1-13.

162. Somers A, Jean JC, Sommer CA, Omari A, Ford CC, Mills JA, Ying L, Sommer AG, Jean JM, Smith BW, Lafyatis R, Demierre MF, Weiss DJ, French DL, Gadue P, Murphy GJ, Mostoslavsky G, Kotton DN (2010) Generation of transgenefree lung disease-specific human induced pluripotent stem cells using a single excisable lentiviral stem cell cassette. Stem Cells. 28:1728-40.

163. Soong PL, Tiburcy M, Zimmermann WH (2012) Cardiac differentiation of human embryonic stem cells and their assembly into engineered heart muscle. Curr Protoc Cell Biol. 1002.

164. Sourisseau M, Goldman O, He W, Gori JL, Kiem HP, Gouon-Evans V, Evans MJ (2013) Hepatic cells derived from induced pluripotent stem cells of pigtail macaques support hepatitis C virus infection. Gastroenterology. 145:966-969 e7.

165. Streckfuss-Bomeke K, Wolf F, Azizian A, Stauske M, Tiburcy M, Wagner S, Hubscher D, Dressel R, Chen S, Jende J, Wulf G, Lorenz V, Schon MP, Maier LS, Zimmermann WH, Hasenfuss G, Guan K (2013) Comparative study of humaninduced pluripotent stem cells derived from bone marrow cells, hair keratinocytes, and skin fibroblasts. Eur Heart J. 34:2618-29. 
166. Suarez-Alvarez B, Rodriguez RM, Calvanese V, Blanco-Gelaz MA, Suhr ST, Ortega F, Otero J, Cibelli JB, Moore H, Fraga MF, Lopez-Larrea C (2010) Epigenetic mechanisms regulate $\mathrm{MHC}$ and antigen processing molecules in human embryonic and induced pluripotent stem cells. PLoS One. 5:e10192.

167. Swann K, Yu Y (2008) The dynamics of calcium oscillations that activate mammalian eggs. Int J Dev Biol. 52:585-94.

168. Takahashi K, Yamanaka S (2006) Induction of pluripotent stem cells from mouse embryonic and adult fibroblast cultures by defined factors. Cell. 126:663-76.

169. Takahashi K, Tanabe K, Ohnuki M, Narita M, Ichisaka T, Tomoda K, Yamanaka S (2007) Induction of pluripotent stem cells from adult human fibroblasts by defined factors. Cell. 131:861-72.

170. Tamargo J, Caballero R, Gomez R, Barana A, Amoros I, Delpon E (2009) Investigational positive inotropic agents for acute heart failure. Cardiovasc Hematol Disord Drug Targets. 9:193-205.

171. Tan $Y$, Han $P$, Gu Q, Chen G, Wang L, Ma R, Wu J, Feng C, Zhang Y, Wang L, Hu B, Li W, Hao J, Zhou Q (2016) Generation of Clinical-grade Functional Cardiomyocytes from Human Embryonic Stem Cells in Chemically Defined Conditions. J Tissue Eng Regen Med.

172. Taylor CJ, Bolton EM, Pocock S, Sharples LD, Pedersen RA, Bradley JA (2005) Banking on human embryonic stem cells: estimating the number of donor cell lines needed for HLA matching. Lancet. 366:2019-25.

173. Taylor CJ, Peacock S, Chaudhry AN, Bradley JA, Bolton EM (2012) Generating an iPSC bank for HLA-matched tissue transplantation based on known donor and recipient HLA types. Cell Stem Cell. 11:147-52.

174. Terrovitis JV, Smith RR, Marban E (2010) Assessment and optimization of cell engraftment after transplantation into the heart. Circ Res. 106:479-94. 
175. Thomson JA, Kalishman J, Golos TG, Durning M, Harris CP, Becker RA, Hearn JP (1995) Isolation of a primate embryonic stem cell line. Proc Natl Acad Sci U S A. 92:7844-8.

176. Thomson JA, Itskovitz-Eldor J, Shapiro SS, Waknitz MA, Swiergiel JJ, Marshall VS, Jones JM (1998) Embryonic stem cell lines derived from human blastocysts. Science. 282:1145-7.

177. Tian S, Liu Q, Gnatovskiy L, Ma PX, Wang Z (2015) Heart Regeneration with Embryonic Cardiac Progenitor Cells and Cardiac Tissue Engineering. J Stem Cell Transplant Biol. 1.

178. Tiburcy M, Meyer T, Soong PL, Zimmermann WH (2014) Collagen-based engineered heart muscle. Methods Mol Biol. 1181:167-76.

179. Tiburcy M, Zimmermann WH (2014) Modeling myocardial growth and hypertrophy in engineered heart muscle. Trends Cardiovasc Med. 24:7-13.

180. Tiburcy M, Hudson JE, Balfanz P, Schlick SF, Meyer T, Chang Liao ML, Levent E, Raad F, Zeidler S, Wingender E, Riegler J, Wang M, Gold JD, Kehat I, Wettwer E, Ravens U, Dierickx P, van Laake L, Goumans MJ, Khadjeh S, Toischer K, Hasenfuss G, Couture LA, Unger A, Linke WA, Araki T, Neel B, Keller G, Gepstein L, Wu JC, Zimmermann WH (2017) Defined Engineered Human Myocardium with Advanced Maturation for Applications in Heart Failure Modelling and Repair. Circulation.

181. Tohyama S, Hattori F, Sano M, Hishiki T, Nagahata $Y$, Matsuura T, Hashimoto H, Suzuki T, Yamashita H, Satoh Y, Egashira T, Seki T, Muraoka N, Yamakawa H, Ohgino Y, Tanaka T, Yoichi M, Yuasa S, Murata M, Suematsu M, Fukuda K (2013) Distinct metabolic flow enables large-scale purification of mouse and human pluripotent stem cell-derived cardiomyocytes. Cell Stem Cell. 12:127-37.

182. Tomioka I, Maeda T, Shimada H, Kawai K, Okada Y, Igarashi H, Oiwa R, Iwasaki T, Aoki M, Kimura T, Shiozawa S, Shinohara H, Suemizu H, Sasaki E, 
Okano H (2010) Generating induced pluripotent stem cells from common marmoset (Callithrix jacchus) fetal liver cells using defined factors, including Lin28. Genes Cells. 15:959-69.

183. Trounson A, Anderiesz C, Jones $G$ (2001) Maturation of human oocytes in vitro and their developmental competence. Reproduction. 121:51-75.

184. Turovets N, Semechkin A, Kuzmichev L, Janus J, Agapova L, Revazova E (2011) Derivation of human parthenogenetic stem cell lines. Methods Mol Biol. 767:37-54.

185. van den Borne SW, Diez J, Blankesteijn WM, Verjans J, Hofstra L, Narula J (2010) Myocardial remodeling after infarction: the role of myofibroblasts. Nat Rev Cardiol. 7:30-7.

186. van der Spoel TI, Jansen of Lorkeers SJ, Agostoni P, van Belle E, Gyongyosi M, Sluijter JP, Cramer MJ, Doevendans PA, Chamuleau SA (2011) Human relevance of pre-clinical studies in stem cell therapy: systematic review and metaanalysis of large animal models of ischaemic heart disease. Cardiovasc Res. 91:649-58.

187. VandeVoort CA, Leibo SP, Tarantal AF (2003) Improved collection and developmental competence of immature macaque oocytes. Theriogenology. 59:699707.

188. VandeVoort CA, Mtango NR, Midic U, Latham KE (2015) Disruptions in follicle cell functions in the ovaries of rhesus monkeys during summer. Physiol Genomics. 47:102-12.

189. Vliegen HW, van der Laarse A, Cornelisse CJ, Eulderink F (1991) Myocardial changes in pressure overload-induced left ventricular hypertrophy. A study on tissue composition, polyploidization and multinucleation. Eur Heart J. 12:488-94. 
190. Vrana KE, Hipp JD, Goss AM, McCool BA, Riddle DR, Walker SJ, Wettstein PJ, Studer LP, Tabar V, Cunniff K, Chapman K, Vilner L, West MD, Grant KA, Cibelli JB (2003) Nonhuman primate parthenogenetic stem cells. Proc Natl Acad Sci U S A. 100 Suppl 1:11911-6.

191. Weaver ME, Pantely GA, Bristow JD, Ladley HD (1986) A quantitative study of the anatomy and distribution of coronary arteries in swine in comparison with other animals and man. Cardiovasc Res. 20:907-17.

192. Wei K, Serpooshan V, Hurtado C, Diez-Cunado M, Zhao M, Maruyama S, Zhu W, Fajardo G, Noseda M, Nakamura K, Tian X, Liu Q, Wang A, Matsuura Y, Bushway P, Cai W, Savchenko A, Mahmoudi M, Schneider MD, van den Hoff MJ, Butte MJ, Yang PC, Walsh K, Zhou B, Bernstein D, Mercola M, Ruiz-Lozano P (2015) Epicardial FSTL1 reconstitution regenerates the adult mammalian heart. Nature. 525:479-85.

193. Weinberger F, Breckwoldt K, Pecha S, Kelly A, Geertz B, Starbatty J, Yorgan $\mathrm{T}$, Cheng KH, Lessmann K, Stolen T, Scherrer-Crosbie M, Smith G, Reichenspurner $H$, Hansen A, Eschenhagen $T$ (2016) Cardiac repair in guinea pigs with human engineered heart tissue from induced pluripotent stem cells. Sci Trans/ Med. 8:363ra148.

194. Wendel JS, Ye L, Tao R, Zhang J, Zhang J, Kamp TJ, Tranquillo RT (2015) Functional Effects of a Tissue-Engineered Cardiac Patch From Human Induced Pluripotent Stem Cell-Derived Cardiomyocytes in a Rat Infarct Model. Stem Cells Trans/ Med. 4:1324-32.

195. Weng Z, Kong CW, Ren L, Karakikes I, Geng L, He J, Chow MZ, Mok CF, Keung W, Chow H, Leung AY, Hajjar RJ, Li RA, Chan CW (2014) A simple, costeffective but highly efficient system for deriving ventricular cardiomyocytes from human pluripotent stem cells. Stem Cells Dev. 23:1704-16.

196. White FC, Roth DM, Bloor CM (1986) The pig as a model for myocardial ischemia and exercise. Lab Anim Sci. 36:351-6. 
197. WHO WHO. Cardiovascular diseases (CVDs) Fact Sheet. 2016.

198. Wiegerinck RF, Cojoc A, Zeidenweber CM, Ding G, Shen M, Joyner RW, Fernandez JD, Kanter KR, Kirshbom PM, Kogon BE, Wagner MB (2009) Force frequency relationship of the human ventricle increases during early postnatal development. Pediatr Res. 65:414-9.

199. Wilson JL, Najia MA, Saeed R, McDevitt TC (2014) Alginate encapsulation parameters influence the differentiation of microencapsulated embryonic stem cell aggregates. Biotechnol Bioeng. 111:618-31.

200. Winston NJ (1997) Stability of cyclin B protein during meiotic maturation and the first mitotic cell division in mouse oocytes. Biol Cell. 89:211-9.

201. Wobus AM, Wallukat G, Hescheler J (1991) Pluripotent mouse embryonic stem cells are able to differentiate into cardiomyocytes expressing chronotropic responses to adrenergic and cholinergic agents and $\mathrm{Ca} 2+$ channel blockers. Differentiation. 48:173-82.

202. Wu Y, Zhang Y, Mishra A, Tardif SD, Hornsby PJ (2010) Generation of induced pluripotent stem cells from newborn marmoset skin fibroblasts. Stem Cell Res. 4:180-8.

203. Wunderlich S, Kircher M, Vieth B, Haase A, Merkert S, Beier J, Gohring G, Glage S, Schambach A, Curnow EC, Paabo S, Martin U, Enard W (2014) Primate iPS cells as tools for evolutionary analyses. Stem Cell Res. 12:622-9.

204. Xu C, Police S, Hassanipour M, Li Y, Chen Y, Priest C, O'Sullivan C, Laflamme MA, Zhu WZ, Van Biber B, Hegerova L, Yang J, Delavan-Boorsma K, Davies A, Lebkowski J, Gold JD (2011) Efficient generation and cryopreservation of cardiomyocytes derived from human embryonic stem cells. Regen Med. 6:53-66.

205. Yang H, Liu Z, Ma Y, Zhong C, Yin Q, Zhou C, Shi L, Cai Y, Zhao H, Wang H, Tang F, Wang Y, Zhang C, Liu XY, Lai D, Jin Y, Sun Q, Li J (2013) Generation of 
haploid embryonic stem cells from Macaca fascicularis monkey parthenotes. Cell Res. 23:1187-200.

206. Yang L, Soonpaa MH, Adler ED, Roepke TK, Kattman SJ, Kennedy M, Henckaerts E, Bonham K, Abbott GW, Linden RM, Field LJ, Keller GM (2008) Human cardiovascular progenitor cells develop from a KDR+ embryonic-stem-cellderived population. Nature. 453:524-8.

207. Ye L, Zimmermann WH, Garry DJ, Zhang J (2013) Patching the heart: cardiac repair from within and outside. Circ Res. 113:922-32.

208. Yin JY, Tang Q, Zhai LL, Zhou LY, Qian J, Lin J, Wen XM, Zhou JD, Zhang YY, Zhu XW, Deng ZQ (2015) High expression of OCT4 is frequent and may cause undesirable treatment outcomes in patients with acute myeloid leukemia. Tumour Biol. 36:9711-6.

209. Yu J, Vodyanik MA, Smuga-Otto K, Antosiewicz-Bourget J, Frane JL, Tian S, Nie J, Jonsdottir GA, Ruotti V, Stewart R, Slukvin, II, Thomson JA (2007) Induced pluripotent stem cell lines derived from human somatic cells. Science. 318:1917-20.

210. Zeineddine D, Papadimou E, Chebli K, Gineste M, Liu J, Grey C, Thurig S, Behfar A, Wallace VA, Skerjanc IS, Puceat M (2006) Oct-3/4 dose dependently regulates specification of embryonic stem cells toward a cardiac lineage and early heart development. Dev Cell. 11:535-46.

211. Zeineddine D, Hammooud AA, Mortada M, Boeuf $\mathrm{H}$ (2014) The Oct4 protein: more than a magic stemness marker. American Journal of Stem Cells. 3:74-82.

212. Zeng L, Hu Q, Wang X, Mansoor A, Lee J, Feygin J, Zhang G, Suntharalingam P, Boozer S, Mhashilkar A, Panetta CJ, Swingen C, Deans R, From $\mathrm{AH}$, Bache RJ, Verfaillie CM, Zhang J (2007) Bioenergetic and functional consequences of bone marrow-derived multipotent progenitor cell transplantation in hearts with postinfarction left ventricular remodeling. Circulation. 115:1866-75. 
213. Zhang $H$, Song $P$, Tang $Y$, Zhang $X L$, Zhao SH, Wei YJ, Hu SS (2007) Injection of bone marrow mesenchymal stem cells in the borderline area of infarcted myocardium: heart status and cell distribution. J Thorac Cardiovasc Surg. 134:123440.

214. Zhang X, Cao H, Bai S, Huo W, Ma Y (2017) Differentiation and characterization of rhesus monkey atrial and ventricular cardiomyocytes from induced pluripotent stem cells. Stem Cell Res. 20:21-29.

215. Zhong B, Trobridge GD, Zhang X, Watts KL, Ramakrishnan A, Wohlfahrt M, Adair JE, Kiem HP (2011) Efficient generation of nonhuman primate induced pluripotent stem cells. Stem Cells Dev. 20:795-807.

216. Zhong W, Mao S, Tobis S, Angelis E, Jordan MC, Roos KP, Fishbein MC, de Alboran IM, MacLellan WR (2006) Hypertrophic growth in cardiac myocytes is mediated by Myc through a Cyclin D2-dependent pathway. EMBO J. 25:3869-79.

217. Zhu FF, Zhang PB, Zhang DH, Sui X, Yin M, Xiang TT, Shi Y, Ding MX, Deng $H$ (2011) Generation of pancreatic insulin-producing cells from rhesus monkey induced pluripotent stem cells. Diabetologia. 54:2325-36.

218. Zhu W, Gao L, Zhang J (2017) Pluripotent Stem Cell Derived Cardiac Cells for Myocardial Repair. J Vis Exp.

219. Zimmermann W-H, Melnychenko I, Wasmeier G, Didie M, Naito H, Nixdorff U, Hess A, Budinsky L, Brune K, Michaelis B, Dhein S, Schwoerer A, Ehmke H, Eschenhagen T (2006) Engineered heart tissue grafts improve systolic and diastolic function in infarcted rat hearts. Nat Med. 12:452-458.

220. Zimmermann WH, Fink C, Kralisch D, Remmers U, Weil J, Eschenhagen $T$ (2000) Three-dimensional engineered heart tissue from neonatal rat cardiac myocytes. Biotechnology and Bioengineering. 68:106-114. 
221. Zimmermann WH, Schneiderbanger K, Schubert P, Didie M, Munzel F, Heubach JF, Kostin S, Neuhuber WL, Eschenhagen T (2002) Tissue engineering of a differentiated cardiac muscle construct. Circ Res. 90:223-30.

222. Zimmermann WH, Eschenhagen $T$ (2003) Cardiac tissue engineering for replacement therapy. Heart Fail Rev. 8:259-69. 


\section{Appendix}

\section{A1: Reagents}

Accutase digestion solution

Accutase solution (SCR005; Millipore)

$0.125 \%$ Trypsin (1:20 dilution from Trypsin $2.5 \%$ stock [Gibco, 15090-046])

$20 \mu \mathrm{g} / \mathrm{ml}$ DNase I

\section{Activin A stock solution}

Dissolve Activin A (338-AC, R\&D systems) according to manufactures protocol to obtain a stock concentration of $10 \mu \mathrm{g} / \mathrm{ml}$. Aliquot into sterile $1 \mathrm{ml}$ tubes and store at $20^{\circ} \mathrm{C}$.

\section{FGF-2 stock solution}

Dissolve FGF-2 (130-093-841; Stemgent) according to manufacturer's protocol to obtain a stock concentration of $10 \mu \mathrm{g} / \mathrm{ml}$. Aliquot into sterile microfuge tubes and store at $-20^{\circ} \mathrm{C}$. Aliquot into sterile $1 \mathrm{ml}$ tubes and store at $-20^{\circ} \mathrm{C}$.

\section{BMP4 stock solution}

Dissolve BMP4 (314-BP, R\&D systems) according to manufactures protocol to obtain a stock concentration of $10 \mu \mathrm{g} / \mathrm{ml}$. Aliquot into sterile $1 \mathrm{ml}$ tubes and store at -20 ${ }^{\circ} \mathrm{C}$.

\section{CHIR stock solution}

Dissolve CHIR (04-0004, Stemgent) in DMSO to obtain a stock concentration of 10 $\mathrm{mmol} / \mathrm{L}$. Aliquot into sterile $1 \mathrm{ml}$ tubes and store at $-20^{\circ} \mathrm{C}$.

\section{IWP4 stock solution}

Dissolve IWP4 (04-0036, Stemgent) in DMSO to obtain a stock concentration of 5 $\mathrm{mmol} / \mathrm{L}$. Aliquot into sterile $1 \mathrm{ml}$ tubes and store at $-20^{\circ} \mathrm{C}$. 


\section{Collagenase I solution}

$100 \mathrm{mg}$ of collagenase I dissolved in $40 \mathrm{ml}$ of 1 X DPBS (containing $\mathrm{Ca}^{2+} / \mathrm{Mg}^{2+}$ ) and $10 \mathrm{ml}$ FBS (10270; Gibco) . Sterile filter (0.22um), aliquot $10 \mathrm{ml}$ into $15 \mathrm{ml}$ tubes and store at $-20^{\circ} \mathrm{C}$.

\section{EDTA Solution $(0.5 \mathrm{mmol} / \mathrm{L})$}

Add $500 \mu \mathrm{l}$ of the $0.5 \mathrm{~mol} / \mathrm{L}$ EDTA stock solution $(\mathrm{pH} 8.0)$, to $500 \mathrm{ml}$ of $1 \mathrm{X}$ PBS 14190; Gibco), containing $0.45 \mathrm{~g} \mathrm{NaCl}$. Sterile filter (0.22 um), aliquot $10 \mathrm{ml}$ into 15 $\mathrm{ml}$ tubes and store at $4{ }^{\circ} \mathrm{C}$ up to 6 months.

Freezing medium

$90 \%$ FBS

$10 \%$ DMSO (276855; Sigma Aldrich)

hFF medium

500 ml DMEM (42430; Gibco)

$88.8 \mathrm{ml} \mathrm{FBS}$

$3 \mathrm{ml} \mathrm{P} / \mathrm{S}$

\section{hES medium}

$500 \mathrm{ml}$ KO-DMEM(10829-018, Gibco)

$128.2 \mathrm{ml} \mathrm{KOSR}$ (10828028, Gibco)

$6.4 \mathrm{ml}$ L-glutamine

$6.4 \mathrm{ml}$ MEM NEAA

Add $10 \mu \mathrm{l}$ of -2FGF stock solution into $10 \mathrm{ml}$ of hES medium (final FGF-2 concentration: $10 \mathrm{ng} / \mathrm{ml}$ ).

\section{TeSR ${ }^{\mathrm{TM}}{ }_{-} \mathrm{E} 8^{\mathrm{TM}}$ medium}

Make up TeSR ${ }^{\text {TM }}$-E8 medium (05940; StemCell Technologies) according to manufacturer protocol, including $1 \% \mathrm{P} / \mathrm{S}$. 


\section{X DMEM}

669 mg DMEM powder (52100-039; Gibco) dissolved in $5 \mathrm{ml}$ sterile $\mathrm{H}_{2} 0$.

Filter the solution through a $0.22 \mu \mathrm{m}$ syringe filter. Store at $4{ }^{\circ} \mathrm{C}$ for $1-2$ months.

\section{$\underline{2 X \text { DMEM }}$}

$1 \mathrm{ml} \quad 10 X$ DMEM

$120 \mathrm{ml} \quad$ FBS

$100 \mu \mathrm{l} \quad$ L-glutamine

$100 \mu \mathrm{l} \quad \mathrm{P} / \mathrm{S}$

Volume adjusted to $5 \mathrm{ml}$ with $\mathrm{dd}_{2} \mathrm{O}$.

A2: Serum free basal media

\begin{tabular}{|c|c|c|c|}
\hline $\begin{array}{c}\text { Serum free basal medium } \\
\text { (SFBM) }\end{array}$ & Volume & Vendor & Order No. \\
\hline RPMI 1640 plus Glutamax & & Gibco & $61870-044$ \\
\hline B27 plus insulin & $2 \%$ & Gibco & $17504-044$ \\
\hline Non-essential amino acids & $1 \%$ & Gibco & $11140-035$ \\
\hline Ascorbic acid & $200 \mu \mathrm{mol} / \mathrm{L}$ & Sigma & A8960 \\
\hline Penicillin & $100 \mathrm{U} / \mathrm{ml}$ & Gibco & $15140-122$ \\
\hline Streptomycin & $100 \mu \mathrm{g} / \mathrm{ml}$ & Gibco & $15140-122$ \\
\hline FGF - 2 & $9 \mathrm{ng} / \mathrm{ml}$ & R\&D Systems & $338-$ AC \\
\hline Supplements & $5 \mathrm{ng} / \mathrm{ml}$ & Stemgent & $130-093-841$ \\
\hline & & Vendor & Cat. No. \\
\hline & & & \\
\hline & & & \\
\hline
\end{tabular}




\begin{tabular}{|c|c|c|c|}
\hline BMP4 & $5 \mathrm{ng} / \mathrm{ml}$ & R\&D Systems & 314-BP \\
\hline CHIR99021 & $1 \mu \mathrm{mol} / \mathrm{L}$ & Stemgent & $04-0004$ \\
\hline IWP4 & $5 \mu \mathrm{mol} / \mathrm{L}$ & Stemgent & $04-0036 \mathrm{C}$ \\
\hline
\end{tabular}

A3: Lactate selection medium

\begin{tabular}{|c|c|c|c|}
\hline Lactate selection medium & Concentration & Vendor & Order No. \\
\hline $\begin{array}{c}\text { RPMl w/o glucose } \\
\text { w/o glutamine }\end{array}$ & Gibco & 11879020 \\
\hline Sodium lactate & $2.2 \mathrm{mmol} / \mathrm{L}$ & Sigma-Aldrich & 71723 \\
\hline $50 \mathrm{mM}$ 2-mercaptoethanol & $100 \mu \mathrm{mol} / \mathrm{L}$ & ThermoFisher & 31350010 \\
\hline Penicillin & $100 \mathrm{U} / \mathrm{ml}$ & Gibco & $15140-122$ \\
\hline Streptomycin & $100 \mu \mathrm{g} / \mathrm{ml}$ & Gibco & $15140-122$ \\
\hline
\end{tabular}

A4: Serum free maturation medium

\begin{tabular}{|c|c|c|c|}
\hline & Concentration & Vendor & Order No. \\
\hline Iscove-DMEM & & Gibco & $31980-022$ \\
\hline B27 minus insulin & $4 \%$ & Gibco & A418950-01 \\
\hline Non-essential amino acids & $1 \%$ & Gibco & $11140-035$ \\
\hline Ascorbic acid & $200 \mu \mathrm{mol} / \mathrm{ml}$ & Sigma-Aldrich & A8960 \\
\hline IGF-1 & $100 \mathrm{ng} / \mathrm{ml}$ & Peprotech & AF-100-11 \\
\hline
\end{tabular}




\begin{tabular}{|c|c|c|c|}
\hline FGF-2 & $10 \mathrm{ng} / \mathrm{ml}$ & Stemgent & $130-093-841$ \\
\hline VEGF $_{165}$ & $5 \mathrm{ng} / \mathrm{ml}$ & Peprotech & AF-100-20 \\
\hline Penicillin & $100 \mathrm{U} / \mathrm{ml}$ & Gibco & $15140-122$ \\
\hline Streptomycin & $100 \mu \mathrm{g} / \mathrm{ml}$ & Gibco & $15140-122$ \\
\hline Supplement & Concentration & Vendor & Order No. \\
\hline TGF- $\beta$ & $5 \mathrm{ng} / \mathrm{ml}$ & Peprotech & AF-100-21C \\
\hline
\end{tabular}

A5: Blocking buffer

\begin{tabular}{|c|c|c|c|}
\hline 1X PBS (0.05 M, pH 7.4) & $500 \mathrm{ml}$ & Gibco & $14190-094$ \\
\hline Fetal Bovine Serum & $25 \mathrm{ml}$ & Gibco & $10370-106$ \\
\hline Bovine Serum Albumin (BSA) & 5 grams & Sigma-Aldrich & A3311 \\
\hline Triton $-X 100$ & $2.5 \mathrm{ml}$ & Sigma-Aldrich & T8787 \\
\hline
\end{tabular}

A6: Immunofluorescence antibodies

\begin{tabular}{|c|c|c|c|}
\hline Primary Antibody & Dilution & Vendor & Order No./Clone \\
\hline Anti - $\alpha$-actinin & $1: 1000$ & Sigma-Aldrich & A7811 \\
\hline Anti - MLC2v & $1: 500$ & Synaptic Systems & 310003 \\
\hline Anti - MLC2a & $1: 500$ & Synaptic Systems & $56 F 5$ \\
\hline Anti - Tbx-5 & $1: 25$ & Sigma-Aldrich & HPA008786 \\
\hline
\end{tabular}




\begin{tabular}{|c|c|c|c|}
\hline Anti - CX43 & $1: 250$ & BD Biosystems & 610062 \\
\hline Secondary Antibody & Dilution & Vendor & Order No./Clone \\
\hline $\begin{array}{c}\text { Goat anti mouse Alexa Fluor } \\
488\end{array}$ & $1: 1000$ & ThermoFisher & A-11001 \\
\hline $\begin{array}{c}\text { Goat anti mouse Alexa Fluor } \\
633\end{array}$ & $1: 1000$ & ThermoFisher & A-21052 \\
\hline $\begin{array}{c}\text { Goat anti rabbit Alexa Fluor 633 } \\
\text { Goat anti rabbit Alexa Fluor 546 }\end{array}$ & $1: 1000$ & ThermoFisher & A-21070 \\
\hline
\end{tabular}

A7: Operation anesthesia

Rhesus 2551

\begin{tabular}{|c|c|c|c|c|c|}
\hline Operation & $\begin{array}{c}\text { Weight } \\
\mathbf{( k g )}\end{array}$ & $\begin{array}{c}\text { Ketamine } \\
\mathbf{( 7 ~} \mathbf{~ m g} / \mathbf{k g}) \\
\text { (total } \mathbf{~ m l})\end{array}$ & $\begin{array}{c}\text { Medetomidine } \\
\mathbf{( 0 . 0 4} \mathbf{~ m g} / \mathbf{k g}) \\
\text { (total } \mathbf{~ m l})\end{array}$ & $\begin{array}{c}\text { Metamizole } \\
\mathbf{( 2 0 - 5 0} \\
\mathbf{m g} / \mathbf{k g}) \\
(\text { total } \mathbf{~ m l})\end{array}$ & $\begin{array}{c}\text { Butorphanol } \\
\mathbf{( 0 . 0 1 - 0 . 0 2} \\
\mathbf{m g} / \mathbf{k g}) \\
\text { (total } \mathbf{~ m l})\end{array}$ \\
\hline Ultrasound & 5.7 & 0.5 & 0.6 & & \\
\hline $\begin{array}{c}\text { Follicle } \\
\text { aspiration }\end{array}$ & 5.1 & 0.35 & 0.2 & 0.2 & 0.16 \\
\hline Ovariectomy & 5.8 & 1.32 & 0.5 & 0.1 & 0.5 \\
\hline
\end{tabular}


Rhesus 2506

\begin{tabular}{|c|c|c|c|c|c|}
\hline Operation & $\begin{array}{c}\text { Weight } \\
\text { (kg) }\end{array}$ & $\begin{array}{l}\text { Ketamine } \\
(7 \mathrm{mg} / \mathrm{kg}) \\
\text { (total } \mathrm{ml})\end{array}$ & $\begin{array}{c}\text { Medetomidine } \\
\text { (0.04 mg/kg) } \\
\text { (total ml) }\end{array}$ & $\begin{array}{c}\text { Metamizole } \\
(20-50 \\
\mathrm{mg} / \mathrm{kg}) \\
\text { (total ml) }\end{array}$ & $\begin{array}{c}\text { Butorphanol } \\
\text { (0.01-0.02 } \\
\mathrm{mg} / \mathrm{kg}) \\
\text { (total } \mathrm{ml})\end{array}$ \\
\hline Ultrasound & 7.4 & 0.6 & 0.35 & & \\
\hline $\begin{array}{c}\text { Follicle } \\
\text { aspiration }\end{array}$ & 7.3 & 0.55 & 0.03 & 0.2 & 0.2 \\
\hline Ovariectomy & 7.4 & 0.6 & 0.35 & 0.7 & 0.14 \\
\hline
\end{tabular}

Rhesus 2500

\begin{tabular}{|c|c|c|c|c|c|}
\hline Operation & $\begin{array}{c}\text { Weight } \\
\text { (kg) }\end{array}$ & $\begin{array}{l}\text { Ketamine } \\
(7 \mathrm{mg} / \mathrm{kg}) \\
\text { (total } \mathrm{ml})\end{array}$ & $\begin{array}{c}\text { Medetomidine } \\
(0.04 \mathrm{mg} / \mathrm{kg}) \\
\text { (total } \mathrm{ml})\end{array}$ & $\begin{array}{c}\text { Metamizole } \\
(20-50 \\
\mathrm{mg} / \mathrm{kg}) \\
\text { (total } \mathrm{ml})\end{array}$ & $\begin{array}{c}\text { Butorphanol } \\
\text { (0.01-0.02 } \\
\mathrm{mg} / \mathrm{kg}) \\
\text { (total ml) }\end{array}$ \\
\hline Ultrasound & 7.6 & 0.5 & 0.3 & & \\
\hline $\begin{array}{l}\text { Follicle aspi- } \\
\text { ration }\end{array}$ & 6.5 & 0.5 & 0.3 & 0.2 & \\
\hline Ovariectomy & 7.5 & 0.7 & 0.3 & 0.2 & 0.1 \\
\hline
\end{tabular}

Rhesus 2483

\begin{tabular}{|c|c|c|c|c|c|}
\hline Operation & $\begin{array}{c}\text { Weight } \\
\text { (kg) }\end{array}$ & $\begin{array}{l}\text { Ketamine } \\
(7 \mathrm{mg} / \mathrm{kg}) \\
\text { (total } \mathrm{ml})\end{array}$ & $\begin{array}{c}\text { Medetomidine } \\
\text { (0.04 mg/kg) } \\
\text { (total ml) }\end{array}$ & $\begin{array}{c}\text { Metamizole } \\
(20-50 \\
\mathrm{mg} / \mathrm{kg}) \\
\text { (total } \mathrm{ml})\end{array}$ & $\begin{array}{c}\text { Butorphanol } \\
\text { (0.01-0.02 } \\
\mathrm{mg} / \mathrm{kg}) \\
\text { (total } \mathrm{ml})\end{array}$ \\
\hline $\begin{array}{c}\text { Follicle } \\
\text { aspiration }\end{array}$ & 5.1 & 0.35 & 0.2 & 0.2 & 0.16 \\
\hline Ovariectomy & 4.9 & 0.65 & 0.4 & 0.35 & 0.1 \\
\hline
\end{tabular}


Rhesus 2616

\begin{tabular}{|c|c|c|c|c|c|}
\hline Operation & $\begin{array}{c}\text { Weight } \\
\text { (kg) }\end{array}$ & $\begin{array}{l}\text { Ketamine } \\
(7 \mathrm{mg} / \mathrm{kg}) \\
\text { (total } \mathrm{ml})\end{array}$ & $\begin{array}{c}\text { Medetomidine } \\
(0.04 \mathrm{mg} / \mathrm{kg}) \\
\text { (total } \mathrm{ml})\end{array}$ & $\begin{array}{c}\text { Metamizole } \\
(20-50 \\
\mathrm{mg} / \mathrm{kg}) \\
\text { (total } \mathrm{ml})\end{array}$ & $\begin{array}{c}\text { Butorphanol } \\
\text { (0.01-0.02 } \\
\mathrm{mg} / \mathrm{kg}) \\
\text { (total ml) }\end{array}$ \\
\hline Ultrasound & 6.2 & 0.65 & 0.2 & & \\
\hline $\begin{array}{c}\text { Follicle } \\
\text { aspiration }\end{array}$ & 5.2 & 0.65 & 0.2 & 0.2 & 0.16 \\
\hline Ovariectomy & 6.2 & 0.92 & 0.25 & 0.4 & 0.22 \\
\hline
\end{tabular}

A8: In vitro maturation medium

\begin{tabular}{|c|c|c|c|}
\hline & Concentration & Vendor & Order no. \\
\hline $\begin{array}{c}\text { hES medium } \\
\text { Appendix A1) }\end{array}$ & & & \\
\hline Ascorbic Acid & $50 \mu \mathrm{g} / \mathrm{ml}$ & Sigma-Aldrich & A8960 \\
\hline Sodium Lactate & $10 \mathrm{mmol} / \mathrm{L}$ & Sigma-Aldrich & 71723 \\
\hline hCG & $10 \mathrm{IU} / \mathrm{ml}$ & Merck Serono & Ovitrelle; $250 \mathrm{mg}$ \\
\hline hFSH & $10 \mathrm{IU} / \mathrm{ml}$ & Merck Serono & Gonal F; 75 IU \\
\hline Sodium pyruvate & $0.5 \mathrm{mmol} / \mathrm{l}$ & Gibco & 11360070 \\
\hline Penicillin & $50 \mathrm{U} / \mathrm{ml}$ & Gibco & $15140-122$ \\
\hline Streptomycin & $50 \mu \mathrm{g} / \mathrm{ml}$ & Gibco & $15140-122$ \\
\hline
\end{tabular}




\section{Curriculum vitae}

Name:

Brian T. Golat, MSc

Date of Birth:

2 August 1978

Place of Birth:

Port Huron, Michigan, United States of America

Nationality

American

\section{Education:}

$11 / 2012$ - present

Doctoral candidate

Institute of Pharmacology and Toxicology,

University Medical Centre Göttingen, Germany,

PhD program "Molecular Medicine"

$0 / 2011-12 / 2006$

Master of Medical Sciences

College of Medicine,

Department of Anatomy,

University of South Florida, Tampa, Florida, USA,

10/2008 - 12/2002 Bachelor of Science

University of Central Florida, Orlando, Florida, USA

\section{Participation in conferences:}

06. - 08. October 2016: DGK Herztage 2016, Berlin, Germany poster presentation: Comparative Analysis of Rhesus Macaque Stem Cells for use in Cardiac Tissue Engineering.

08. - 10. October 2015: DGK Herbsttagung, Berlin, Germany, poster presentation: Engineered Heart Muscle from Rhesus Macaque Induced Pluripotent Stem Cell-Derived Cardiomyocytes. 3. Prize Hans-Jürgen-BretschneiderPosterpreis des Basic Science Meetings.

17. - 19. September 2015: 2. Young DZHK Symposium, Brandenburg, Germany, poster presentation_Development of a scalable suspension and cardiac differ- 
entiation culture of Rhesus macaque induced pluripotent stem cells for use in engineered heart muscle. 